\title{
T H
}

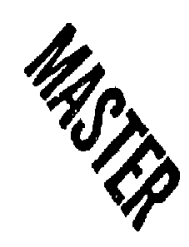

HYDROLOGIC PROPERTIES

O F

S H A I E

AND RELATED ARGILLACEOUC ROCKS

Report prepared under

Contract: LiJ 590-5909

By A, N. Moiseyev,

Department of Geological Sciences

California State University, Hayward

Nov. 15,1979 


\section{FOREWORD}

This report presents the results of a bibliographic search which was designed to collect information on the hydrologic properties of shale and related argillaceous rocks. Its prime objective was the gathering of numericai data to serve as reference for studies into the use of such rocks as repositories for radioactive wastes. The tables in which these data have been compiled thus represent the main part of this report.

During the search additional information was uncovered and judged to be relevant to the scope of the project. Mathematical relationships between the various rock parameters (porosity, permeability, density, depth, etc.) were thought to be useful for making estimates whenever data is incomplete and for designing mathenatical models of repositories. Likewise, it was decided that possible relationships between shale mineralogy and hydrologic behavior, though poorly backed by numerical data, should be montioned mainly as reference for future search. Finaliy, it was deemed that the numerical data would be made more practical if supported by 3 few general definitions and regional geologic information.

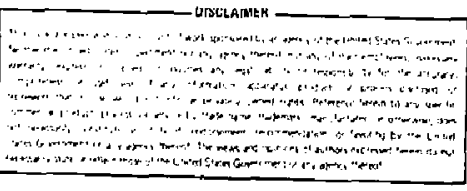


This report does not pretend to cover fuliy the complex hydrologic problems of shale. Rather, the background information is presented in a form to make it understandable for the non-specialist. Probably, most of it could be omitted if the report became incorporated into a larger and more specialized document. The bibliographic search was carried out with the intent of covering as wide a spectrum of references as possible over the $21 / 2$ months period allocated to the project. Unavoidably, some references must have been missed, particularly those from reports or periodicals of linited distribution and those from recent publications which have not yet been listed in bibliographic files. Data search was accomplished by two half-time supervised graduate students using the acoessible files of th- libraries at the University of California in Berkeley and the Lawrence Berkeley liaboratory, at the U.S. Geological Survey in Menlo Park and at the California Division of Mines and Geology in San Francisco. 
Page

I. INTRODUCTION .................. 1

II. THE GEOLOGIC PROPERTIES OF SHALES . . . . . . 3

1-Definitions ............ 3

2-Mineralogy ............ 6

3-E: vironments of Deposition . . . . . 10

4-Diagenesis of Shales.....:. . . 12

5-Post Diagenetic Changes ........ 17

6-Major Shales occurrences in the United

States ........... 17

III. THE HYDROLOGIC PROPERTIES OF SHALES . . . . . 21

1-Brief Review of Important Definitions . . 21

2-Mathematical Relationships ...... 25

3-Lithologic parameters........ 30

4-Diagenetic and Post Diagenetic Changes . . 31

IV. THE HYRPOLOGIC PROPERTIES OF SHALES IN THE

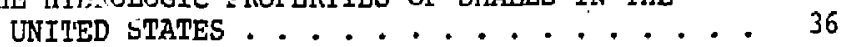

Organization of Data .......... 36

Region 1: Pacific Coast, Great Valley,

Great Basin.......... . 38

Region 2: Rocky Mountains, Colorado

Plateau, and Great plains . . . . . . . 74

Region 3: The Mid-Continent ....... 103

Region 4: The Gulf Coast and the Mississippi

Embayment .............. 120

Region 5: The Appalachian and Great Lakes . 136

Region 6: The Atlantic Coastal Plain and the

Triassic Basins............ 147

V. BIBLIOGRAPHIC REFERENCES .......... 156 


\section{IIST OF FIGURES}

Figure

Page

1. Permeability/Porosity relationships calculated for various mathenatical models 28

2. Effect of ion adsorption upon the permeability of two clay miserals: smectite and kaolinite ............

3. Map showing the location of regions where shale units are found in the United states

4. Map showing the location of the Cambrian Terrigenous Sequence in the Great Basin.

5. Map showing the location of the Eleana Formation (Upper Devonian-Mississippian) in the Great Basin . . . . .....

6. Generalized section across the San Joaquin valley..............

7. Generalized section across the Sacramento valley ...............

8. Stratigraphic relations of the Pierre shale and equivalent rocks .......... 75

9. Structure sections showing typical relationships in the Colorado Plateau and the Rocky Mountains ..........

10. Distribution of Paleozoic structures in the Mid-Continent .......... 104

11. Map showing the distribution of the Chattanooga Shale (Devonian-Mississippian) in the United States..........

12. Sections illustrating structural relationships in the Mid-Continent....... 105

13. Section across the Gulf Coast clastic wedge 121 
LIST OF FIGURES (Continued)

Figure

Page

14. Stratigraphic diagram showing the relationships between the Martinsburg and Chattanooga shales in the AppalachianGreat Iake Region . . . . . . . . 137

15. Generalized structural sections across the Appalachians and the Atlantic Coastal plain.............. 148

16. Section showing detailed structure of a Triassic Basin .. . . . . . . . . 148 


\section{LIST OF TABLES}

\section{Table}

\section{Page}

4-1-a. Sumnary of Paleozoic rocks in the Great Basin.......... 45

4-1-b. Summary of rock units in the San Joaquin valley area, California...... 46

4-1-c. Summary of rock units in the California Coast Ranges ......... 48

4-2. Summary of rock units in the Rocky Mountains, Colorado Plateau and Great Plains ......... 78

4-3. Summary of rock units in the MidContinent Region ....... 106

4-4. Summary of rock units in the Gulf coast and the Mississippi Embayment Region . 122

4-5. Sunmary of rock units of the AppalachianGreat Lakes Region ......... 138

4-6. Summary of rork units in the Atlantic Coastal Paain and Triassic Basins Region ............ 149 
IIST OF HYDROLOGIC DATA

Data

Region 1: Pacific Coast, Great Valley, and Great Basin......... 51

Region 2: Rocky Mountains, Colorado Plateau, and Great Plains . . . . . . . 80

Region 3: Mid-Continent Region ..... . . . 112

Region 4: Gulf Coast and Mississippi Embayment . 124

Region 5: Appalachian-Great Lakes Region .... 142

Region 6: Atlantic Coastal Plain and Triassic

Basins ........... 151 
ABSTRACT

This report is the result of a bibliographic study designed primarily to collect nydrolngic data on American clay-rich rocks. In connection with this search the following information was also sought: stratigraphy, environment of deposition, mineralogic composition, and diagenetic changes. The collected numerical data are presented in tables which contain densities, porosities, and/or hydraulic conductivities of approximately 360 samples. Additional data include hydrauljc diffusivities, resistivities, flow rates, and rock strengths. Geologic information suggests that large deposits of shale which may be suited for waste repository belong to all ages and were formed in both marine and continental environments. of the studied units, the most promising are Paleozoic in the eastern half of the country, Mesozoic in the central part, and Cenozoic in the Gulf Coast area and the West. Less widespread units locally present some adaitional possibilities. Mineralogic investigations suggest that the smectite content in rocks snows a decrease in time $170 \%$ in Recent rocks; 358 in pre-Mesozoic rocks). Because of this predorifinance of smectite in younger rocks, the modeling of repositories in post-Paleozoic formations might require knowledge of additional and poorly known parameters. 
Results of investigations into the mathematical relationships between porosity and permeability for nydraulic conductivity) suggest that in situ permeabilities could be estimated from sonic logs and fluid pressure changes at depth.

This work was supported by the United States Nuclear Regulatory Commission under a Memorandum of Underatanding with the United States Department of Energy. 


\section{SUMMARY}

The investigation described in this report was carried out to obtain numerical data which could be used for aszessiny possible repositories of radioactive wastes in shale. The gathering of information was accomplished through a bibliographic search of the files of the University of California at Berkeley, of the Lawrence Berkeley Laboratory, of the U.S. Geological Survey in Menlo Park, and of the Cali.:ornia Division of Mines and Geology in San Francisco.

The search was completed between June 13 and september 1, 1979. I'wo graduate students from the California State University, Haywara, each working half time were directed to collect data from references listed in the GEOREF computer file and additional sources furnished by the principal investigator, Weekly meetings were organized during which the students reported their findings, discussed their problems, and receivet new instructions for further search. The gathering of numerical information wa. hased out in the first part of August when it appeared that the search was yielding few additional data. Work was redirected for the remaining allocated time to the collecting of geologic background information (stratigraphy, thicknesses, structure, etc.) in support of the hydrologic data. 
The main findings of the investigation are contained in tables at the end of the report. They are arranged geographically into 6 areas: 1-Pacific coast and Great Basin; 2-Rocky Mountains, Colorado Plateau, and Great PIains; 3-Mid-Continent; 4-Gulf Coast and Mississippi Embayment; 5-Appalachians and Great Lakes; and 6-East Coast and Triassic Basins. Each region contains a brief account of the geologic history, a stratigraphic table listing formation names, thicknesses, and lithology, and a table of hydrologic properties. The following findings are listed: Region 1-Vertical and horizontal conductivities of Recent to Pliocene shale; Region 2-Density, porosity, and conductivity of continental Eocene shale (Green River and Uinta formations) and marine Cretaceous shale (Pierre and related shales); Region 3: density and porosity of Pennsylvanian shale; Region 4: porosity and density of Cenozoic to Pennsylvanian shales; Region 5: density, porosity and electrical resistivity of paleozoic shales; and Region 6: density, porosity, conductivity, and difrusivity of Miocene to Triassic shale.

Additional geologic findings indicate that shales are predominantly composed of kaolinite, smectite, and illite (more commonly mixed illite/smectite layers) which change during burial. Clays which have not been buried below 
$1,400 \mathrm{~m}$ are rich in smectite, those which underwent burial to depths between $1,400 \mathrm{~m}$ and $3,800 \mathrm{~m}$ show progressive depletion in smectite (down to 20z), and those which reached depths in excess of 7,500 $\mathrm{m}$ are totally depleted in both smectite and illite. These changes are paralleled by a progressive disappearance in potassium feldspar, calcic plagioclase, and kaolinite. Age-related variations in smectite content have also been observed: Recent shale averages $70 \%$ smectite in mixed layers, Cenozoic and Mesozoic clay contains between $70 \%$ and $35 \%$ snectite, and pre-Mesozoic mixed layer clays contâin $35 \%$ or less smectite. By its variable ion-exchange and adsorption properties smectite has great influence upon the hydrologic properties of shale. Effects can be considerable, but more work is needed before they can be reliably predicted. In the present state of knowledge permeability of smectite-rich shale is likely to have the most unpredictable long-term behavior. Mathematical relationships have been proposed to relate permeability and porosity of shale. However, most fail to make accurate predictions probably because shale permeability measured directly on cores and drill holes is marred by the fissuring of boring tools. So far, the most successful results have been obtained from data derived from sonic logs and variations in pore 
pressures. The method, however, has not been properly tested for porosities below $10 \%$ and permeabilities below $10^{-6}$ darcys. 
INTRODUCTION

The aim of this report is: 1-To provide a data compilation of the permeabilities (nr hydranlis conductivities), porosities, densities, and a few additionai physical parameters of shale; 2- to provide a general outlook of the relationships which exist between these parameters; and 3- to outline areas where more search is needed for a better prediction of long-term behavior of waste repositories in shale.

Shale and related rocks, siltstone, mudstone, and claystone belong to a group of broadly represented relatively impervious rocks which offer some potential for longterm storage of radioactive wastes. Hydrologically, they are characterized by the uneommon combination of high porosity and low permeability which is related in part to their very fine grain-size. Their low permeability results in a scarcity of hydrologic data: neither oil companies nor hydrologists have been particularly eager to take measurements in rock of low economic importance. In addition, estimates of shale permeabilities in the subsurface by producing fluids from wells are difficult because shale normally produces no fluid. However, in the last decade the interest in shale as a hydrocarbon source 
has stimulated research. The list of available data is steadily growing, and it is likely that the tables of numerical parameters which are presented in this report will need updating in a foreseeable future. 
GEOLOGIC PROPERTIES OF SHALE

\section{1- DEFINITIONS}

Shale is the genezic nams givan to the wiaespread group of sedimentary rocks which is characterized by a predominance of silt and clay-size fractions. Variations in textures and structures are used to define specific rock names. Shale "proper", mudstone, siltstone, and claystone are the most common types.

The following definitions are quoted directly from the Glossary of Geologic Terms (AGI, 1972). These are important. to know as names given in the literature do not always have the same meaning.

Shale

"A fine-grained, indurated, detrital sedimentary rock formed by the consolidation (as by compression or cementation) of clay, silt, or mud and characterized by finely stratified (laminae 0.1-0.4 mm thick) structure and/or fissility that is approximately parallel to the bedding (along which the rack breaks readily into thin layers) and that is commonly most conspiclous on weathered surfaces, and by a composition with an appreciable content of clay minerals and with a high content of detrital quartz; a thinly laminuted or fissile claystone, siltstone or mudstone." ... "The term 'shale' is regardec sometimes as a 
structural term with the significance of thin bedding or fissility and without implying a particular composition: it has been loosely applied to massive or blocky indurated silts and clays that are not laminated, to laminated silts and clays that are not indurated, to fine-grained and thinly laminated sandstones, and to slates."

\section{Mudstone}

"(a) An indurated mud having the texture and composition, but lacking the fine lamination or fissility, of shale; a mucky or massive, fine-grained sedimentary rock in which the proportions of clay and silt are epproximately the same; a non-fissile mud shale."..."(b) A general term that includes clay silt, claystone, siltstone, shale, and argillite, and that should be used only when the amounts of clay and silt are not known."

\section{Siltstone}

"An indurated or sonewhat indurated silt having the texture and composition, but lacking the fine lamination or fissility, of shale: a massive mudstone in which the silt predominates over clay: a non-fissile shale. Pettijohn regards siltstone as a rock whose composition is intermediate between those of sandstone and shale and of which at least two-thirds is material of silt size." 


\section{Claystone}

"An indurated clay having the texture and compositicn, but lacking the fine lamination or fissility, of shale: a massive mudstone in which the clay prodominates over siit; a ron-fissile clay shale."

\section{Other Types of "Shales"}

Just about any type of fine-grained sedimentary rock

exhibiting laminations has been called "shale" by some field geologists. One example is Monterey Shale, a Miocene formation of Coastal California. Locally this rock is a finely layered diatomite enti rely composed of siliceous remains of diatoms with minimal amounts of clay. Another example is oil Shale, a hydrocarbon-xich member of the Green River Formation (Middle Eocene) of Utah and Wyoming. This rock is unusually rich in calcium carbonate and should be referred to as marl or marlstone, a European term sometimes used for rock, containing clay and calcite with minor amounts of other constituents.

In summary, the term "shale" has been applied indiscriminately to very diverse rocks: massive or finely layered, irdurated or soft, rich or devoid of clay minerals, fissile or not, etc. This abusive labelling practice has led to the inclusion of sedimentary rocks of widely different origins in one single category. Unfortunately, by looking 
through a list of references it is not uiways possible to determine the actual meaning implied by an author. mhis explains some of the wide range of variation in the hydrologic property of shale; for example, the hydraulic conductivity which spans over ten orders of magnitude.

\section{2- MINERALOGI}

A close relationship exists between the hydrologic properties of shale and its mineral content. It would seem, at first glance, that a good characteristic of shale is its high clay content and that the hydrologic properties wculd be related to the predominance of one clay mineral over the others, Although true in general, this statement is only partially correct because geologists have used the term "clay" to designate both a family of layered silicate minerals and a very fine grain-size (Iess than 4 microns). It is true that most clay minerals are in the clay-size range, but other minerals, particularly quartz, are sometimes found in the clay fraction. The Monterey shale (Miocene) of California, already mentioned, is sometimes made up entirely of cluy-size siliceous fragments. Another classic example is glacial "clay", a rock flour generally composed of nearly unalterei clay-size rock fragments. With this confusion, further compounded by the problems of definitions discussed earlier, there can be little doubt 
that the wide spectrum of hydrologic properties observed in shale is partly due to semantios. In order to minimize any sources of error, "clay" will be restricted in this report to mean clay minerals and "elay-size" to mean a size fraction less than 4 microns,

\section{Clays}

It would be beyond the scope of this report to give a complete mineralogic description of the most important constituents of shale. Only the general types of clays will be outlined here, and characteristics which affect the hydrologic properties will be emphasized. The interested reader can find additional information in references such as Weaver (1959) and Weaver and Pollard (1975). The clay minerals which are found in shale belong to the following trpes:

Kaolinite has a simple two-layer structure with little affinity for ionic exchange and adsorption. This clay somewhat lacks plasticity.

Illite. This mineral has a three-layer structure characterized by scme replacement of $\mathrm{Si}^{4+}$ by $\mathrm{Al}^{3+}$ combined with an addition of $\mathrm{k}^{+}$on the untside of the structure. This clay, sometimes called hydromuscovite, has moderate ion exchange properties, moderate adsorption affinities, and a variable plasticity. 
Smectite is another three-layer slay characterized by replacement of $\mathrm{Si}^{4+}$ by $\mathrm{Al}^{3+}$. In this case, however, electronic unbalance is compensated by the addition of various ions ( $\mathrm{Mg}, \mathrm{Fe}, \mathrm{zn}$, etc.) in the vacant octahedral sites inside the structure. Clays of this type have extreme variations in plasticity and ion exchange capabilities (swelling clays can absorb enormous amounts of fluids) and their physical properties are greatly affected by the nature of ions adsorbed. Na ions make thein sticky and plastic when wet; Ca ions make them less sticky and less prone to adsorb water. Quite expectedly, ion exchange also affects the hydrologic properties of shale and explains why some smectite rich rocks can behave as semi-permeable membranes (Berry, 1959). Other names used for minerals of this type are montmorillonite (when used in a generic sense) and bentonite.

Crlorites have composite structures which can be regarded as derivatives of kaolinite structure or as two illite structures tied by $\mathrm{Mg}^{2+}$ instead of $\mathrm{K}^{+}$. Rich in iron and magnesium, they lack the swelling properties of smectite. Mixed layer clays are combinations of two types of clays in a large structure. In some instances the layers follow an orderly pattern, in others they are random. The mixed illite/smectite layer clay is an important constituent of 
shale. Its properties are greatly dependent upon the content in smectite layers, but as a whole, they are intermediate between those of the two end members.

Other types. Among the less important clay constituents of shale are sepiolite, attapulgite, and hallophane.

Many clay minerals are very sensitive to prevailing physical and chemical conditions. Their relative abundance changes during burial in response to new pressure-temperature conditions and perhaps also to the duration of the burial process.

\section{Non-Clay Constituents}

Feldspars are common clastic constituents of shale, particularly in the silt-size fractions. Calcic plagioclase, albite, and potassium feldspars are all present in shale, and like clays, their relative abundance changes during burial through progressive disappearance of zotassium feldspa, and calcic plagioclase (Hower et al., 1976).

Quartz and amorphous silica varieties are found in all size fractions. They are derived from sources which are terrestrial (weathering, volcanism), biologic (sponges, diatoms), or are formed durinc diagenesis. All are subjected to mobilization by solution and deposition and 
may radically change the hydrologic properties of a rock by filling pore space and/or making it brittle.

Carbonates are primarily found as calcite and aragonite of biugenic origin. Their tencency to mobilize is greater than that of silica and results in concentrations in the form of concentrations or pore space fillings. Typical shale contains less carbonates than silica.

Detrital mica is mainly altered muscovite and occurs in the form of flakes which can impart fissility to the rock. In sumary, the physical properties of shale depend mainly upon the abundance of clay rinerals and the relative proportions of clay types. When kaolinite and illite predominate, rock properties are likely to remain fairly constant and predictable. When smectites and smectiterich mixed layer clays are the most common, rock properties can be unpredictable and be subjected to changes by reaction with pore fluids. Other minerals that are prescnt are less likely to have a widespread effect on shale properties.

3- ENVIRONMENTS OF DEPOSITION OF SHALE

Shale anu related rocks are found in sedimentary units of boti continentul and marine origin. The accumulation of fine-grained sediment requires (a) an abundant source of 
clay-size fragments generally derived from the chemical weathering of landmasses and (b) relative reduction in the proportion of coarser fractions either by sorting in a turbulent current (streams, surf, winc, etc.) or by sudden accumulation of clay-size fragments with no increase in the amount of deposited coarser fractions. Since such conditions can be realized in a multitude of ways, beds and lenses of shales can be expected in terrestrial. environments (flood plains, lakes), n.ar shorelines (lagoons, sheltered inlets), on the continental shelf (the "normal" setting of shale), or in abyssal plains (turbidites, clays, oozes). Shale is seldom found without other clastic sediments. When it predominates, stratigraphic units may be named after it: for example, chinle Shale is the aame of a Triassic formation of the Colorado Plateau which also contains sandstone and conglomerates.

Large accumulations of shale are mainly marine in origin. They are particularly thick in areas of high subsirience rates and moderate tectonic defo $\cdots$ on such as miogeoclines and stable continenta! maIgins itrailing edges). Surprisingly, iarge accumulations of shäle can also be found in terrestrial environments. One classic example is the Green River :urmation (Middle Eocene) which contains, in addition to trie sheie, siltstones and carbonate rich oil Shale. 
4- DIAGENESIS OF SHALE

Shale undergoes profound changes between the time it settles as a soft sediment and until it acquires the appearance of a rock. This "curing" process or diagenesis is quite complex: water is expelled by compaction, new minerals form, grain-size changes, the composition of pore Eluids is modified, and occasionally, pores are filled with silica or calcite. The following discussion deals mainly with the diagenetis effects which may affect the hydrologic properties of shale.

\section{Compaction}

Because deposition of shaly material takes place slowly and in a quiescent environment, the settled sediment is initially very rich in fluid--up to $90 \%$ (Smith, 1971). The platy habit of the clay results in a finely layered structure. This initial state reduces vertical permeabilities and influences the diagenetic changes which follow. As pressure of overlying sedinents increases, fluils are generally expelled, pores collapse, and the rock becomes dense and less permeable. The decrease in permeability may temporarily prevent fluids from escaping; thus the pore pressure rises while porosity and density remain nearly constant. This somewhat "anomalous" behavior is often observed in thick shale layers which have undergone rapid 
burial. Ultimately, the sequence of events ends with the expulsion of fluids and the formation of a compacted sedimentary rock.

\section{Mineralogic Changes}

Under the conditions of pressure and temperature which are likely to prevail in a depositional basin (less than $10 \mathrm{~km}$ deep, less thar $200^{\circ} \mathrm{C}$ ) the mineralogic changes affect mainly smectites and illite/smectite mixed layer clays. According to Powers (1967) smectite undergoes dehydration and begins to change to illite at a depth of $2,000 \mathrm{~m}$, and the reaction is complete at about $3,500 \mathrm{~m}$. More recently, this transitional process was thoroughly investigated by Hower et al. (1976), Aronson and Hower (1976), and Yeh and Savin (1977). Results show that between $1,400 \mathrm{~m}$ and $3,800 \mathrm{~m}$ and at temperatures between 44 and $100^{\circ} \mathrm{C}$ siales from the Gulf coast area exhibit a progressive enrichment of illite (from 20 to $80 \%$ ) in the illite/smectite mixed layer clays. No further change occurs until about $7,500 \mathrm{~m}$ (and at about $200^{\circ} \mathrm{g}$ ) where both, the remaining smectite and the illite disappear, and shales evolve into a low-grade greenschist assemblage of dioctahedral mica (muscovite), chlorite, albite, and quartz. The initial change follows the scheme:

$$
\text { smectite }+\mathrm{K}^{+}+\mathrm{Al}^{3+}-\ldots \text { illite }+\mathrm{Si}^{4+}+\mathrm{H}_{2} \mathrm{O}
$$


and is not reversible. The potassium and aluminium are supplied by potassium feldspar, calcic plagioclase, and kaolinite, which show a conspicuous disappearance at depth. The reaction is further complicated by a loss of iron and magnesium.

Diagenetic changes have a tremendous impact on the hydrologic properties $0:$ shale. Changes in the smectite composition lower the variability in the plasticity, ion exchange characteristics, hyoration-dehydration, semipermeable behavior, etc. Water release, increased compaction, silica release and silicification may be equally important in some cases (Towe, 1962). The extreme conditions which are needed to eliminate completely the mixed layer clays are not common occurrences except perhaps in deeply buried, hence often oldest, shale, such as the argillites of the Precambrian Belt Series of Montana and Idaho (Maxwell and Hower, 1967).

There is compelling evidence that a relationship, perhaps unrelated to burial, exists between clay mineralog: and the age of the shale. Kaolinite and smectite-rich mixed layer clays are more common in Cenozoic shale whereas shlorite and illite predominate in pre-Mesozoic clays. This change may reflect (1) a variation in the source material, (2) deeper burial or (3) a dependence on the rate 
of reaction for diagenetic changes. The two latter possibilities cannot be easily distinguished, but Hower et al. (1976) have concluded that burial metamorphism is at least partly responsible. They found that recent clays (which underwent shallow burial) contain 30 illite, that Cenozoic and Mesozoic clays (buried to variable depths) contain between 30 and $65 \%$ of randomly stratified illite, and that pre-Mesozoic clays contain 658 illite with ordered interstratification. Sinilar age-related changes are found with other minerals. Among them are the progressive disappearance of carbonates, calcic plagioclase, and potassium feldspars and the progressive increase in quartz and albite.

Although these diagenetic reactions are able to alter drastically the hydrologic properties of shale, such modifications are unlikely to be felt within the expected life span of a waste repository. A more important practical aspect of shale diagenesis is that, for repository purposes, rocks with less smectite in the clay fraction will be less reactive with ground water. For that reason older rocks are likely to have more predictable hydrologic properties.

\section{Changes in Pore Fluids}

The composition of pore fluids in the early stages of burial is the same as that of the environment of deposition: 
fresh water or lake brine for terrestrial sediments and sea water for marine deposits. Later, interactions with the surrounding rocks occur: the transformation of smectite into illite decreases tine $\mathrm{K} / \mathrm{Na}$ ratio, and $\mathrm{E}_{\mathrm{h}}$ and $\mathrm{pH}$ undergo changes which affect the concentrations of $\mathrm{SO}_{3}{ }^{2-}$, $\mathrm{H}_{2} \mathrm{~S}, \mathrm{NH}_{4}^{+}$, and $\mathrm{NO}_{3}{ }^{-}$. As the ion exchange sitas on the clays become saturated, the shale acts as a semi-permeable membrane. The resultant osmotic pressures have been observed to modify predicted patterns of fluid flow by their effect on hydraulic gradients (Berry, 1959).

\section{Other Changes}

A cominon diagenetic change is the growth of larger grains at the expense of smaller fragments of the same materials. In shale the process affects more often quartz and carbonates than clays and contributes to the filling of pores and the disappearance of plasticity. Locally, it may result in a dense massive rock in which later deformations may induce fracture permeabilities much higher than those ordinarily found in shale.

To sum up, during diagenesis the physical, chemical, and hydrologic properties of shale can be modified by predictable regional factors--depth of burial, age, initial composition, etc.--or by local conditions which are more dificult to evaluate--osmosis, loss of plasticity, etc. 
5- POST DIÄGENE'ILC CHANGES

Two changes which affect the hydrologic properties of shale after diagenesis are late fracturing and modification of the pore space in response to the circulation of ground fluids. The first effect is likely to be sigrificant in areas of active faulting, particularly over a time span of 100,000 years. The second may be important in areas of active volcanism where hot fluids are potent agents of solution and deposition.

6- MAJOR SHALE OCCURRENCES

IN THE UNITED STATES

Shale appears on nearly all geologic maps of the United States. Many units are in the form of thin interbeds in clastic sequences and, as such, offer limited potential for repository sites. Others, more suitable for such use, occur in massive beds up to a thousand meters thick and have a wide areal extent.

The thickest and widest shale units are Cenozoic and Mesozoic in age and are found mainly west of the Mississippi Valley. Believed to be the source of many petroleun deposits, they have received more attention than the older shale. A few widespread Paleozoic shales are found, mainly east of the Rocky Mountains, and occasionally, 
thick Precambrian shales have been described in scattered parts of the continent. The following major shale units are listed in order of increasing age:

\section{Tertiary Shale}

Shale of marine origin is found in the thick clastic wedges of California (Great Valley, Coast and Transverse ranges) and the Gulf Coast. Its age ranges from Pliocene to Miocene in the Coast Range and to Eocene elsewhere. Shale of continental origin reaches considerable thickness in the northern Colorado Plateau (Green River Basin of Eocene age).

\section{Cretaceous Shale}

Shale of Cretaceous age occurs in several areas. Its greatest extent is a vast blanket spread from the Colorado Plateau to the edge of the Appalachians and from the Canadian Rockies to the Gulf Coast. This broad unit has received varicus names: it is best known as the Pierre Shale in the northern Great plains and has been correlated elsewhere with such units as the Adaville, Mentor, Benton, etc. Also, the thick Mancos Shale from the Mesa Verde Wedge is partially time-equivalent to the Pierre Shale. Cretaceous shale is also found along the Atlantic coast (Middendorf Shale) and in the Great Valley sequence of California. 


\section{Jurassic and Triassic Shale}

In contrast with previous groups, Jurassic and Triassic shale is rather uncommon. Exception is the continertal shale in the Colorado Plateau Upper Jurassic Morrison Formation) and along the East Coast (Brunswick Shale in Triassic Basins).

\section{Paleozoic and Precambrian \\ Shale}

A particularly persistent shale unit occupies the Upper Paleozoic section between the Rocky Mountains and the East Coast. It is best known as the Chattanooga Shale with other names being approximate equivalents: Cherokee, stanley, Hamilton, etc., but it must be pointed out that this unit does not have the same age everywhere (Clark. and Stearns, 1968). Beyond the limits of the Chattanooga Shale, a somewhat similar unit is found in the Great Basin (eastern Nevada and western Utah). It is the Eleana Formation (Devonian-Mississippian) which is part of a thick flysch sequence in the Antler Trounh (Foole and Sandberg, 1977). Finally, a few instances of large shale units have been reported in the Upper Precambrian, for example, the Terrigenous Detrital sequence which occupies the same general arsa as the Elena Formation in the Great Basin and the Nonesuch Formation in the Northern Appalachians. Within the context of the data obtained 
during the bibliographic search the shale-rich formations which are most favorable for use as waste repositories are those of Cenozoic age along the West and Gulf coast regions, those of Mesozoic age in the central portion of the country, and those of Triassic and Paleozoic age in the eastern half of the United States. These units are covered in the hydrologic part of this report. Formations which could be favorable but for which data were not available are listed in the Stratigraphic Tables. 


\section{THE HYDROLOGIC PROPERTIES OF SHALE}

The preceding section provides a qualitative description of the factors which control the hydrologic properties of shale. This section discusses the quantitative aspects of the hydrologic parameters and their mathe matical relationships. This review also will show areas of knowledge where further research is critically needed.

\section{1- BRIEF REVIE: OF IMPORTANT PARAMETERS}

This review will be limited to the rock properties which are discussed in this report or listed in the hydrologic tables.

\section{Porosity}

Percent porosity, $\phi$, is the ratio of void spact $v_{v}$, to the bulk volume of the rock $\left(v_{\text {solid }}+v_{v}\right)$. Where:

$$
\phi=\frac{v_{v} \times 100}{v_{\text {solid }}+v_{v}}
$$

In hydrology there is some advantage in distinguishing absolute porosity (total void porosity) from effective porosity (connected-void porosity). Only the latter is related to rock permeability, but in the case of shale the 
distinction becomes unclear by the fact that pore conne tion varies with the amount of adsorbed fluid which may swell the clay particles. When reservoir properties have to be estimated, it is also important to distinguish primary porosity which is widespread and more easy to predict from secondary porosity, fracture or solution, porosity which is controlled by local and more variable factors.

\section{Permeability}

Permeability is a measure of the ability of a fluid to flow through rocks under a pressure gradient. It is an intrinsic rock property which, in the CGS system, is expressed either in darcys or in $\mathrm{cm}^{2}$, with the equivalence:

$$
1 \text { darcy }=9.87 \times 10^{-9} \mathrm{~cm}^{2}
$$

A related parameter is hydraulic conductivity $\left(K^{\star}\right)$ which appears in Darcy's law as:

$$
K^{*}=Q H / A \text {, }
$$

where $Q$ is the fluid discharge, A the area through which the fluid moves, and $H$ is the hydraulic gradient (change of elevation or pressure). The hydraulic conductivity and permeability $k$ are related by the expression:

$$
\mathrm{K}^{*}=\frac{\mathrm{kg}}{\mathrm{v}}
$$


where $v$ is the kinematic viscosity (in stokes) and $g$ the gravity acceleration. In the metric systen hydraliic conductivity is expressed with the dimensions of velucity: $\mathrm{cm} / \mathrm{sec}, \mathrm{m} / \mathrm{yr}$ etc: The following are convenient expressions of $k^{*}$ :

$$
\begin{aligned}
& 1 \mathrm{~cm} / \mathrm{sec} \cong 1.03 \times 10^{3} \text { darcys (for water at } 20^{\circ} \mathrm{C} \text { ) } \\
& 1 \mathrm{~m} / \mathrm{yr} \cong 3.27 \times 10^{-3} \text { darcys } \\
& 1 \text { darcy } \cong 306 \mathrm{~m} / \mathrm{yr} .
\end{aligned}
$$

It must be noted that, due to the kinematic viscosity factor, the hydraulic conductivity varies with temperature. Thus, at $100^{\circ} \mathrm{C}$,

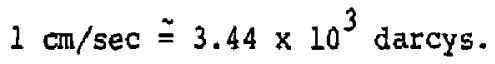

Permeability and hydraulic conductivity are directional properties which can vary substantially. The scant di ia available (see, for example, Table Region I, Core-Hole $65 / 2 \mathrm{~W}-24 \mathrm{C7}$, Santa Clara Valley) suggest that variations can reach two orders of magnitude. It is important to remember that most permeabilities are measured along the beding ("horizontally") and that in shale such values are the highest. In the exceptional case where "vertical" permeabilities are greater, there is evidence of fracturing or solution. When permeabilities are isotropic there is indication of a uniform equigranular medium which is more 
likely to be found in silstone than in shale or mudstone.

\section{Other Parameters}

Diffusivity. Hydraulic diffusivity $\alpha$ is defined by the expression:

$$
\alpha=\frac{K^{*} D}{S}
$$

where $K^{*}$ is the hydraulic conductivity. For an unconfined system, $D$ is the average saturation thickness and $S$ represents the specific yield. For a confined system, $D$ is the thickness of the producing formation and $S$ is the storage coefficient. Diffusivity enters in the calculation of movements of transient volumes or "slugs" of fluj.d.

Rock density is a property which is obtained routinely from well logs. It can be used as a rough indicator of porosity provided that the grain density can be assuied to be constant (generally around 2.65). In that case, the porosity $\phi$ should be:

$$
\phi=\frac{2.65-d}{2.65} \times 100
$$

where $d$ is the dry density of the sample. This figure, however, does not take into account the fact that water 
adsorbtion can sweld clays from the solis rraction and reduce the grain density. In p:actice measured porosities of shale can be nearly 50 o less than those predicted by the equation.

Well logging parameters. Among the data which are obtained from well $\operatorname{logs}$ are the electrical resistivity and self potential from which porosities and permeabilities can be estimated in situ. Another useful pardmeter is the acous'ic transit time obtained from sonic logs. Magara (1973) has derived the following empirical relationship between acoustic transit time $\Delta t$ and porosity $\phi$ :

$$
\phi=0.00472 \Delta t_{\text {shale }}-0.362
$$

The tansit time is measured in microsec/ft. The equation holds true for Cretaceous and Tertiary shale of North America.

\section{2- MATHEMATICAL RELATIONSHIPS}

Permeability measurements are difficult to obtain in a laboratory because core drilling often induces cracks or fissures. Typically the values obtained are too high and erratic. In situ estimates of shale permeability by producing fluid from a drill hole are also difficult because shale normally produces no fluid. For this reason. 
nany attempts have been made to determine permeability from well log data. Some of the most useful expressions are described below.

Permeability-porosity relationships appeared in the literature long ago. The most familiar was derived by Kozeny in 1927 (in Magara, 1973) and has the form:

$$
k=\frac{P}{B A_{g}} \times \frac{\phi^{3}}{(1-\phi)^{2}}
$$

where $A_{g}$ is the grain area per unit volume, $P$ and $B$ are parameters related, respectively, to the pore shape and to the "tortuosity" of the pore, and $k$ and $\phi$ are, respectively, permeability and porosity. In practice these empirical parameters are incorporated in simplified equations. Ryder (in Levorsen, 1967) suggested:

$$
k=\frac{2 \times 10^{7}}{\mathrm{~A}_{g}^{2}} \times \frac{\phi^{3}}{(1-\phi)^{3}}
$$

Vasquez (in Smith, 1971) proposed:

$$
k=b \frac{\phi^{a}}{(1-\phi)^{c}}
$$

where $a, b$, and $c$ are deriveâ empirically for particular rock types. He used $a=8$ and $c=0$ for shale, figures also used by Smith $(1971,1973)$, and Archie (in Magara, 
1973) used a value of 5.5 for a and 0 for $c$, A different and, perhaps, more reliable procedure was used by Magara (1973) who, using porosities from acoustic logs in incompletely compacted shales and fluid pressure gradients, was able to predict quite accurately the permeabilities of Cretaceous shales of central Canada (equivalents of the Pierre Shale).

The various predictions are shown in Figure 1 where the extent of their reliability can be easily tested. It is readily seen that Magara's data derived from well logs plot more accurately than laboratory derived determinations. However, the lack of data below porosities of $10 \%$ makes extrapolations questiorable in that direction. A word of caution is needed to remind that the described relationships do not include fracture permeability. Studies by Weoster et al. (1970) on metamorphic rocks seem to suggest that substantial conductivity $\left(5 \times 10^{-7} \mathrm{~cm} / \mathrm{s}\right)$ can be associated with exceedingly small porosities $(0.01 \%)$. Similar figures may apply perhaps to the non-porous Paleozoic shale listed in the tables below.

Porosity-depth relationships are a necessary supplement to the calculations above. The simplest models take the exponential form suggested by Rubey and Hubbard (1959): 


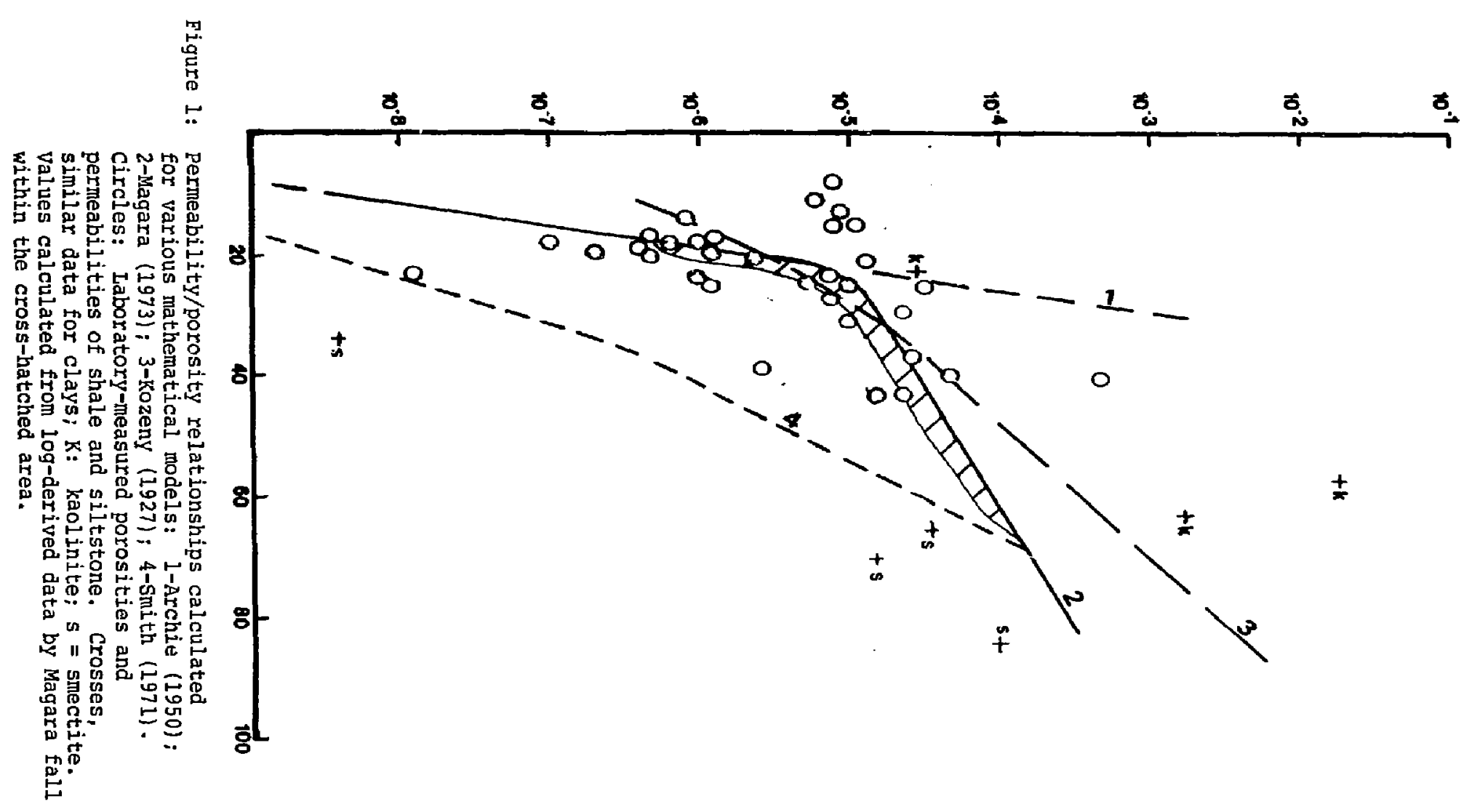




$$
\phi=\phi_{0} \mathrm{e}^{-\mathrm{cz}}
$$

where $z$ is depth, $\phi_{0}$ a reference, surface porosity, and c an empirical constant. For Cretaceous and Tertiary shale of North America and Japan Magara (1973) derived the expression:

$$
\phi=0.6 \mathrm{e}^{-0.0000193} \mathrm{z}(\mathrm{cm}) .
$$

Athy (in Smith, 1971) used the following equation for shale of north-central Oklahoma and Kansas:

$$
\phi=0.48 e^{-0.0014} z(m)
$$

Such equations give values of so-called "normal porosity" characteristic of rocks where hydrostatic pore pressures prevail. It is against these references that pore overpressures due to rapid burial can be evaluated.

The previous discussions have been concerned mainly with primary porosity and bear little relationship to Eracturing. Although Snow (1968) found that frasture porosity of most rocks decreases exponentially with depth (an order of magnitude every $61 \mathrm{~m})$, du Rouchet (1978) has shown that open fractures can develop spontaneously in shale subjected to high pore pressures at depths between 1,000 and 2,000 it. 
Theoretical models give permeability relacionships which are seemingly more reliable than those derived from laboratory measurements only whon porosities exceed $10 \%$ and permeabilities higher than $10^{-8}$ darcys $(3.06 \mathrm{~m} / \mathrm{yr})$. Below these levels the calculated permeability figures could be in error by several orders of magnitude.

\section{3- LITHOLOGIC PARAMETERS}

Kozeny's equation contains an explicit statement of most lithologic factors likely to affect shale permeability (witin the exception of grain mineralogy); the specifin surface is related to grain size, the pore shape is related to the sphericity and roundness of grains, and the tortuosity is related to sorting (although such a statement is an obvious oversimplification). In the case of shale the relationship between porosity and permeability is complicated further by the fact that clay minerals have widely different surface pioperties. A look at Figure 1 shows that laboratory-measured permeabilities of kaolinite are generally higher than corresponding values for smectite. According to Mielenz and king (1955) both clays are found in the same size fraction, and rince both have a similar piaty habit, it is likely that the differences must be accounted for by the high adsorption characteristics of smectites. Harman and Fraulini (1940) have shown that the 
permeability of kaolinite desreases by a factor of 3.5 when its specific surface is increased from $30 \mathrm{~m}^{2}$ to $240 \mathrm{~m}^{2}$. In the absence of other data one might speculate that similar changes could exist for other clay rinerals as well.

4- DIAGENETIC AND POST DIAGENETIC

CHANGES

\section{Compaction}

The effect of compaction on the hydrologic properties of shale has been well investigated (Smith, 1971, 1973; Magara, 1973). Because of the low permeabilities of clays, rapid burial of clay-rich sediments may result in a build-up of fluid pressure and lead to abnormal porosity/depth relationships. Using similar approaches, Smith and Magara showed that these "abnormally" high pore pressures can persist for tens of millions of years, a fact also observed by Magara in the Upper C-etaceous shale of Canada. Smith (1971) has presented tables listing calculated variations in porosity, permeability, pressure, water velocity, etc. These calculated figures suggest that during compaction, permeability increases in general (and up to tenfold) while porosity decreases. It should be reminded, however, that Smith's assumptions about initial porosity/permeability relationships disagree with the seemingly more accurate 
estimates of Magara (1973). There seems to be a consensus that compaction overpressures are unlikely to extend into the Paleozoic strata.

\section{Mineralogic Changes}

General knowledge of the adsorbing properties of clays suggests that the illitization of smectites is likely to be accompanied with important changes in hydrologic properties shale. For the present, however, numerica: data is scant. In a series of experiments, Magara (1973) has shown that pore overpressure was not related to mineralogic changes at least to depths of $700 \mathrm{~m}$. Both Powers (1967) and Hower et al. (1976) agree that the change of smectite to illite is accompanied with dehydration, but such changes should not operate at depths of less than $1250 \mathrm{~m}$ lobserved by Hower et al., 1976, in Gulf coast shale).

\section{Reactions with Pore Fluids}

Permeability of shale is likely to be affected during reaction with pore fluids, but precise data is once again scant. Samuels (1950) has shown that charges and nature of dissolved ions affect permeabilities (the higher the charge, the greater the permeability). Smectites are more affected than kaolinite (Fig. 2) with permeability ratios (Al/Na) being, respectively, 0 and 3.5 . It is important to note that, although permeabilities decrease with pressure, 

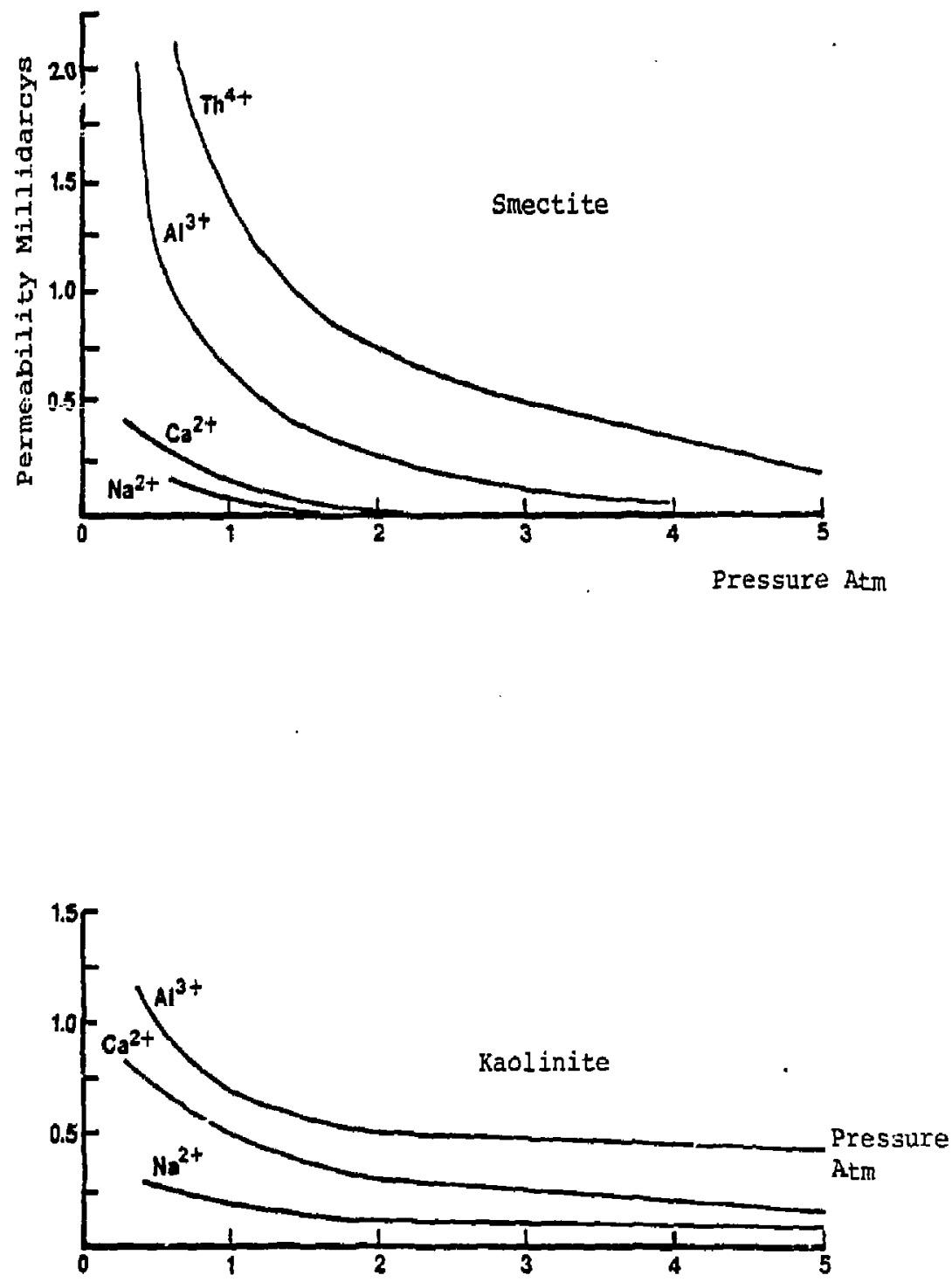

Figure 2: Effect of ion adsorption upon the permeability of two clay minerals: smectite (montmorillonite) and kaolinite. (From Samuels, 1950). In all cases clays are saturated with the particular cations. 
their ratios remain seemingly constant. Presumabjv; illite would have a behavior somewhere between $\_$ite and illite, and a reasonable guess would be that the ionic substitution effect would be reduced during the illitization of smectite-rich sediments. Another guess would be that permeability of shale can increase if different ions are introduced by ground water movements.

\section{Cementation}

Since the illitization of clay is a possible source of soluble silica (Towe, 1962), drastic drops in porosity and permeability can be expected during burial. If such changes were to take place, however, they would produce anomaious porosity/permeability relationships which may be detectable on curves such as those of Figure 1. Obviously, a silicified shale could also yield rocks of high fracture permability, but such instan.es would be very difficult to predict.

\section{CONCLUUSIONS}

The preceding discussions are perhaps more revealing of the great gaps in our knowledge of relationships between lithology and hydrologic properties. It is true that much work remains to be done before accurate predictions for long periods of time become possible, but a few important facts have been established: 1--within a formation of 
particular age reliable correlations between permeability and porosity can be established (this method has been used for estimating some of the figures shown in the tables below): 2--Mineral composition must be known in orcer to predict possible long-term effects of ion exchange on shale; an 1 3--The chemical composition of pore fluids must be determined in order to predict possible effect of fluid waste leakage on enclosing rocks. On the other hand, more work is needed to be able to predict permeabilities below $10^{-8}$ darcys, and to determine the effect of burial on the hydrologic properties of clays. The tables which follow show that the hydrologic data for shale is rapidly growing and provide a bright outlook for future research. 


\section{THE FYDROLOGIC CHARACTERISTICS OF SHALE}

IN THE UNITED STATES

ORGANIZATION OF THE DATA

The following lists of hydrologic properties of shales are divided anong six geologic areas (Fig. 3). Each list is preceded by a brief description of the geology of the region and a stratigraphic table designed to show the position of the shales with respect to other geologic units.

For each region permeabilities, porosities, and densities are presented first, and the other parameters for which there are less data are listed in a separate "additional data" sheet. Bibliographic references of the hydrologic data are listed in alphabetical order with each section to make them more readily available for further search.

In general, permeability values were changed into water conductivities at $15^{\circ} \mathrm{C}$ using the equivalence:*

$$
1 \text { darcy }=8.54 \times 10^{-4} \mathrm{~cm} / \mathrm{s} \text {. }
$$

*S. Davis and R. DeWiest, 1966, Hydrogeology, p. 165, John Wiley \& Sons, New York. 


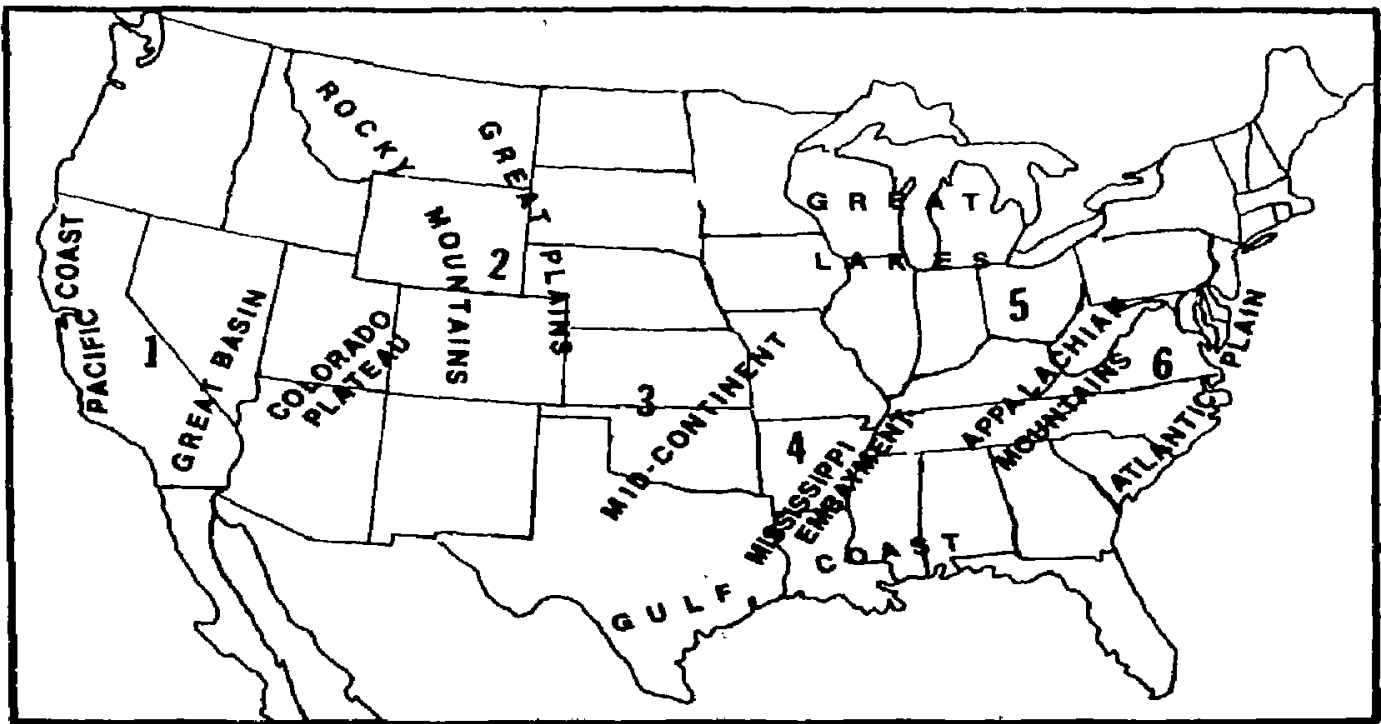

Figure 3. Location of areas containing shales which are discussed in the table of hydrologic properties. 


\section{REGION 1: PACIFIC COAST- \\ C AA" VALIEY-GREAT BASIN}

The western edge of the American continent has been at the forefront of converging plate activity at ieast since Mid-Paleozoic times and lasted intermittently until Late Cenozoic when subduction was replaced by a combination of transcurrent regime along the San Andreas Fault System - .d of tensional deformation in the Great Basin (Atwater, 1970). As plates were consumed under North America, shale-rich sediments were laid down in a series of linear lasins more or less parallel to the present Pacific sinorelines. The oldest zone of deposition developed during the paleozoic in an area presently located in eastern Nevada and western Utah; the younger ones appeared in the Great Valley of California and in the Coastal and Transverse Ranges. The following shales are associated with these zones.

-The Great Basin sh=ies belong to the Terrigenous Detrital Sequence (Stewart and Suczek, 1977), and the Eleana formation respectively, of EocambrianCambrian and Devonian Mississippian ages. Stewart and Suczek (1977) believe that their Terrigeneous Detrital sequence evolved during the early stages of opening of ancestral Pacific ocean. Its location is shown in Figure 4. 


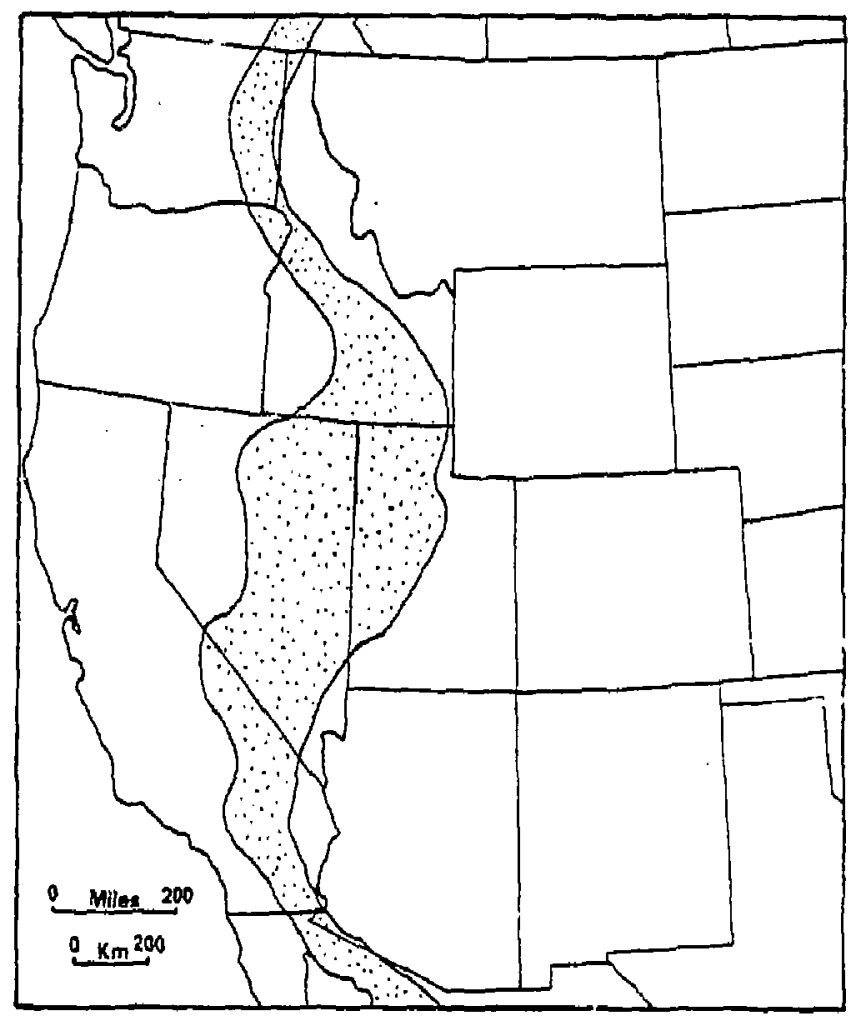

Figure 4: Map showing the location of the Cambrian Terrigenous Sequence in the Great Basin. (From Stewart and Suczek; 1977). The stippled area scows the zone where the thickness of the sequence exceeds $300 \mathrm{~m}$. 
The Eleana Formation represents, according to Poole and Sandberg (1977), a forearc assemblage of the Antler geosyncline. Figure 5 shows its general lovation and thickness. Both shales of the Great Basin are included into the stratigraphic Table 4-1-a.

The great Valley shales developed within a Mesozoic, and perhaps Tertiary, forearc basin which persisted nearly unchanged until present. During that time alternations of shale and sandstone were accumulated to thicknesses which exceed locally 10,000 meters mainly as Cretaceous, flysch-type, Great Valley sequence. The Panoche Formation is an example of a predominately shaly unit which locally reaches thicknesses of $6,700 \mathrm{~m}$. The bibliographic search which was undertaken as part of this report did not include parameter values for this formation. Further search would be useful.

Cenozoic shale of the Great Valley is much thinner (less than 1,000 m) but, being associated with oil and gas fields, the rock has undergone more scrutiny. The many names of the shale formations of that group (Eocene to Pliocene) are shown in Table $4-1-b$.

Coastal shale is Miocene and Pliocene in age and represents western extensions of similar units in the Great valley. 


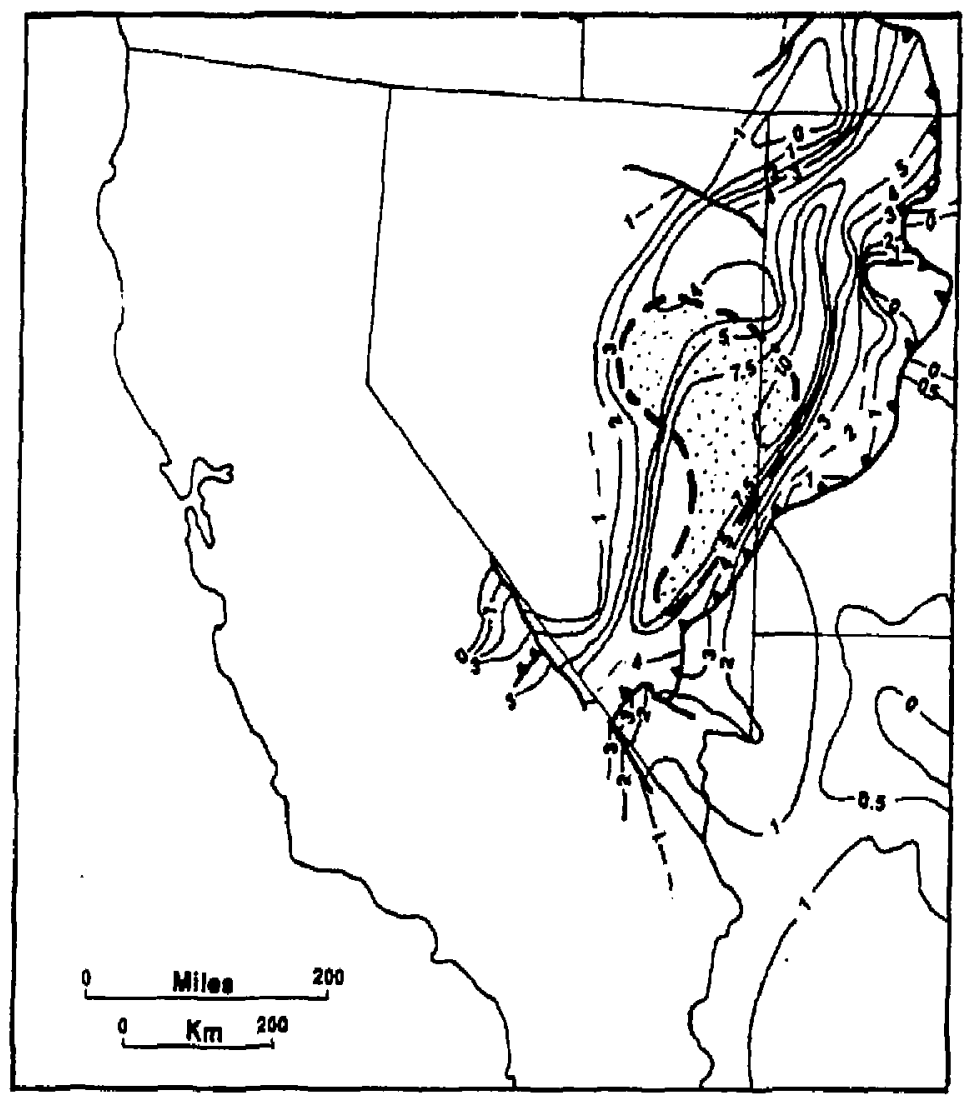

Figure 5: Map showing the location of the Eleana Formation Facies (dotted area) within the Upper DevonianMississippian of the Great Basin (after Poole and Sandberg, 1977). Isopacs are labelled in 100 meters. 
It is associated with hydrocarbon deposits. Examples of the structural style characterizing Great valley and Coastal Range are given in Figures 6 and 7. Detailed stratigraphy is shown in Table 4-1-3. 


\section{IEMBLOR RANGE}

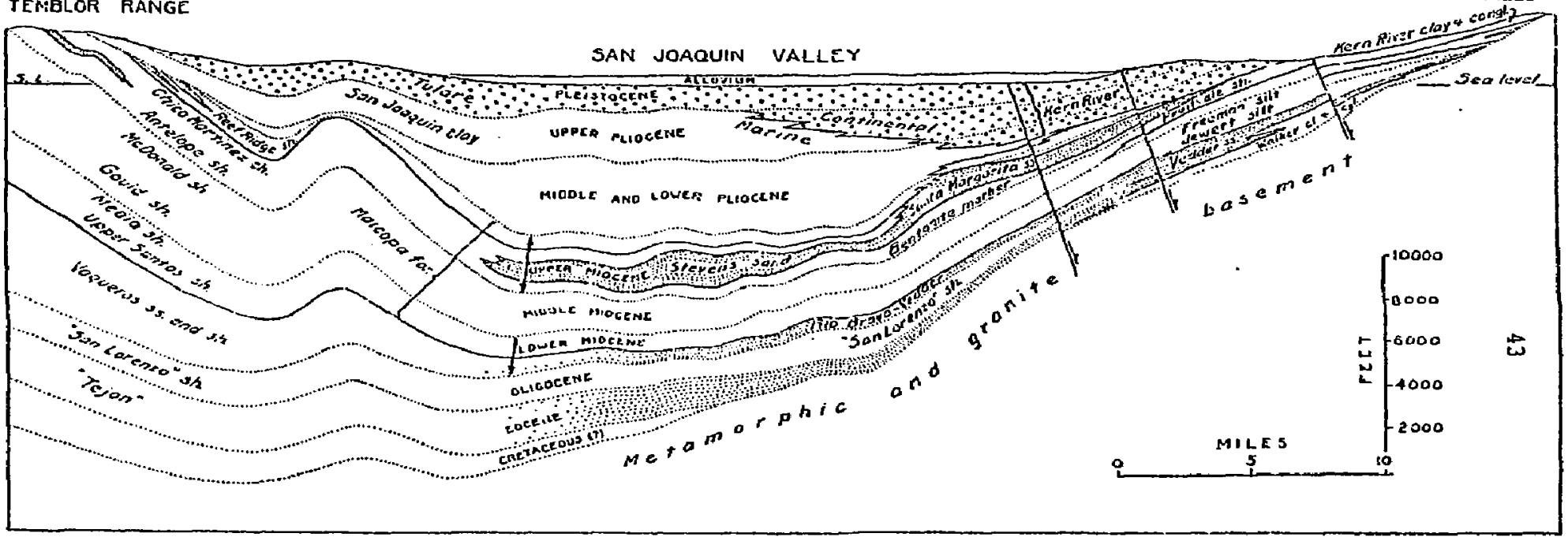

Figure 6: Generalized section across the San Joaguin Valley. (From Eardley, 


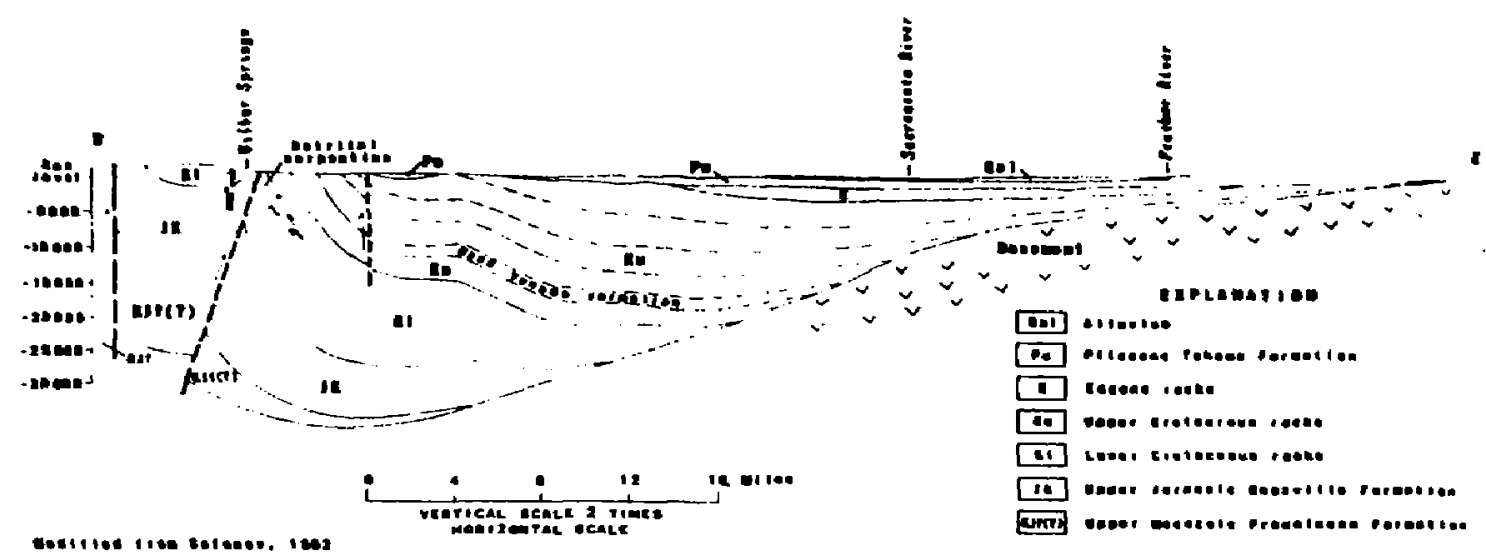

Figure 7: Generalized section across the Sacramento Valley. Designed to show the thickness of Mesozoic sediments after

D.o. Emerson and E.I. Rich, I966, In Bul1. 190, Calif. Div. of Mines and Geol., San Francisco, p. 476. 
SUMMARY OF PAIEOZOIC ROCKS IN THE GREAT FASIN (EASTEFN NEVADA, WESTERN UTAH) [From Stewart and Suczek, 1977]

NOTE: Shales described in the hydrologic tables are preceded by *.

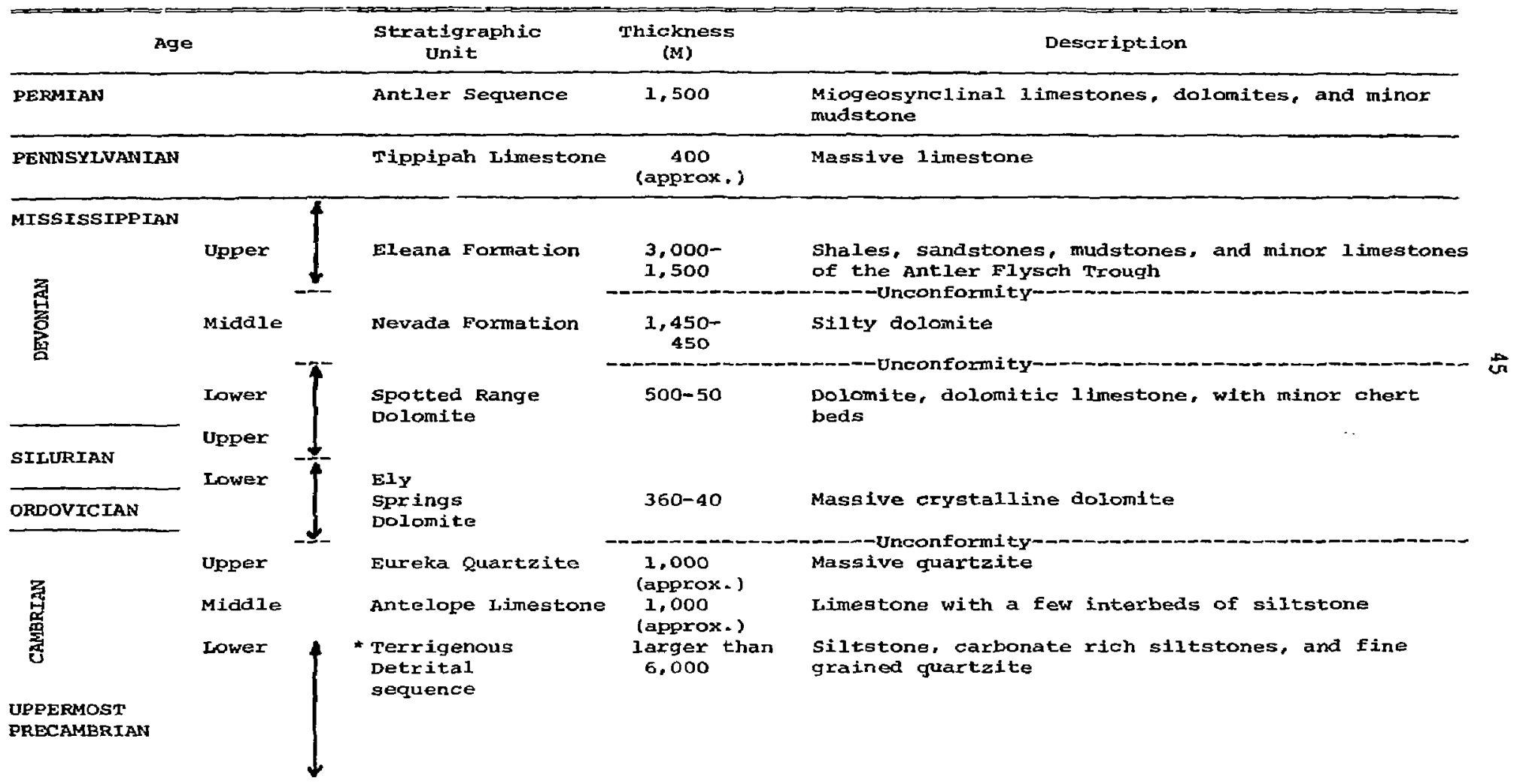


TAgLE 4-1-b SUMMARY OF ROCK UNITS IN THE SAN JOAQUIN VALLEY AREA, CALIFORNIA [From Kirby (1943), Hackel (1966), and Maher et al, (1966)]

NOTE: Shales described in the hydrologic tables are preceded by *

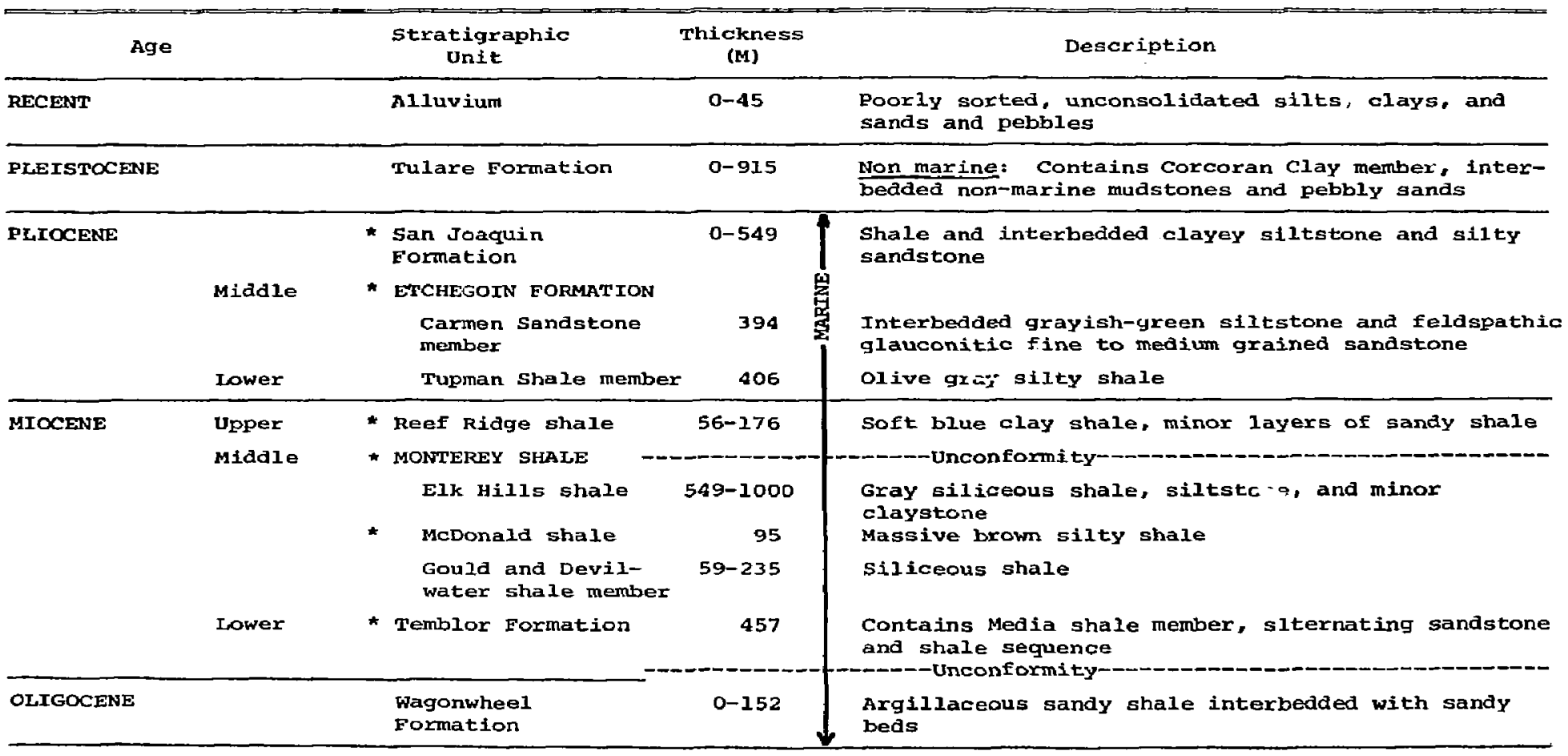


Table 4-1-b (continued)

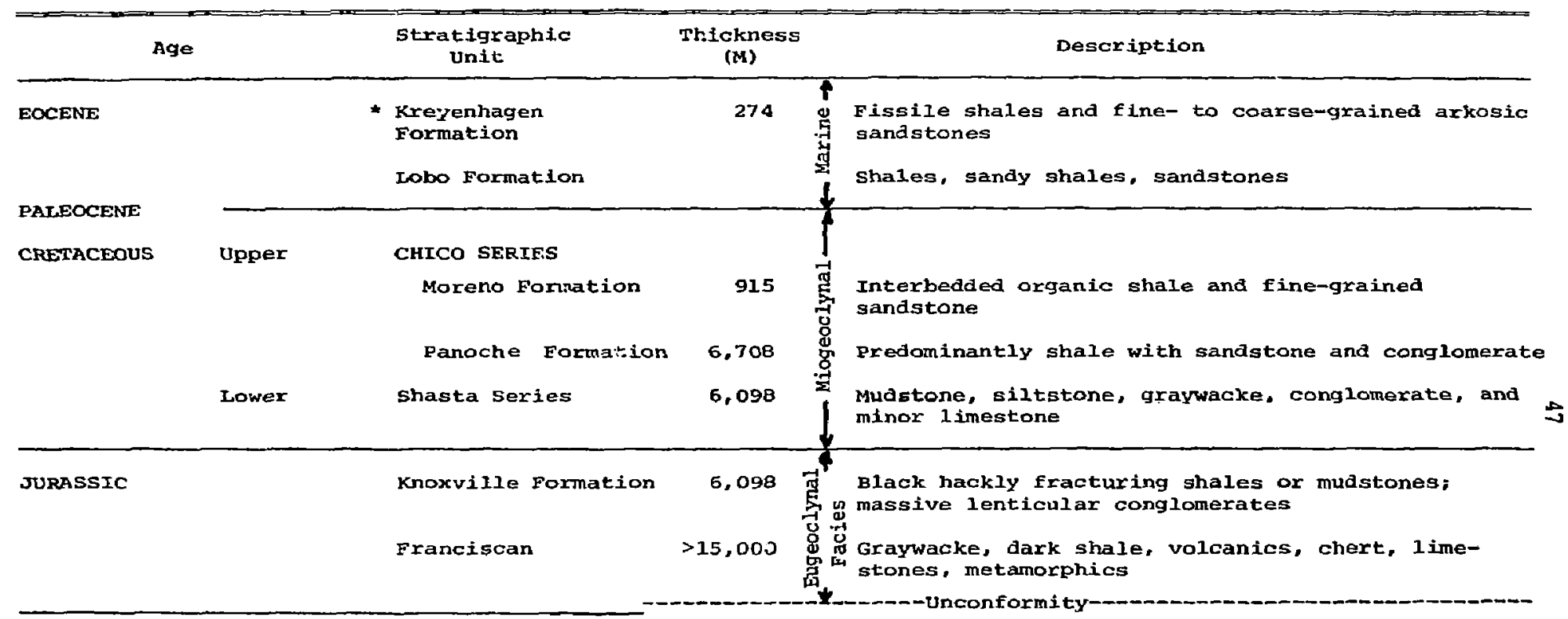

PRE-JURASSIC

a paleozoic 
TABIE 4-1-C SUMMARY OF ROCK UNITS IN THE CALIFORNIA COAST RANGES

[From Page (1966), Cummings et al. (1962) and Kirby (1943)]

Nore: Shales described in the hydrologic tables are preceded by *

\begin{tabular}{|c|c|c|c|}
\hline Age & $\begin{array}{l}\text { Stratigraphic } \\
\text { Unit }\end{array}$ & $\begin{array}{l}\text { Thickness } \\
\text { (M) }\end{array}$ & Description \\
\hline PLEISTOCENE & Terrace Deposits & 12 & Interbedded coarse sand and gravels. \\
\hline $\begin{array}{l}\text { PLIO- } \\
\text { PIEISTOCENE }\end{array}$ & $\begin{array}{l}\text { *anta clara } \\
\text { Formation }\end{array}$ & 549 & $\begin{array}{l}\text { Poorly consolidated, interbedded conglomerates. } \\
\text { sandstone end mudstone }\end{array}$ \\
\hline $\begin{array}{l}\text { PLIOCENE AND } \\
\text { MIO-PLIOCENE }\end{array}$ & Purisima Formation & 1,723 & $\begin{array}{l}\text { Sandstone, mudstone, siliceous mudstone and } \\
\text { porcellanite, volcanic sandstomes, diatomite, } \\
\text { vitritio tuffs }\end{array}$ \\
\hline \multirow[t]{2}{*}{ MIOCENE: } & * Monterey Formation & 2,744 & $\begin{array}{l}\text { Light-colored, diatomaceous and siliceous shale } \\
\text { and sandstones }\end{array}$ \\
\hline & Minaego Formation & $610-1,220$ & $\begin{array}{l}\text { Complex interstratified basaltic volcanic rocks, } \\
\text { mudstone, sandstone, and carbonates }\end{array}$ \\
\hline \multirow[t]{2}{*}{ OLIGOCENE } & Vaqueros Sandstone & $732-1,372$ & $\begin{array}{l}\text { Fine-to-medium-grained arkosic arenite with } \\
\text { interbedded shale and mudstone }\end{array}$ \\
\hline & $\begin{array}{l}\text { San Lorenzo } \\
\text { Foxmation }\end{array}$ & $396-823$ & Mudstone and shale \\
\hline EOCENE & Butano Sandistone & & $\begin{array}{l}\text { Arkasic sandstone, including turbidite, with } \\
\text { muditone interbeds }\end{array}$ \\
\hline PALEOCENE & Logatelli Formation & $76-244$ & Dark gray, massive siltstone \\
\hline
\end{tabular}


TABLE $4-1-C$ (Cortinued)

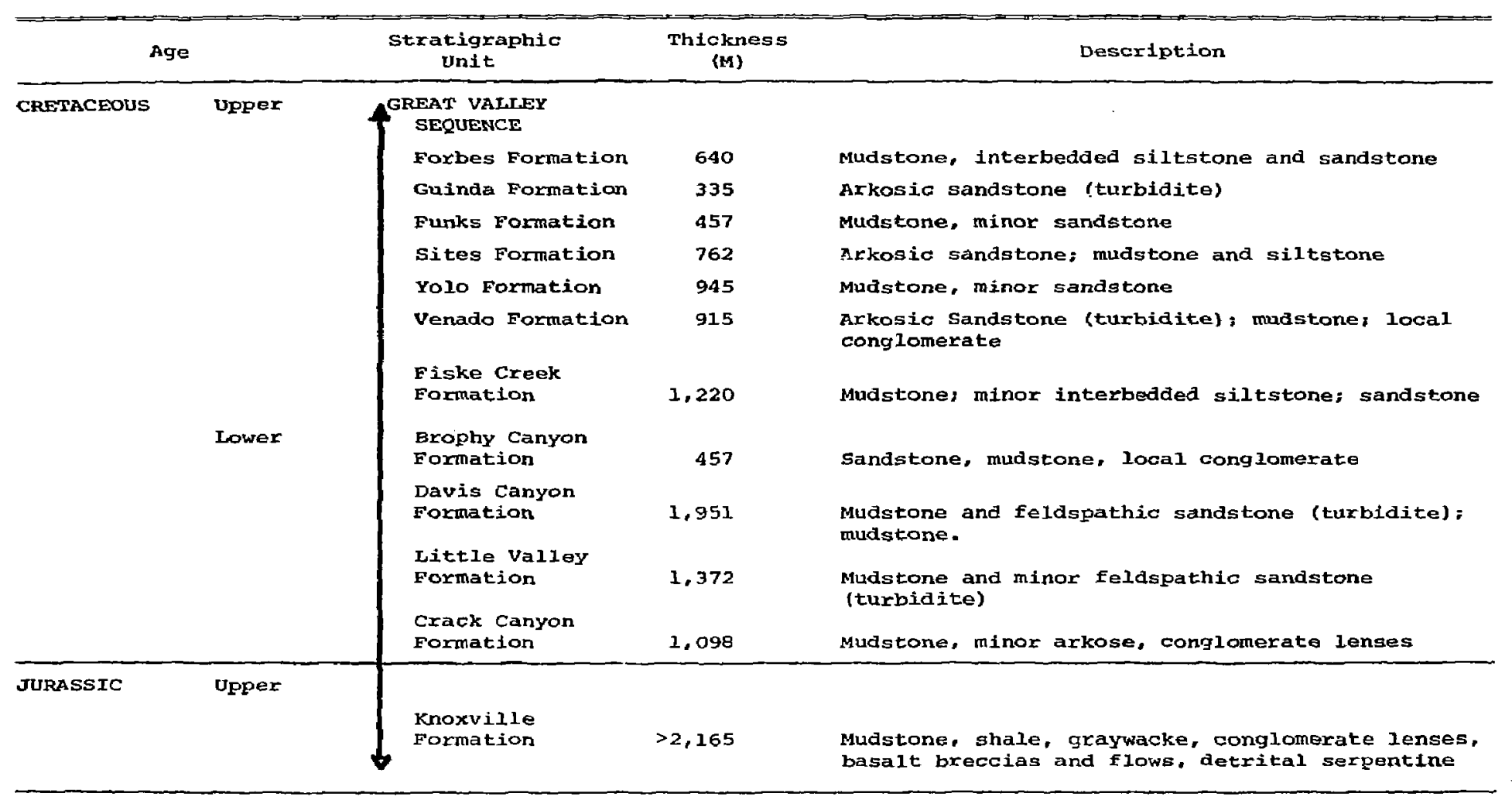




\begin{tabular}{|c|c|c|c|}
\hline Age & $\begin{array}{l}\text { Stratigraphic } \\
\text { Unit }\end{array}$ & $\begin{array}{l}\text { Thickness } \\
\text { (M) }\end{array}$ & Description \\
\hline JURASSIC & $\begin{array}{l}\text { Franciscan } \\
\text { Formation Core }\end{array}$ & 5,000 & $\begin{array}{l}\text { Graywackes, shales, voleantcs (pillow lavas), } \\
\text { chert, limestone, metamorphics }\end{array}$ \\
\hline & $\begin{array}{l}\text { GRANITIC-METAMORPHI } \\
\text { CORE }\end{array}$ & ds & \\
\hline CRETACEOUS & Granitic Plutons & 点 & $\begin{array}{l}\text { Quartz diorite, granodiorite, adamellite, } \\
69-110 \mathrm{~m} . \mathrm{y} \text {. }\end{array}$ \\
\hline PALEOZOIC (?) & Sur Series & & $\begin{array}{l}\text { Gneisses, schists, quartzites, marbles and } \\
\text { granulites; metamorphic miogeoclynal equivalents }\end{array}$ \\
\hline
\end{tabular}




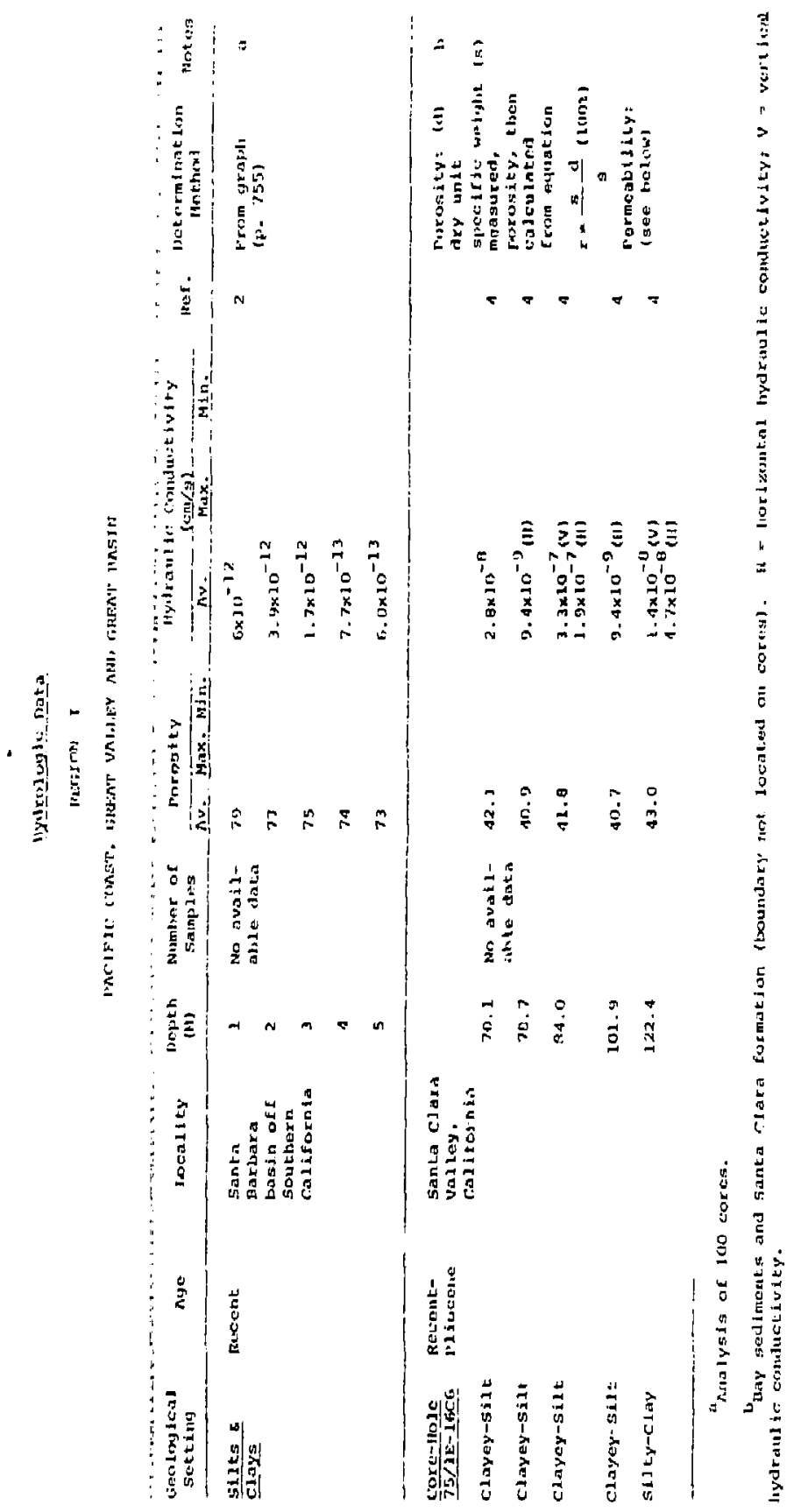


RHaton I (cantinuma)

\begin{tabular}{|c|c|c|c|c|c|c|c|c|c|}
\hline $\begin{array}{l}\text { Geolog lcal } \\
\text { Settiny }\end{array}$ & $n g e$ & Lacalicy & $\begin{array}{l}\text { noptll } \\
\text { (an) }\end{array}$ & $\begin{array}{l}\text { Numbar of } \\
\text { jamples }\end{array}$ & $\frac{\text { Porusiley }}{\text { na. }}$ & 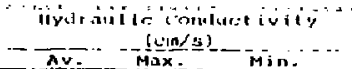 & sens. & $\begin{array}{l}\text { Decermination } \\
\text { Meriod }\end{array}$ & Hotest \\
\hline $\begin{array}{l}\mid \text { care-1lole } \\
75 / 1 \mathrm{E}-16 \mathrm{C6} \mid\end{array}$ & $\begin{array}{l}\text { Recent- } \\
\text { Pliosene }\end{array}$ & $\begin{array}{l}\text { Sonta chara } \\
\text { valley, }\end{array}$ & & $\begin{array}{l}\text { No aval1- } \\
\text { ohle dat.o }\end{array}$ & & & & & \\
\hline clayey-sile & & & 247.5 & & 40.9 & $1.7 \times 10^{-7}(11)$ & 1 & $\begin{array}{l}\text { Prrmcabintey* } \\
\text { Meisured using, }\end{array}$ & \\
\hline clayey-silt & & & 277.0 & & 34.8 & $\begin{array}{l}9.4 \times 10^{-9}(v) \\
1.4 \times 10^{-18}(11)\end{array}$ & 4 & $\begin{array}{l}\text { Woth a ronstait } \\
\text { lwad jerinea- } \\
\text { meter for }\end{array}$ & \\
\hline Clayey-Silt & - & & 2115.9 & & 10. B & $\begin{array}{l}4.7 \times 10^{-9}(v) \\
9.4 \times 10^{-8}(11)\end{array}$ & 4 & 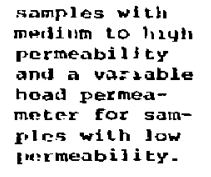 & \\
\hline $\begin{array}{l}\text { Core-11010 } \\
65 / 2 W-24 C 7\end{array}$ & $\begin{array}{l}\text { Recent to } \\
\text { Pliocene }\end{array}$ & $\begin{array}{l}\text { Santa clara } \\
\text { valley. } \\
\text { Callfornia }\end{array}$ & & $\begin{array}{l}\text { No avail- } \\
\text { able data }\end{array}$ & & & 4 & (ristmts as ahrove) & b \\
\hline Clayey-Silt & & & 15.3 & & $4(t . B$ & Ho avallable data & & & \\
\hline Clayey-sile & & & 21.9 & & 39.3 & $\begin{array}{l}4.8 \times 10^{-5}(v) \\
4.3 \times 10^{-5}(I I)\end{array}$ & & & \\
\hline Silty-Clay & & & 276 & & 44.7 & $\begin{array}{l}2.4 \times 10^{-5}(V) \\
3.4 \times 10^{-5}(H)\end{array}$ & & & \\
\hline silty-clay & & & 43.1 & & 40.5 & $\begin{array}{l}1.9 \times 10^{-5}(v) \\
3.3 \times 10^{-5}(\text { II) }\end{array}$ & & & \\
\hline
\end{tabular}

bsire rore hole 75/ikejecr, 
REGIOAN I (continued)

\begin{tabular}{|c|c|c|c|c|c|c|c|c|c|}
\hline Geological & nge & Local Lty & moptli & twuber of & Porosity & 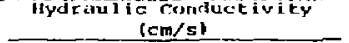 & Kef. & Determination & Nores \\
\hline Sotting & & & & & Av. Max $\mathrm{M111}$ & $\bar{N}=\operatorname{Max} . M L$ & & & \\
\hline $\begin{array}{l}\mid \operatorname{Cos} e-1101 \mathrm{e} \\
65 / 2 \mathrm{H}-24 \mathrm{C})\end{array}$ & $\begin{array}{l}\text { Recent to } \\
\text { pliocene }\end{array}$ & $\begin{array}{l}\text { Santa clara } \\
\text { vallay, } \\
\text { California }\end{array}$ & & $\begin{array}{l}\text { Ho avail- } \\
\text { nblo data }\end{array}$ & & & 4 & & \\
\hline silty-clay & & & 40.8 & & 41.4 & $\begin{array}{l}9.5 \times 10^{-5}(v) \\
9.5 \times 10^{-5}(\text { (I) }\end{array}$ & & & \\
\hline Cliney-silte & & & 54.4 & & 41.0 & $\begin{array}{l}1.9 \times 10^{-4}(v) \\
9.5 \times 10^{-5} \text { (II) }\end{array}$ & & & \\
\hline slley-clay & & & 58.4 & & 36.3 & $\begin{array}{l}2.8 \times 10^{-8}(v) \\
3.3 \times 10^{-8}(11)\end{array}$ & & & \\
\hline slety-cray & & & 67.9 & & 43.9 & $\begin{array}{l}1.9 \times 10^{-7}(v) \\
4.7 \times 10^{-8}(11)\end{array}$ & & & \\
\hline Clayey-511t & & & 93.7 & & 37.2 & $\begin{array}{l}9.4 \times 10^{-9}(v) \\
1.9 \times 10^{-8}(11)\end{array}$ & & & \\
\hline claycy-sile & & & 100.7 & & 37.6 & $\begin{array}{l}3.8 \times 10^{-7} \text { (v) } \\
4.2 \times 10^{-7} \text { (11) }\end{array}$ & & & \\
\hline claycy-silt & & & 124.5 & & 36.4 & $\begin{array}{l}4.9 \times 10^{-9} \text { (v) } \\
1.4 \times 10^{-7} \text { (II) }\end{array}$ & & & \\
\hline Clayey-silt & & & 1.39 .8 & & 39.3 & $\begin{array}{l}4.7 \times 10^{-8}(v) \\
2.4 \times 10^{-7} \text { (11) }\end{array}$ & & & \\
\hline Clayey-silt & & & 166.3 & & 38.5 & $1.4 \times 10^{-8}(\mathrm{H})$ & & & \\
\hline Clayey-Silt & & & 171.8 & & 39.9 & $\begin{array}{l}9.4 \times 10^{-0}(v) \\
9.4 \times 10^{-1}(11)\end{array}$ & & & \\
\hline
\end{tabular}


REGION I (continted)

\begin{tabular}{|c|c|c|c|c|c|c|c|c|c|}
\hline $\begin{array}{l}\text { Geoloytical } \\
\text { setting }\end{array}$ & Age & focality. & Depth & $\begin{array}{l}\text { Numbe- of } \\
\text { Sampies }\end{array}$ & Porestey & $\begin{array}{r}\text { Dyqurante combinitivity } \\
\text { (cm/s) }\end{array}$ & Ref. & Determination & Hotes \\
\hline $\begin{array}{l}\text { ICore-1tole } \\
65 / 2 w-24 c 71\end{array}$ & $\begin{array}{l}\text { Recont to } \\
\text { Pliovene }\end{array}$ & $\begin{array}{l}\text { Santa clara } \\
\text { Valloy, } \\
\text { Call fornia }\end{array}$ & & $\begin{array}{l}\text { No avail- } \\
\text { able data }\end{array}$ & & & 4 & & \\
\hline silty-clay & & & 210.3 & & 37.0 & $\begin{array}{l}3.3 \times 10^{-8} \text { (v) } \\
2.4 \times 10^{-0} \text { (v) }\end{array}$ & & & \\
\hline silty-ciay & & & 227.2 & & 44.9 & $\begin{array}{l}2.4 \times 10^{-0}(\mathrm{~V}) \\
4.7 \times 10^{-8} \text { (II) }\end{array}$ & & & \\
\hline clayey-silt & & & 247.6 & & 37.4 & $\begin{array}{l}1.9 \times 10^{-6}(\mathrm{~V}) \\
4.7 \times 10^{-\mathrm{B}} \text { (II) }\end{array}$ & & & \\
\hline silty-clay & & & 263.8 & & 40.1 & $\begin{array}{l}3.4 \times 10^{-9} \text { (V) } \\
3.4 \times 10^{-8} \text { (II) }\end{array}$ & & & \\
\hline Clayey-Silt & & & 266.0 & & 31.1 & $9.1 \times 10^{-9}(11)$ & & & \\
\hline siley-clay & & & 274.5 & & 39.4 & $1.9 \times 10^{-7}(11)$ & & & \\
\hline clay & & & 281.7 & & 43.7 & $\begin{array}{l}1.9 \times 10^{-7}(v) \\
3.3 \times 10^{-7}(1)\end{array}$ & & & \\
\hline$\frac{\text { Care-13ole }}{24 / 26-36 A 2}$ & $\begin{array}{l}\text { Upper } \\
\text { P1 ioceno to } \\
\text { Plfocente (T) }\end{array}$ & $\begin{array}{l}\text { Tulare- } \\
\text { Wasco nrea, } \\
\text { Callfornia }\end{array}$ & & $\begin{array}{l}\text { No avafi- } \\
\text { able data }\end{array}$ & & & 4 & (same as above) & $c$ \\
\hline clayey-silt & & & 257.2 & & 40.9 & $1.4 \times 10^{-7}(v)$ & & & \\
\hline sil.t & & & 259.9 & & 46.0 & $2.8 \times 10^{-7}(\mathrm{v})$ & & & \\
\hline
\end{tabular}

Farine strata. 


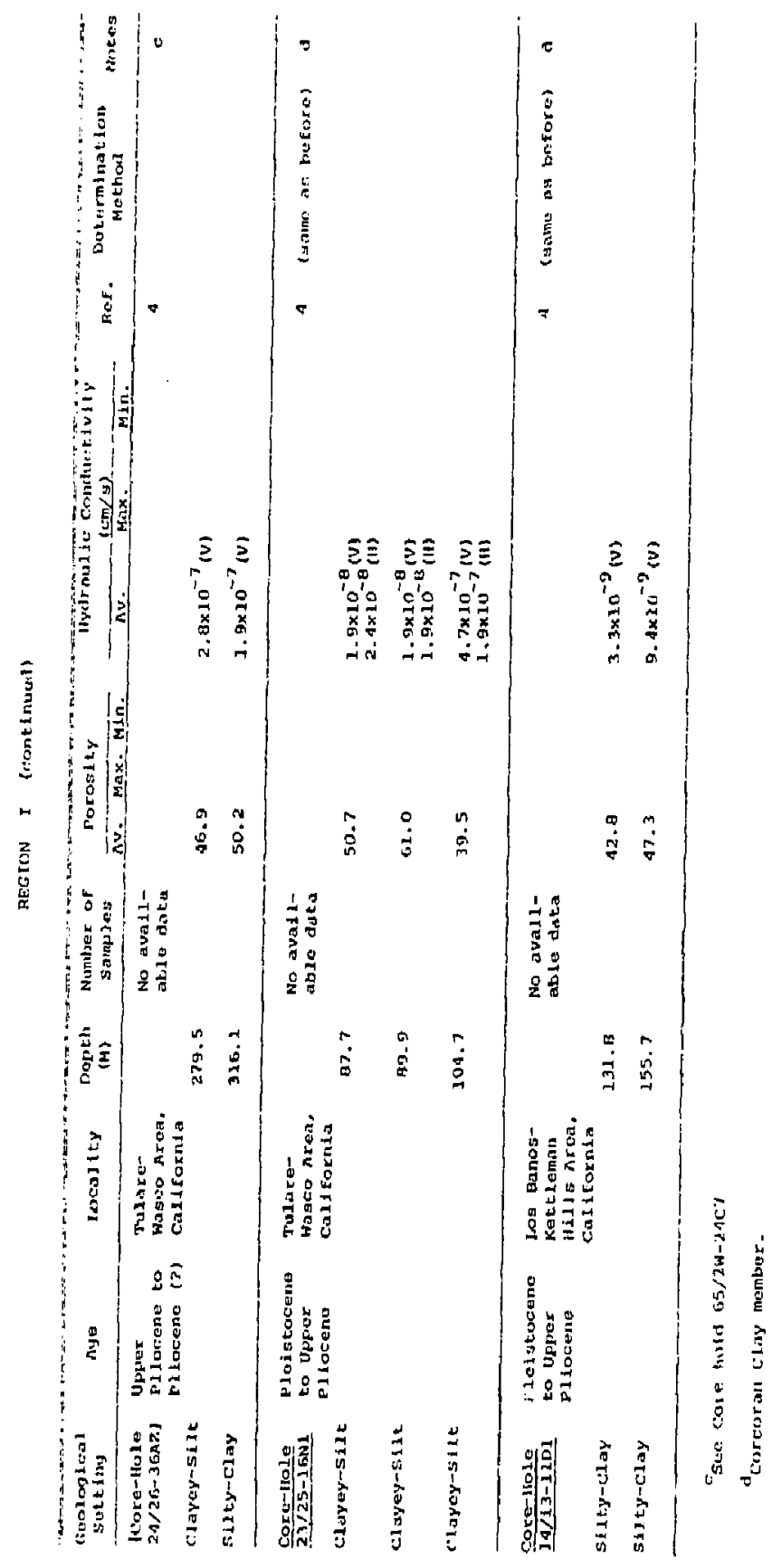




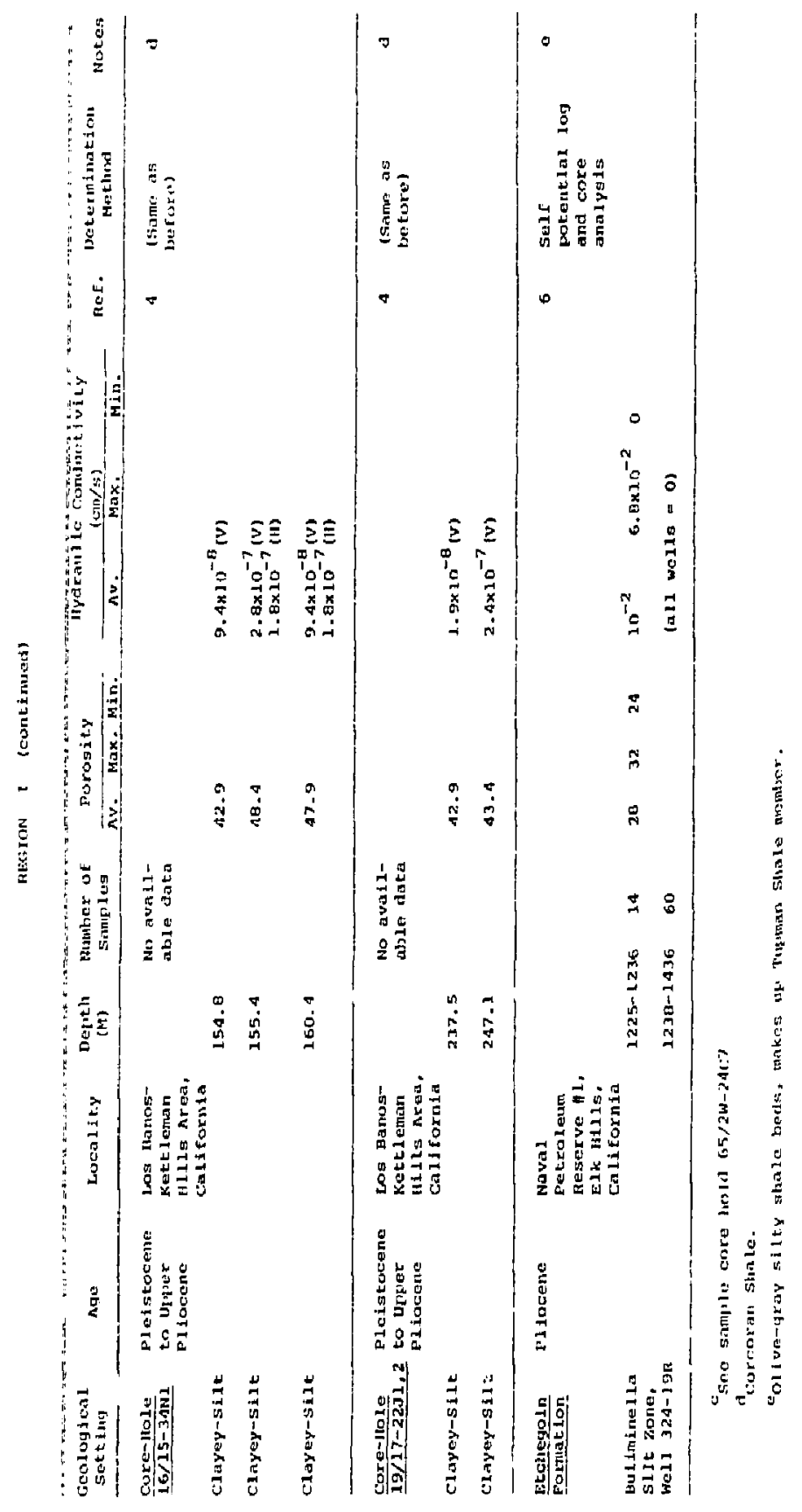


Reston I (contluner)

\begin{tabular}{|c|c|c|c|c|c|c|c|c|c|c|}
\hline $\begin{array}{l}\text { Gealorgical } \\
\text { Setting }\end{array}$ & $\mathbf{A g e}$ & Local ley & $\begin{array}{l}\text { Dejpth } \\
\text { (H) }\end{array}$ & $\begin{array}{l}\text { Number of } \\
\text { Samplas }\end{array}$ & \multicolumn{2}{|c|}{ Porosity } & $\begin{array}{l}\text { Ifydranl ic Conductivitey } \\
\qquad(\mathrm{cm} / \mathrm{s})\end{array}$ & Ref. & $\begin{array}{l}\text { netorminat ion } \\
\text { MeLheal }\end{array}$ & Notes \\
\hline $\begin{array}{l}\text { Roef Ridge } \\
\text { Shaje }\end{array}$ & $\begin{array}{l}\text { Midd le to } \\
\text { Iste Miocents }\end{array}$ & $\begin{array}{l}\text { Maval } \\
\text { Petroleum } \\
\text { Reservo "1, } \\
\text { Ekk bilis. } \\
\text { California }\end{array}$ & $1439-1482$ & 3.3 & $\therefore$. & & (all wells $=0)$ & 6 & $\begin{array}{l}\text { Sclf } \\
\text { lotantial loy } \\
\text { ant core } \\
\text { andiynis }\end{array}$ & $\mathbf{E}$ \\
\hline $\begin{array}{l}\text { Wonterey } \\
\text { Shale and } \\
\text { Steveng } \\
\text { ofl zong }\end{array}$ & $\begin{array}{l}\text { MLddle to } \\
\text { Iate Micothe }\end{array}$ & $\begin{array}{l}\text { Naval } \\
\text { Petroleut } \\
\text { Reserve } 1, \\
\text { Elk Hills. } \\
\text { Californla }\end{array}$ & & & & & & $\sigma$ & (Sasu: as alusve) & 9 \\
\hline $\begin{array}{l}\text { H-2ONE } \\
\text { 35B-22R }\end{array}$ & & & $2220-2221$ & 4 & 17 & 20 & $1.1 \times 10^{-2} 2.3 \times 10^{-2} 9 \times 10^{-3}$ & & & \\
\hline $378-228$ & & & 2095 & 2 & 14 & 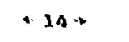 & $3 \times 10^{-4}$ & & & \\
\hline $\begin{array}{l}\text { n-ZONE } \\
342-36\end{array}$ & & & $2139-2150$ & $\mathbf{a}$ & 20 & 25 & $2.2 \times 10^{-2} 7.3 \times 10^{-2} \mathrm{o}$ & & & \\
\hline $362-36$ & & & $2125-2143$ & & 20 & 29 & $1.1 \times 10^{-2} 3.6 \times 10^{-2} 0$ & & & \\
\hline $302-3 c$ & & & $2110-2153$ & 20 & 15. & 19 & $1 \times 10^{-3}$ & & & \\
\hline
\end{tabular}

f Brown clayey and silty shale bods.

grom to gray diatomaceous gitstunes, and lesser amount of $n$-G, 911 ty, partiy sillerous sthale, and very fine to medium grained silly sandstone. 
FEGIIN I [cuntimat)

\begin{tabular}{|c|c|c|c|c|c|c|c|c|c|c|c|c|}
\hline \multirow{2}{*}{ 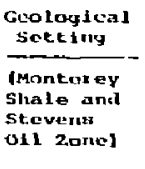 } & mige & tacianltey & $\begin{array}{l}\text { Detith } \\
\text { (M) }\end{array}$ & $\begin{array}{l}\text { Nhwituer of } \\
\text { s.imfiles los }\end{array}$ & \multicolumn{3}{|c|}{ Porosity } & Myelrae & \multicolumn{2}{|c|}{ 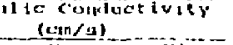 } & Bef. Teecormlnatlosn & Hutess \\
\hline & $\begin{array}{l}\text { Mislate to } \\
\text { tate Miocene }\end{array}$ & 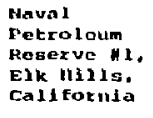 & & & & & & & & & 6 & $a$ \\
\hline 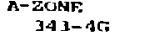 & & & $1984-2044$ & 9 & 16 & 20 & $1 x$ & $6 \times 10^{-4}$ & $4 \times 10^{-3}$ & 0 & & $n$ \\
\hline $3 \Delta z-A t ;$ & & & $2055-206 \%$ & 13 & 15 & 21 & a & $3 \times 3 w^{-3}$ & $1.1 \times 10^{-2}$ & 0 & & \\
\hline $374-22 \pi$ & & & $2099-2204$ & 50 & 17 & 26 & 12 & $1.8 \times 10^{-2}$ & $3 \times 10^{-2}$ & $u$ & & \\
\hline $322-25 R$ & & & $1647-1704$ & 19 & 16 & 23 & B & $2 \times 10^{-3}$ & $1 \times 10^{-2}$ & 0 & & \\
\hline $112-25 \mathrm{R}$ & & & $1962-196.3$ & 3 & 20 & 23 & 14 & $1.4 \times 10^{-1}$ & $3 \times 10^{-1}$ & $1 \times 10^{-3}$ & & \\
\hline $344-20 R$ & & & $1330-1876$ & 10 & 19 & 36 & 13 & $5.2 \times 10^{-1}$ & $1.9 \times 10^{-1}$ & v & & \\
\hline $526-28 \mathrm{~K}$ & & & $1571-1576$ & 5 & 23 & 25 & 18 & $2 \times 10^{-3}$ & $6 \times 10^{-3}$ & $\mathbf{a}$ & & \\
\hline $344-305$ & & & $2211-2200$ & 14 & 14 & 21 & 9 & $1 \times 10^{-3}$ & $5 \times 10^{-3}$ & o & & \\
\hline $542-315$ & & & $1530-1537$ & $\mathbf{s}$ & 23 & 30 & 7 & $2 \times 10^{-3}$ & $5 \times 10^{-3}$ & o & & \\
\hline $366-325$ & & & $170 G-1757$ & 33 & 14 & 23 & 10 & $1.4 \times 10^{-2}$ & $7.1 \times 10^{-2}$ & 0 & & \\
\hline
\end{tabular}


RERTiche I fountintiod

\begin{tabular}{|c|c|c|c|c|c|c|c|c|c|c|c|c|c|}
\hline $\begin{array}{l}\text { Geolougieal } \\
\text { Secting }\end{array}$ & $n: \mathbf{J}^{2}$ & tocolity & $\begin{array}{l}\text { vepreh } \\
(+N)\end{array}$ & $\begin{array}{l}\text { Nutuher of } \\
\text { Satnpilos }\end{array}$ & 萑: & Most & inin. & Nydrant? & 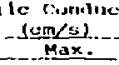 & -lbuty & Ret. & $\begin{array}{l}\text { Wotermination } \\
\text { Mettiod }\end{array}$ & Protes \\
\hline $\begin{array}{l}\text { EMornerey } \\
\text { Shale anil } \\
\text { Stovens } \\
\text { Did Zonel }\end{array}$ & $\begin{array}{l}\text { Mladic to } \\
\text { 1ate Mlocene }\end{array}$ & $\begin{array}{l}\text { Naval } \\
\text { Eetroleum } \\
\text { Rcsorve } \\
\text { Exk hils, } \\
\text { Colifornia }\end{array}$ & & & & & & & & & 6 & & h. \\
\hline $\begin{array}{l}\text { A-2ONE } \\
\text { JeB-325 }\end{array}$ & & & $1866-1890$ & 7 & 10 & 19 & 16 & $4 \times 10^{-5}$ & $2 \times 30^{-1}$ & $n$ & & & \\
\hline $345-335$ & & & $2076-2086$ & 13 & 10 & 23 & 10 & $9 \times 10^{-3}$ & $2.2 \times 10^{-2}$ & $n$ & & & \\
\hline $337-345$ & & & $20320-2021$ & 2 & 160 & 19 & 13 & $3.5 \times 10^{-j}$ & $1 \times 10^{-3}$ & 0 & & & \\
\hline $144-345$ & & & $2137-2152$ & 17 & 17 & 20 & 13 & $3 \times 10^{-3}$ & $1.5 \times 10^{-2}$ & 0 & & & \\
\hline $126-355$ & & & $2027-2043$ & 19 & 17 & 22 & 11 & $4.6 \times 10^{-3}$ & $6 \times 10^{-7}$ & 0 & & & \\
\hline $344-355$ & & & $2090-2095$ & B & 17 & 26 & .13 & $5.9 \times 10^{-2}$ & $2.5 \times 10^{-1}$ & $6 \times 10^{-3}$ & & & \\
\hline $184-355$ & & & $216 G-2172$ & ᄀ & 19 & 21 & 16 & $1.2 \times 10^{-2}$ & $1.5 \times 10^{-2}$ & 0 & & & \\
\hline $17-142$ & & & $1513-1510$ & A & 24 & 24 & 19 & $2 \times 10^{-3}$ & $1.2 \times 10^{-2}$ & u & & & \\
\hline $\begin{array}{l}\text { B-zodis: } \\
142-2 G\end{array}$ & & & $2218-2420$ & 415 & 22 & 32 & 9 & $7.5 \times 10^{-5}$ & $7.9 \times 10^{-4}$ & o & & & $\mathbf{i}$ \\
\hline $3: 42-3 G$ & & & $2152-2326$ & 113 & 23 & $3 \mathbf{3}$ & 8 & $1 \times 10^{-4}$ & B. $7 \times 10^{-4}$ & o & & & \\
\hline
\end{tabular}

tsece previous pacje.

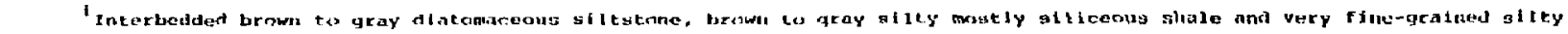
sisudet one. 
REGION I (continuen)

\begin{tabular}{|c|c|c|c|c|c|c|c|c|c|c|c|c|c|}
\hline \multirow{2}{*}{$\begin{array}{l}\text { Geslogical } \\
\text { Seting }\end{array}$} & \multirow[t]{2}{*}{ AyE } & \multirow{2}{*}{ lacality } & \multirow{2}{*}{$\begin{array}{l}\text { Depth } \\
\text { (M) }\end{array}$} & \multirow{2}{*}{$\begin{array}{l}\text { Mwriber of } \\
\text { Sianplos }\end{array}$} & \multicolumn{3}{|c|}{ Porosity } & \multicolumn{3}{|c|}{$\begin{array}{l}\text { "yaraibite comblinetivity } \\
(\mathrm{cm} / \mathrm{s})\end{array}$} & \multirow{2}{*}{ Ref. } & \multirow{2}{*}{$\begin{array}{l}\text { Deternination } \\
\text { Method }\end{array}$} & \multirow{2}{*}{ notes } \\
\hline & & & & & nY. & 복. & Mill. & Av. & Max. & MIn. & & & \\
\hline $\begin{array}{l}\text { CHonterey } \\
\text { Stanie atnl } \\
\text { Stevens } \\
\text { oll zoliel }\end{array}$ & $\begin{array}{l}\text { Middle to } \\
\text { Lete Mroceme }\end{array}$ & $\begin{array}{l}\text { Naval } \\
\text { Petroleun } \\
\text { Reserve } 1, \\
\text { Elk Hills, } \\
\text { Callfornia }\end{array}$ & & & & & & & & & 6 & & i \\
\hline $\begin{array}{l}\text { G-ZUNE } \\
\text { 3B2-3G }\end{array}$ & & & $2168-23.16$ & 402 & 22 & 20 & 12 & $1.8 \times 10^{-4}$ & $1.2 \times 10^{-3}$ & 0 & & & \\
\hline $343-46$ & & & $2064-2221$ & 247 & 22 & 29 & 14 & $9.13 \times 10^{-5}$ & $7.9 \times 10^{-4}$ & 0 & & & \\
\hline $346-4 G$ & & & $2211-2334$ & 121 & 17 & 26 & 6 & $3.6 \times 10^{-5}$ & $3 \times 10^{-4}$ & o & & & \\
\hline $382-66$ & & & $2110-2284$ & 155 & 22 & 30 & 11 & 9. $1 \times 10^{-5}$ & $1.9 \times 10^{-3}$ & $n$ & & & \\
\hline $321-56$ & & & $1030-1940$ & 178 & 22 & 29 & 13 & $1 \times 10^{-4}$ & $6.1 \times 10^{-4}$ & $\mathbf{0}$ & & & \\
\hline $362-56$ & & & $1976-2063$ & 145 & 23 & 29 & 14 & $6.5 \times 10^{-5}$ & $6.9 \times 10^{-4}$ & o & & & \\
\hline $342-6 x$ & & & $2205-2206$ & 2 & 15 & 16 & 14 & $3.4 \times 10^{-6}$ & $4.3 \times 10^{-6}$ & $2.6 \times 10^{-6}$ & & & \\
\hline J42-GG & & & $2236-2237$ & 3 & 13 & 14 & 12 & $5.1 \times 10^{-6}$ & $1.1 \times 10^{-5}$ & $1.7 \times 10^{-6}$ & & & \\
\hline $362-66$ & & & $2141-2145$ & 3 & 19 & 21 & 18 & $9.4 \times 10^{-6}$ & $1.7 \times 10^{-5}$ & 9. $6 \times 10^{-7}$ & & & \\
\hline $322-23 R$ & & & $2709-2719$ & 28 & $\mathbf{B}$ & 14 & g & $2.9 \times 10^{-7}$ & B. $6 \times 10^{-7}$ & $\mathbf{0}$ & & & \\
\hline $38 u-2314$ & & & $1076-1991$ & 120 & 23 & 30 & 16 & $3.5 \times 10^{-5}$ & $5.5 \times 10^{-4}$ & 0 & & & \\
\hline $322-25 \mathrm{H}$ & & & $1711-1771$ & 63 & 21 & 26 & 12 & $1.6 \times 10^{-5}$ & $1.8 \times 10^{-4}$ & $\mathbf{o}$ & & & \\
\hline $335-25 R$ & & & $1641-1700$ & 75 & 22 & 32 & 16 & $2.5 \times 10^{-5}$ & $1.8 \times 10^{-4}$ & $\mathbf{0}$ & & & \\
\hline
\end{tabular}

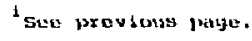


Roficion $t$ (continued)

\begin{tabular}{|c|c|c|c|c|c|c|c|c|c|c|c|c|c|}
\hline \multirow{2}{*}{ 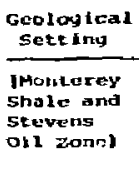 } & Ayn & Lacesl i ty & $\begin{array}{c}\text { Depteh } \\
\text { (IM) }\end{array}$ & $\begin{array}{l}\text { Mumber of } \\
\text { Samplos }\end{array}$ & \multicolumn{3}{|c|}{ Poronity } & \multicolumn{3}{|c|}{$\begin{array}{l}\text { Hydraulfe: CondteleLivity } \\
\end{array}$} & Ref. & $\begin{array}{l}\text { Determination } \\
\text { Methos }\end{array}$ & notes \\
\hline & $\begin{array}{l}\text { Midule to } \\
\text { Late Miocene }\end{array}$ & $\begin{array}{l}\text { Haval } \\
\text { Putraleur } \\
\text { Reserve } \\
\text { Elk Iilis. } \\
\text { Califurata }\end{array}$ & & & & & & & & & G. & & \\
\hline $\begin{array}{l}\text { B-zONTE } \\
34 \mathrm{~S}-25, \mathrm{~K}\end{array}$ & & & $1679-1767$ & 60 & 23 & ;1 & 14 & $3.0 \times 10^{-5}$ & $1.2 \times 20^{-4} \mathrm{c}$ & o & & & \\
\hline $36,2-25 R$ & & & $1842-1909$ & 70 & 22 & 30 & 11 & $1.4 \times 20^{-5}$ & $9 \times 10^{-5}$ & D & & & \\
\hline $3 G \theta-25 k$ & & & $1589-1505$ & 6 & 21 & 26 & 17 & $5.8 \times 10^{-5}$ & $1.5 \times 10^{-4}$ & $0.6 \times 10^{-6}$ & & & \\
\hline $332-26 \mathrm{~F}$ & & & $1687-1773$ & 115 & 21 & 29 & $\theta$ & $2.1 \times 10^{-5}$ & $5.4 \times 10^{-4}$ & n & & & \\
\hline $382-26.7$ & & & $1813-1912$ & 5G & 21 & 27 & 13 & $3.3 \times 10^{-5}$ & $2.6 \times 10^{-4}$ & $\mathbf{o}$ & & & \\
\hline $5>G-20 R$ & & & 16.34 & $\mathbf{l}$ & 20 & 2 & & $1.2 \times 10^{-5}$ & $1.2 \times 10^{-7}$ & -5 & & & \\
\hline $526-28 R$ & & & 1656 & 1 & 25 & 2 & & $1.9 \times 10^{-4}$ & $1.9 \times 10^{-}$ & -4 & & & \\
\hline $3+2-34 k$ & & & $2482-2529$ & 10 & 13 & 19 & 7 & $3.6 \times 10^{-7}$ & $2.0 \times 10^{-6}$ & 0 & & & \\
\hline $3 G 2-36 k$ & & & $1668-1771$ & 65 & 23 & 32 & 17 & $5.9 \times 10^{-5}$ & $4.5 \times 10^{-4}$ & $0.6 \times 10^{-7}$ & & & \\
\hline $326-30 s$ & & & $1740-1830$ & 63 & 24 & 31 & 14 & $1.4 \times 10^{-5}$ & $7.6 \times 10^{-5}$ & o & & & \\
\hline $388-105$ & & & $1953-2025$ & 4 & 17 & $2 n$ & 14 & $1 \times 10^{-5}$ & $2.7 \times 10^{-5}=$ & $2.6 \times 30^{-6}$ & & & \\
\hline $322-115$ & & & $1548-1663$ & 30 & 21 & 29 & 11 & $2.3 \times 10^{-5}$ & $1.1 \times 10^{-4}$ & $0.6 \times 10^{-7}$ & & & \\
\hline $325-315$ & & & $1716-1769$ & 50 & 22 & 29 & 17 & $1.1 \times 10^{-4}$ & $4.5 \times 10^{-4}$ & $\mathbf{D}$ & & & \\
\hline
\end{tabular}


REr,tor) I (contimurit)

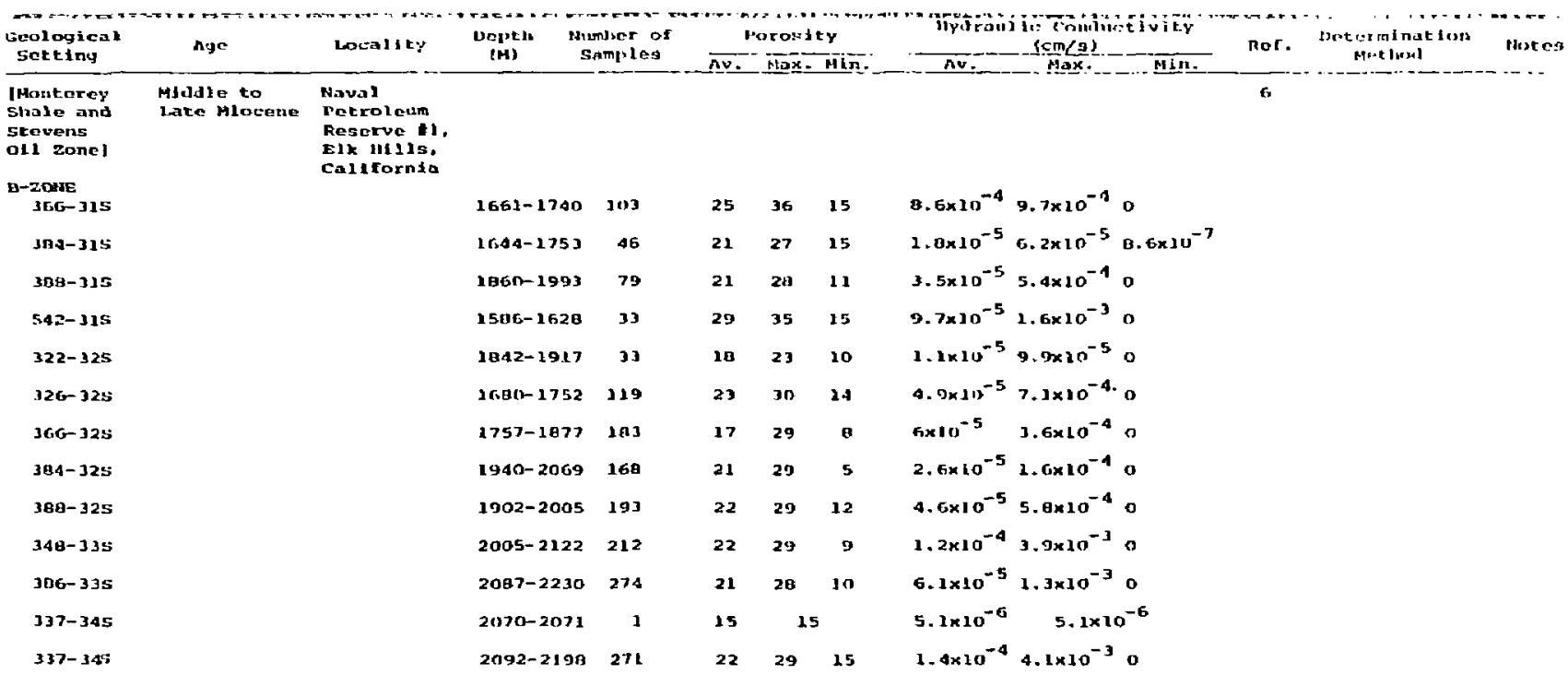


Hagron I (eontinued)

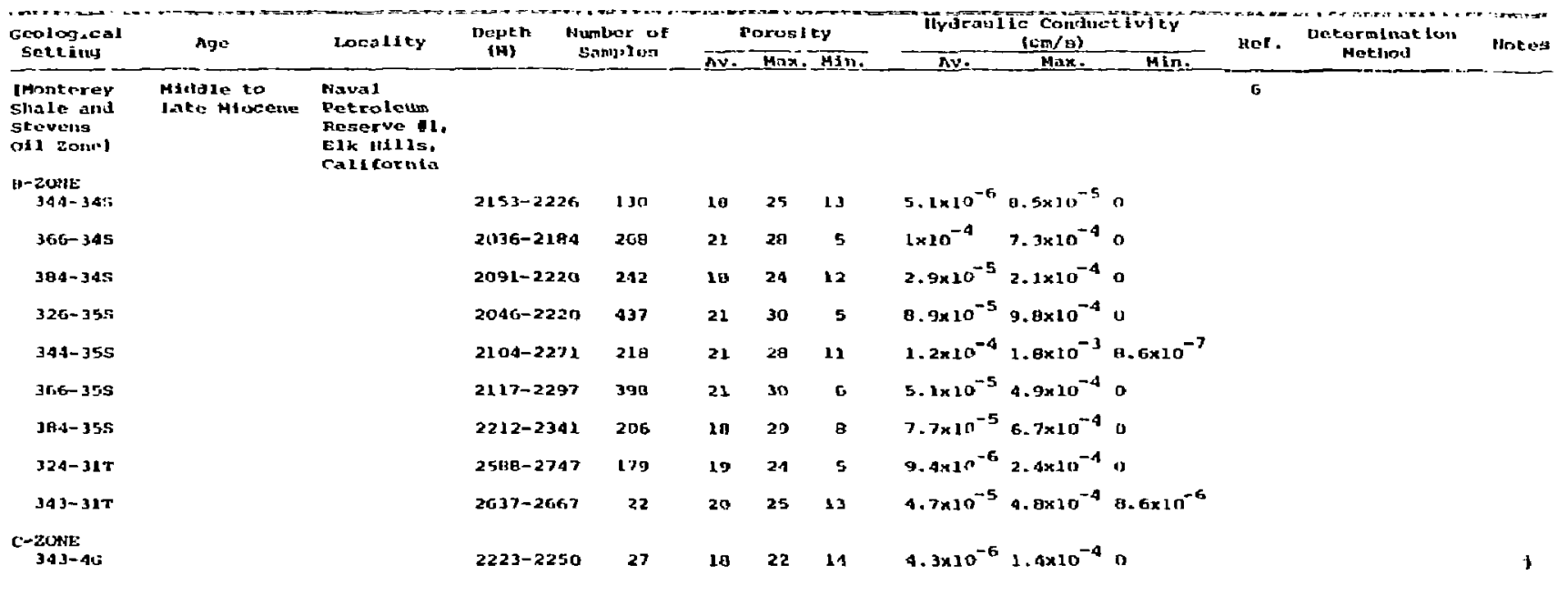

Gray. jortly gillecous shale that fnelubus some intorbedded dlatomaceous siltstone, some thin aandstone and dulomite layera. 
REGIOA I (conefinued)

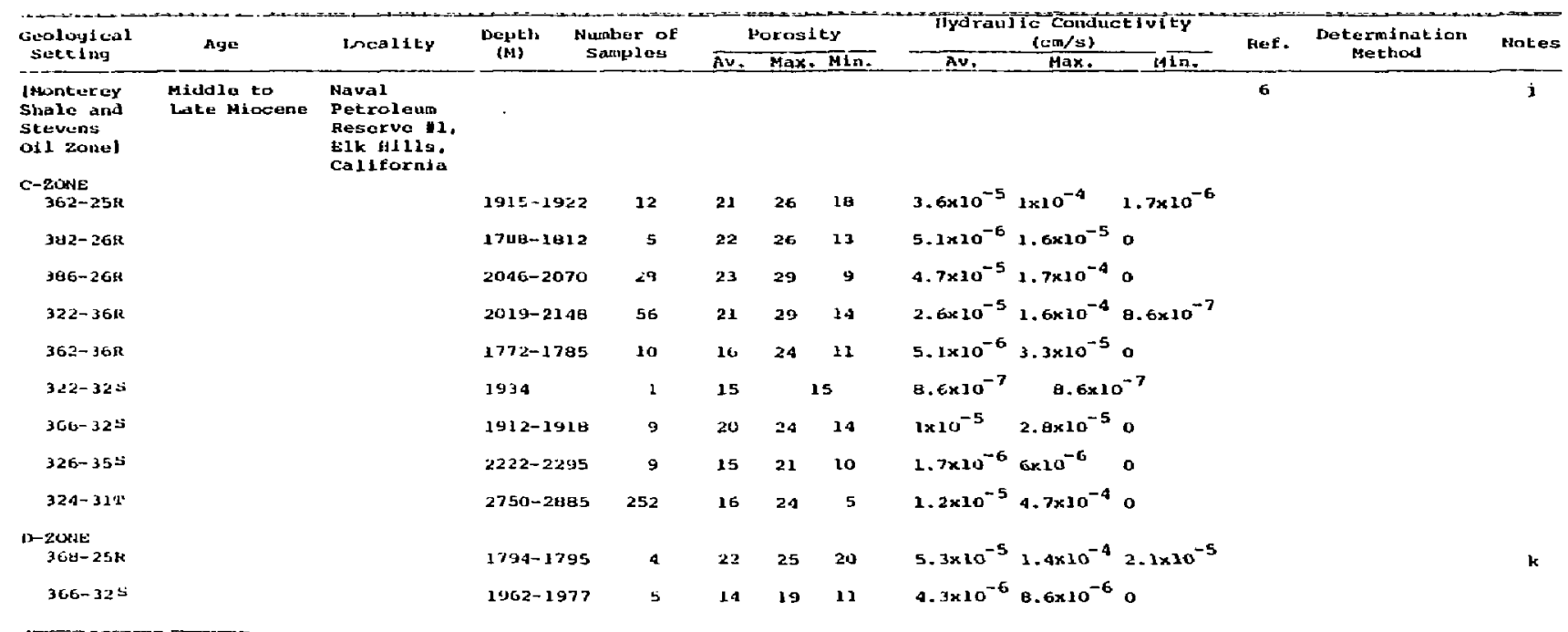

bice prequinas parage.

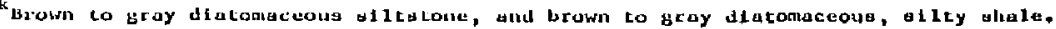


RFGLOS I (Lontinued)

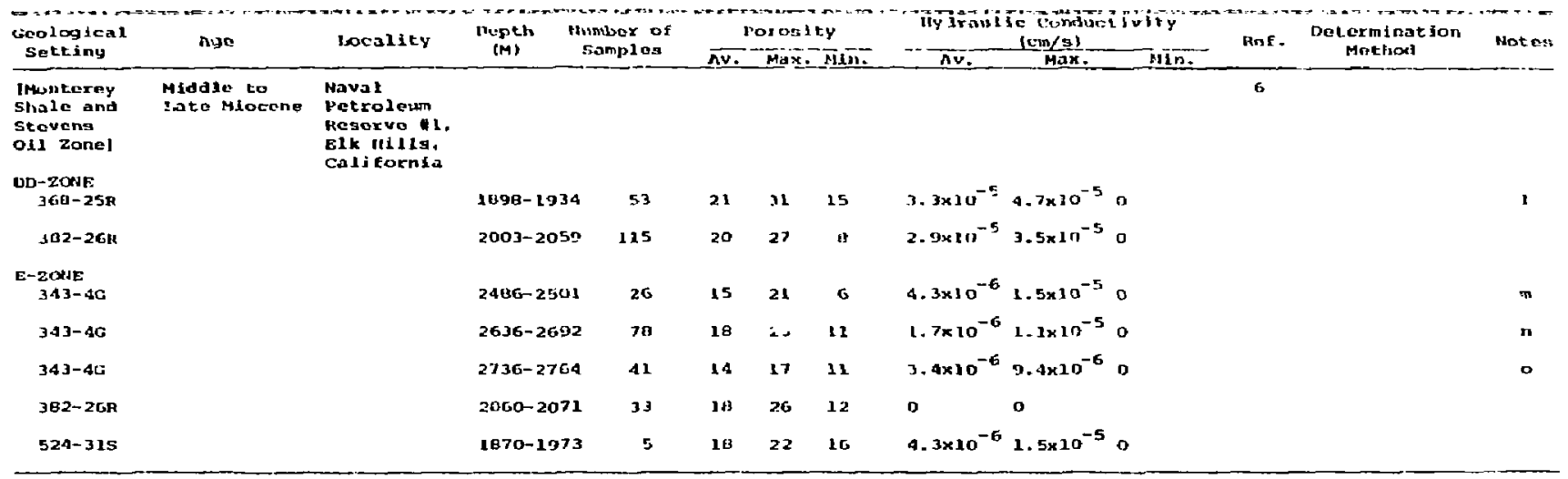

purowe to dark allty shale, dark-gray silestone, and in tha lower half, some ligitit gray silty sandstone.

Mmedlum to Jark gray sillegous and cherty slato abundant in lower part.

"Medien to Jark gray, partly sandy slltstong abindant in middlo and mpper ports.

Osoveral thin beds of fine-grained sanüstone axe present in upper part. 
let:CiCH) I (continute1)

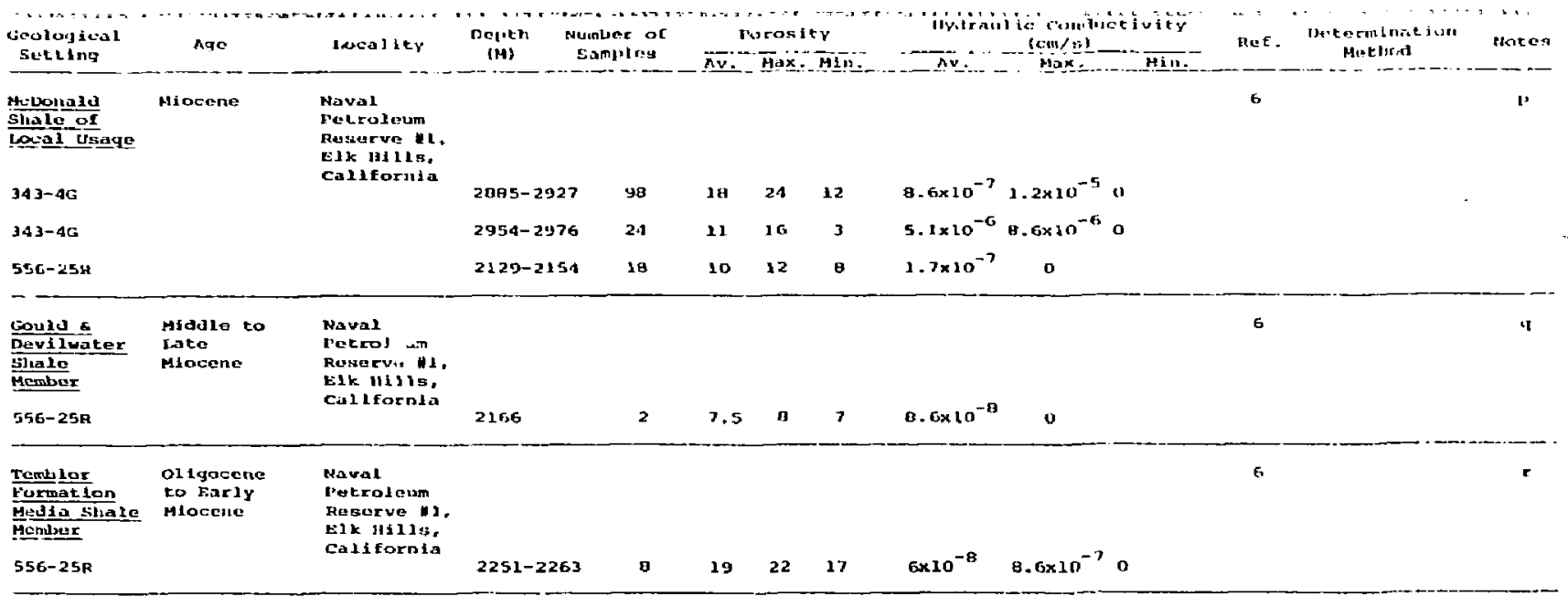

PMassive bromn siley ahale.

Ysilficeous shale secuones.

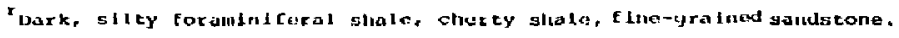


HESTON I (Continued)

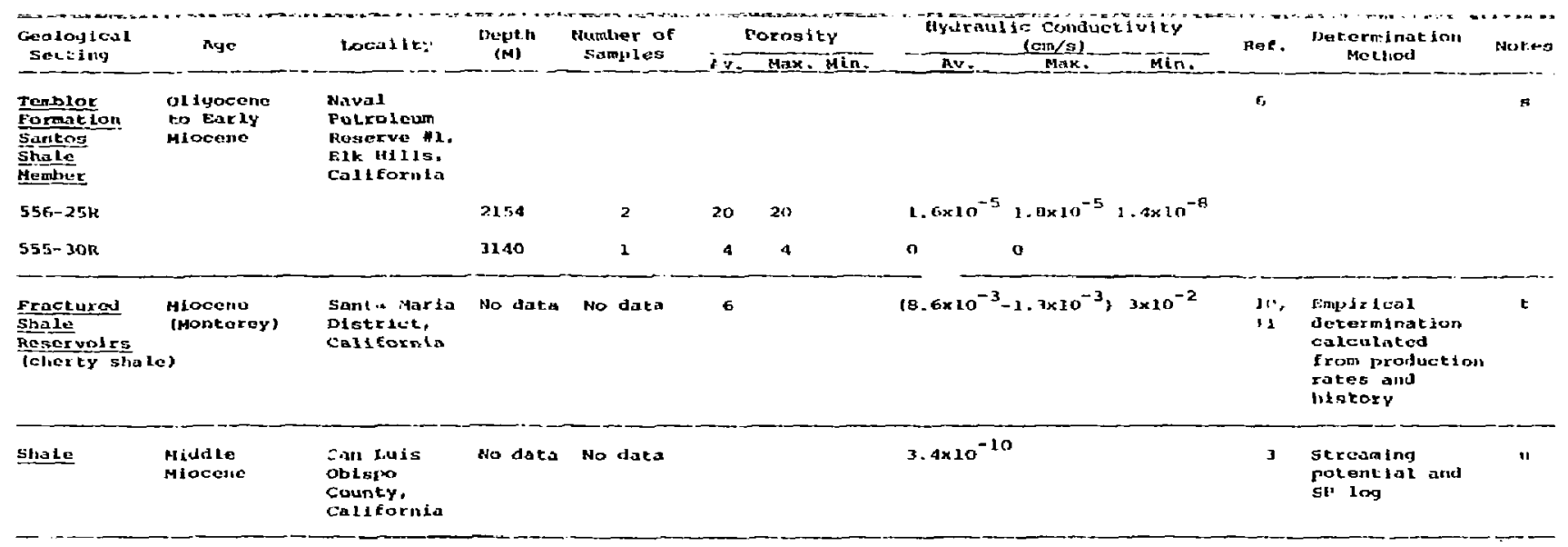

- b-lyht-griy to tan atid dark brown shato atuat stltestone.

Tractuking the result of siltinkaye durling chemical changes.

Me.saured unang a O. 3N MaCl solution. 


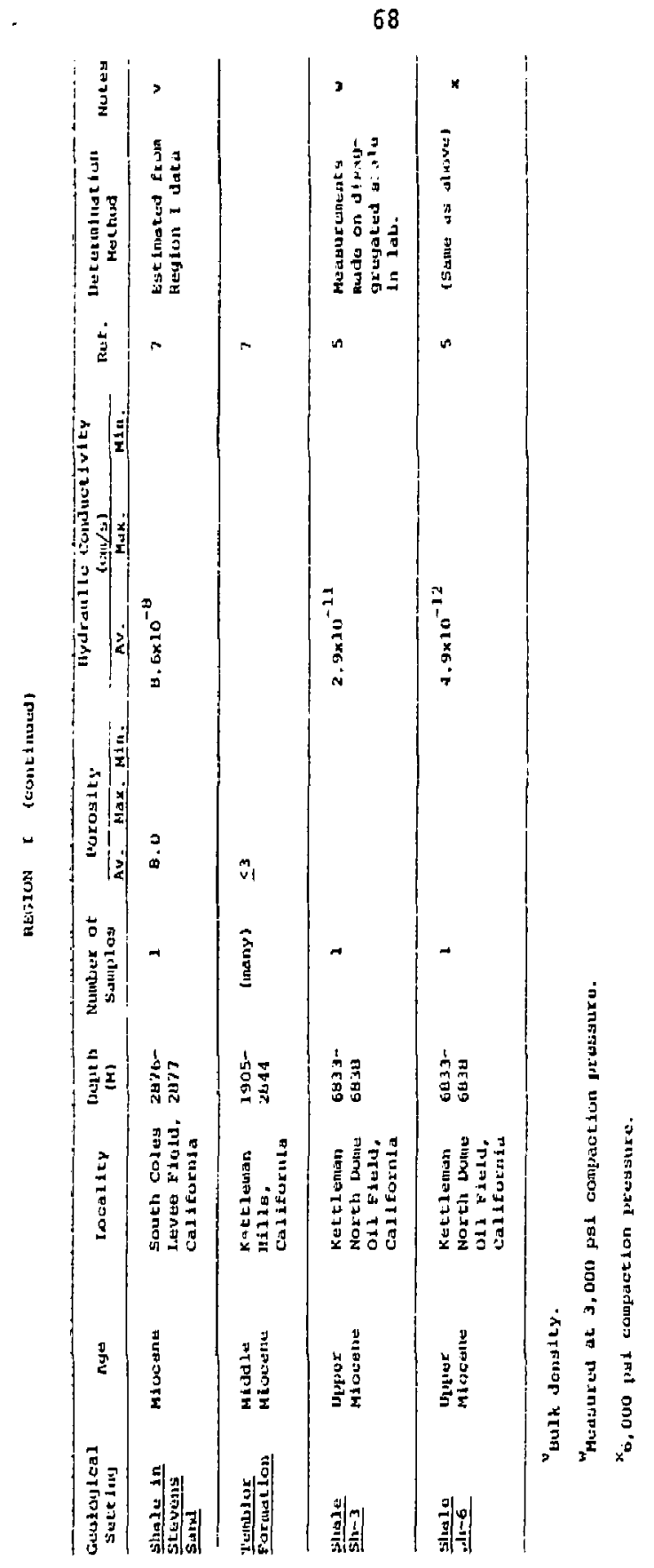




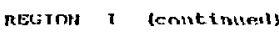

\begin{tabular}{|c|c|c|c|c|c|c|c|c|c|}
\hline $\begin{array}{l}\text { Cooloyjeal } \\
\text { Socting }\end{array}$ & nije & toral tly & $\begin{array}{l}\text { Buptl } \\
\text { (N) }\end{array}$ & $\begin{array}{l}\text { Nimber of } \\
\text { Samplas }\end{array}$ & Forosily & $\begin{array}{c}\text { Tyrirainife Cundurtivity } \\
\text { (cmos) }\end{array}$ & Ruf. & $\begin{array}{l}\text { Dortormination } \\
\text { Metiond }\end{array}$ & Notert: \\
\hline$\frac{\text { Shale }}{\text { Shr-g }}$ & $\begin{array}{l}\text { Upper } \\
\text { stociene }\end{array}$ & $\begin{array}{l}\text { Kettleman } \\
\text { North Dume } \\
\text { oll Fiald. } \\
\text { califarnla }\end{array}$ & $\begin{array}{l}5833- \\
50338\end{array}$ & 1 & & $13.1 .10^{-3}$ & 5 & 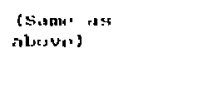 & $r$ \\
\hline
\end{tabular}

\begin{tabular}{|c|c|c|c|c|c|c|c|c|}
\hline$\frac{\text { Solunas }}{\text { sha1e* }}$ & novene & $\begin{array}{l}\text { Coleta } \\
\text { landing, } \\
\text { California }\end{array}$ & couterop & 33.3 & 8. $7 \times 10^{-4}$ & $\mathrm{n}$ & 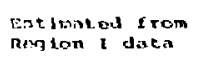 & 2 \\
\hline Gror Thagen & $\begin{array}{l}\text { Uppor } \\
\text { Eocerse- } \\
\text { Oliyocene }\end{array}$ & $\begin{array}{l}\text { Nort] } \\
\text { BeIridge, } \\
\text { California }\end{array}$ & & $\begin{array}{l}3.9- \\
4.3\end{array}$ & & 2 & & \\
\hline
\end{tabular}

Y. $3 i$ compaction presgure.

zoips 55.5, in stratiun.

evensity: $1.78 \mathrm{~g} / \mathrm{em}^{3} \mathrm{dry}: 2.11 \mathrm{~g} / \mathrm{cm}^{3}$ sat.

-Density: $2.56-2.63 \mathrm{~g} / \mathrm{cm}^{3} \mathrm{dry}, 2.60-2.67 \mathrm{~g} / \mathrm{cm}$ ? sat. 


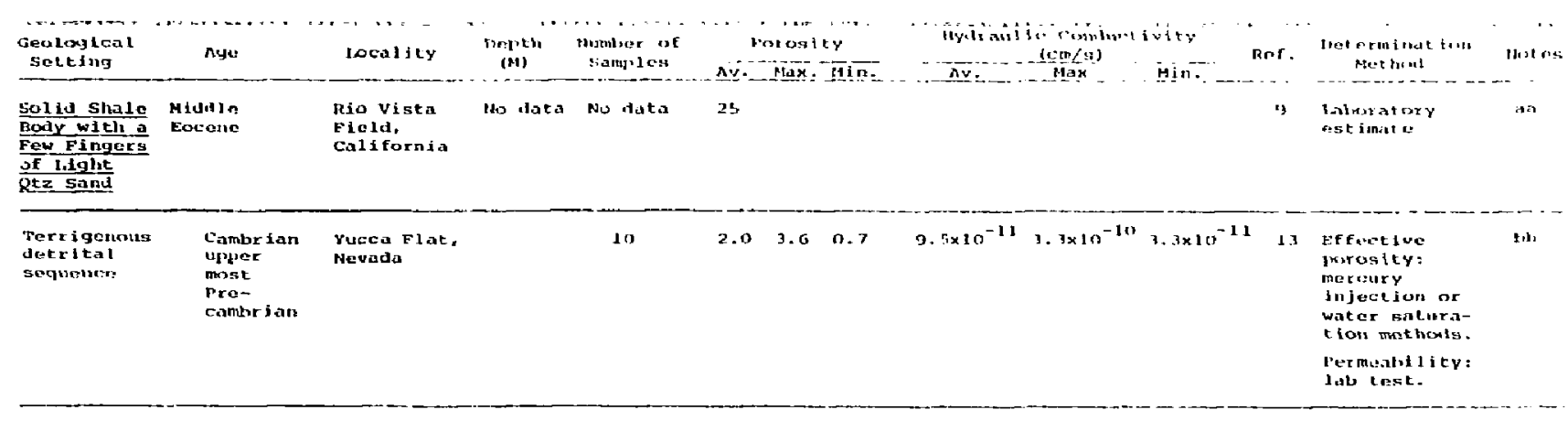

adin elongate dome trendiag NW-SE, has a vory complfwater fault pattern (Midland 5 zone).

bb siltstolle and argillite from well kg-68. 
RE,GION I

OTHER PROPERTIES

\begin{tabular}{|c|c|c|c|c|c|}
\hline Formation & Age & Locality & $\begin{array}{l}\text { Flow Rate } \\
\text { Ml/hr/l000 psi }\end{array}$ & Reference & Notes \\
\hline Shale & $\begin{array}{l}\text { Upper } \\
\text { Miocene }\end{array}$ & $\begin{array}{l}\text { Kettleman North } \\
\text { Dome Oil Field, } \\
\text { Califormia } \\
\text { Well \#E5 (29-21-17) }\end{array}$ & & 5 & \\
\hline $\mathrm{Sh}-3$ & & & 6.4 & & $\begin{array}{l}\text { Measured in lab at } 3000 \\
\text { psi compaction pressure }\end{array}$ \\
\hline $\operatorname{sh}-6$ & & & 12.1 & & $\begin{array}{l}\text { Measured in lab at } 6000 \\
\text { psi compaction pressure }\end{array}$ \\
\hline $\operatorname{sh}-9$ & & & 2.25 & & $\begin{array}{l}\text { Measured in lab at } 9000 \\
\text { psi compaction pressure }\end{array}$ \\
\hline
\end{tabular}


1. Birch, F.; Schairer, J. R., and Spicer, C. H., 1942, Handbook of Physical Constants: Geological Society of America, Special Paper No. 36, $325 \mathrm{p}$.

2. Emery, K. O., and Rittenberg, S. L., 1952, Early Diagenesis of California Basin Sediments in Relation to Origin of Oil: Am. Assoc. Pet.. Geol. Bull., v. 36, pp. 735-806.

3. Gondouin, M., and Scala, C., 1958, Streaming Potential and the SP Log: Trans.....M.E., v. 213, p. $170 \cdot 179$.

4. Johnson, A. I.; Moston, R.P., and Morris, D. A., 1968, Physical and ilydrologic Properties of Water Bearing Deposits in Subsiding Areas of Central California: United States Geol. Surv. Prof. Paper 497-A, Pp. 1-71.

5. Kharaka, Y. K. and Berry, F. A. F., 1973, Simultaneous Flow of Water and solutes through Geological Membranes - I. Experimental Investigation: Geochimica et Cosmochimica Acta. v. 37, pp. 2577-2603.

6. Maher, J. C.; Carter, R. D., and Iantz, R. J., 1975, Petroleum Geology of Naval Petroleurn Reserve No. 1, Elk Hills, Kern County, California: u. s. Geol. Surv. Prof. Paper 9l2, pp. $1-109$.

7. Manger, E. G., 1963, Porosity and Bulk Density of Sedimentary Rocks: U. S. Geol. Surv. BuII. 1144-E, $55 \mathrm{P}$.

B. Melcher, A. F., 1924, Texture of Oil Sands with Relations to the Production of Oil: Bull. Am. Assoc. Pet. Gr : v. 8, pp. 716-774.

9. Rilroad Comm ssio, of the state of -ilifornia and Department of Natural Resources, Estimate of the Natural Gas Reserves of the state of California as of January 1 , 1946: Case No. 4591, Spec. Study No. S-525.

1r. Regan, Jr., L. J., I953, Fractured shale Reservoirs of California: Bull. Am. Assoc. Pet. Geol.. v. 37, pp. 201-216. 
11. Regan, Jr., I. J. and Hughes, A. W., 1949, Fractured Reservoirs of Santa Marla Dlstrict, California: Bull. Am. Assoc. Pet. Geol., v. 33, Pp. 32-51.

12. Rieke, Herman H. III and Chilingarian, George V., 1974, Compaction of Argillaceous Sediments: Developments in Sedimentoloty, v. 16, $424 \mathrm{P}$.

13. Winograd, I. J.; Thomdarson, W., and Young, R. A., 19:1, Hydrology of the Nevada Test site and Vicinity, Southeastern Nevada: U. S. Geol. Surv. Open-File Report, 429 p. 
REGION 2: ROCKY MOUNTAINS AND COLORADO PLATEAU

The region occupied by the Rocky Mountains and the Colorado Plateau corresponds to the eastern edge of the North American Cordillera. The area is part of a craton which felt the commotions of the continuous tectonic activity along the shores of the Pacific. The two zones responded rather differently: the colorado Plateau by isostatic motion and the Rocky Mountains as an intracratonic folded mountain belt. During the Mesozoic, the Colorado Plateau became a landmass where thick continental units were piled up; while at the same time the Rocky Mountain was a zone of subsidence (e.g. the Denver Basin) where large accumulations of marine sediments were taking place. With the close of the Cretaceous and folding of the Rockies the whole region emerged and became a zone of deposition of continental shales rich in organic material (oil shales) (Eardley, 1962).

Three shale units can be distinguished:

-Triassic (Ankareh) and Jurassic (Morrison) shales are part of the continental sequence preserved in the colorado Plateau region.

-Cretaceous shales are of two types: continental in the Colorado Plateau (Thermopolis), they are marine in the Rocky Mountain basins and extend into adjacent regions. The most continuous of all is the Pierre shale (Fig. 8).

-Cenozoic shales are continental and belong to the oil shale group, they are Eocene in age (Green River Formation). 


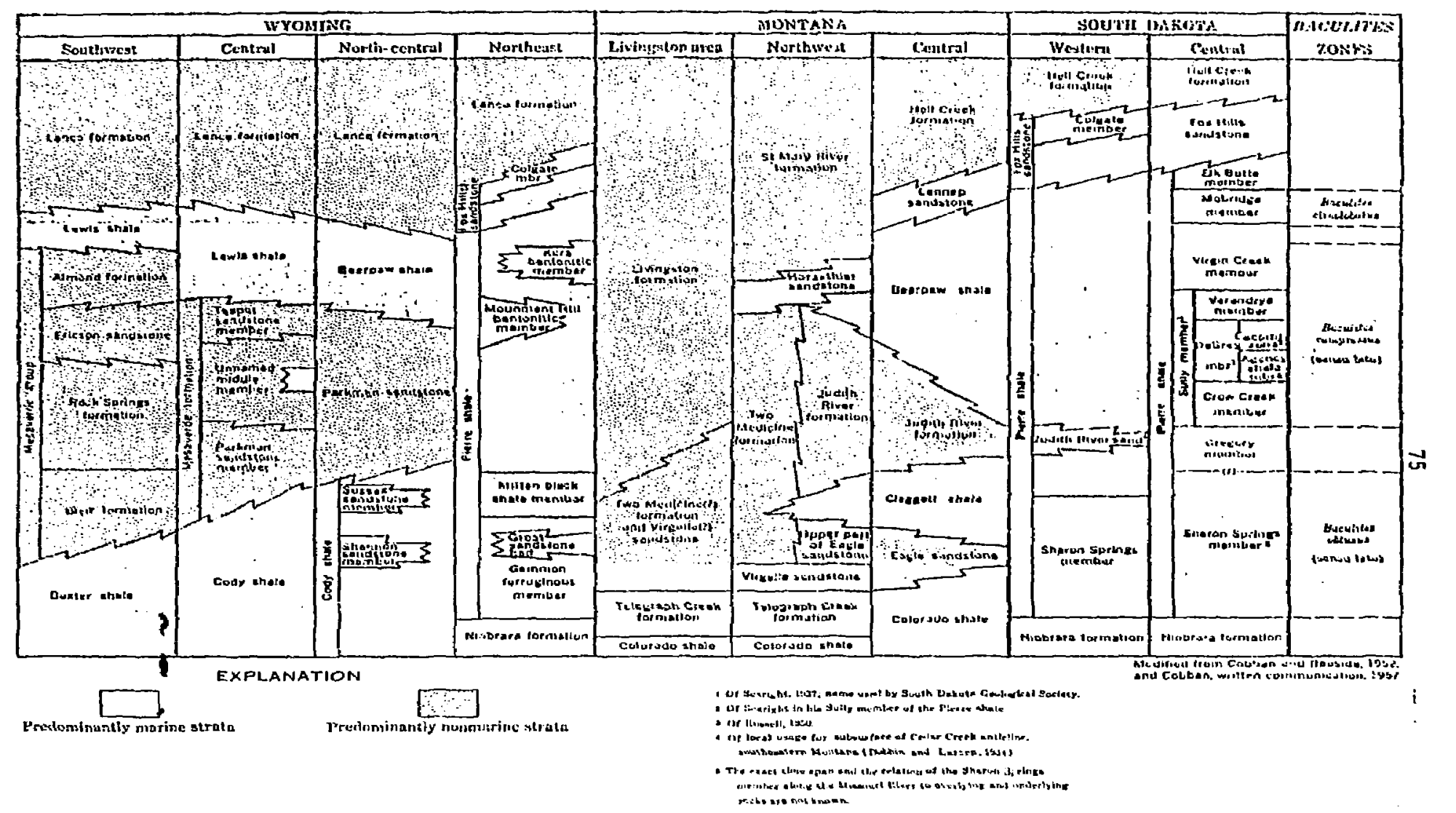

Figure 8: Stratigraphic relations of the pierre shale and equivalent rocks. (From Tourtelot, 1962) 
Structural relationships involving these units are illustrated in Figure 9. 


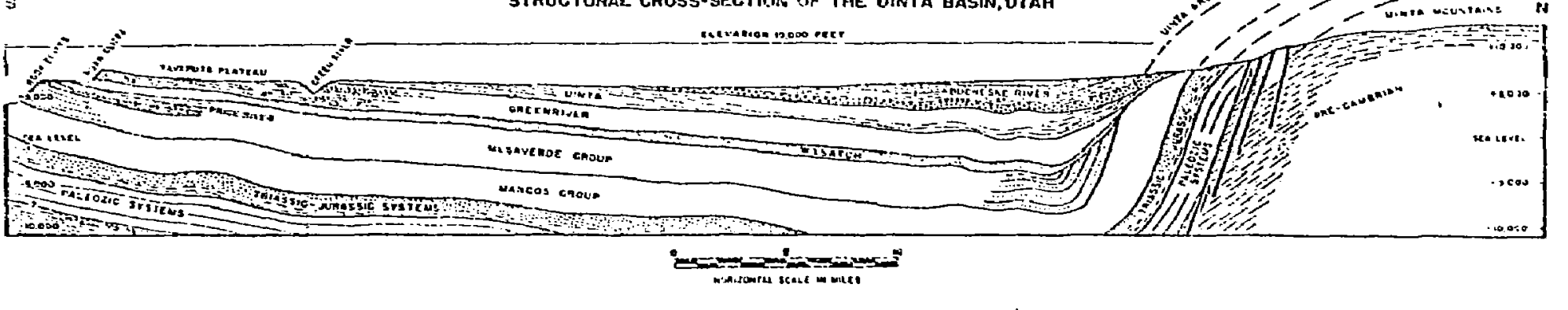

\section{5}

WIND RIVER DASIN

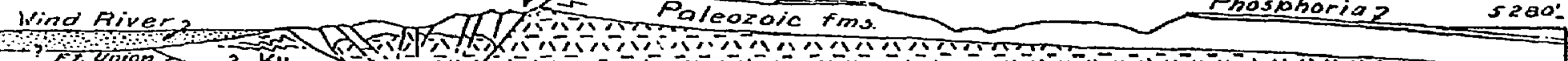

OVL CAEEN MOUNTAINS

M

Paleozaic rom DIGHORN GASIN

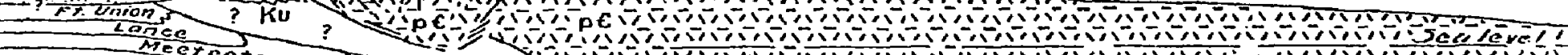

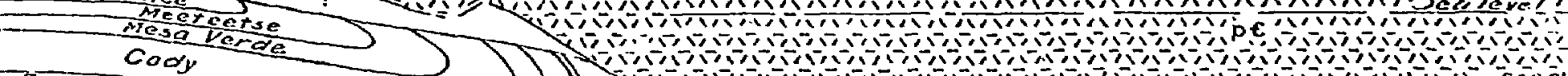

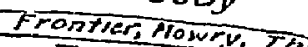

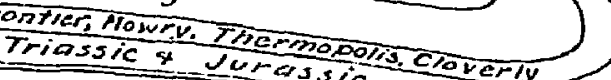

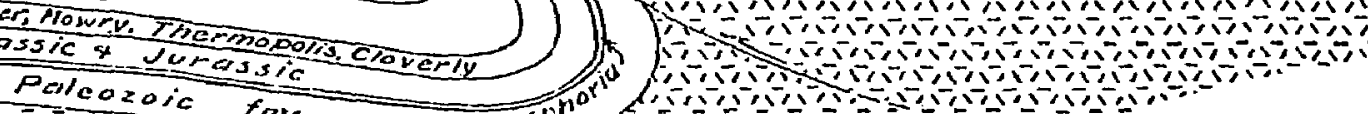

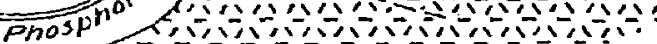

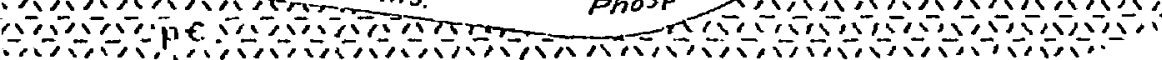

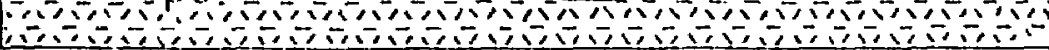

o

2

4

6 Miles

Figure 9: Structure sections showing typical relationships in the colorado

Plateau (top) and the Rocky Mountains (bottom). (After Earley, 1962) 
TABLE 4-2 SUMMARY OF ROCK UNI TS IN THE ROCKY MOUNTATNS; COLORADO PLATEAU AND GREAT PLATNS (From Gill et al. (1970) and Lee (1927)]

NOTE: Shales described in the hydrologic tables are preceded by *

\begin{tabular}{|c|c|c|c|c|}
\hline Age & & $\begin{array}{l}\text { Stratigraphic } \\
\text { Unit }\end{array}$ & $\begin{array}{l}\text { Thickness } \\
\text { (M) }\end{array}$ & Description \\
\hline PLIOCENE & & $\begin{array}{l}\text { Ogallala } \\
\text { Formation }\end{array}$ & $0-213$ & $\begin{array}{l}\text { Interbedded sand, siltstone, clay, lenses of } \\
\text { gravel, thin limestone, and caliche }\end{array}$ \\
\hline \multirow[t]{4}{*}{ EOCENE } & & Uinta Formation & 183 & Mudstones, sandstones, marlstones, and tuffs \\
\hline & & Briager Formation & 762 & Marlstones, mudstone, claystone, sandstones, tuffs \\
\hline & --- & $\begin{array}{l}\text { Green River } \\
\text { Formation }\end{array}$ & 976 & $\begin{array}{l}\text { Oil shale, mar1stone, minor sandstone and } \\
\text { limestone }\end{array}$ \\
\hline & & Wasatch Formation & & $\begin{array}{l}\text { Carbonaceous shale, sandstone, conglomerate, } \\
\text { lenticular coal beds }\end{array}$ \\
\hline $\begin{array}{l}\text { EOCENE TO } \\
\text { PAI_EOCENE }\end{array}$ & $\star$ & $\begin{array}{l}\text { Fort union } \\
\text { Formation }\end{array}$ & 1.220 & $\begin{array}{l}\text { Alternating shale and sandstone; basal } \\
\text { conglomerate }\end{array}$ \\
\hline $\begin{array}{l}\text { PALEOCENE TO } \\
\text { UPPER CRETRCEOUS }\end{array}$ & * & Lance Formaciun & 230 & $\begin{array}{l}\text { Alternating shale and sandstone; lenticular } \\
\text { sandstone beds }\end{array}$ \\
\hline
\end{tabular}


TABLE 4-2 (Continued)

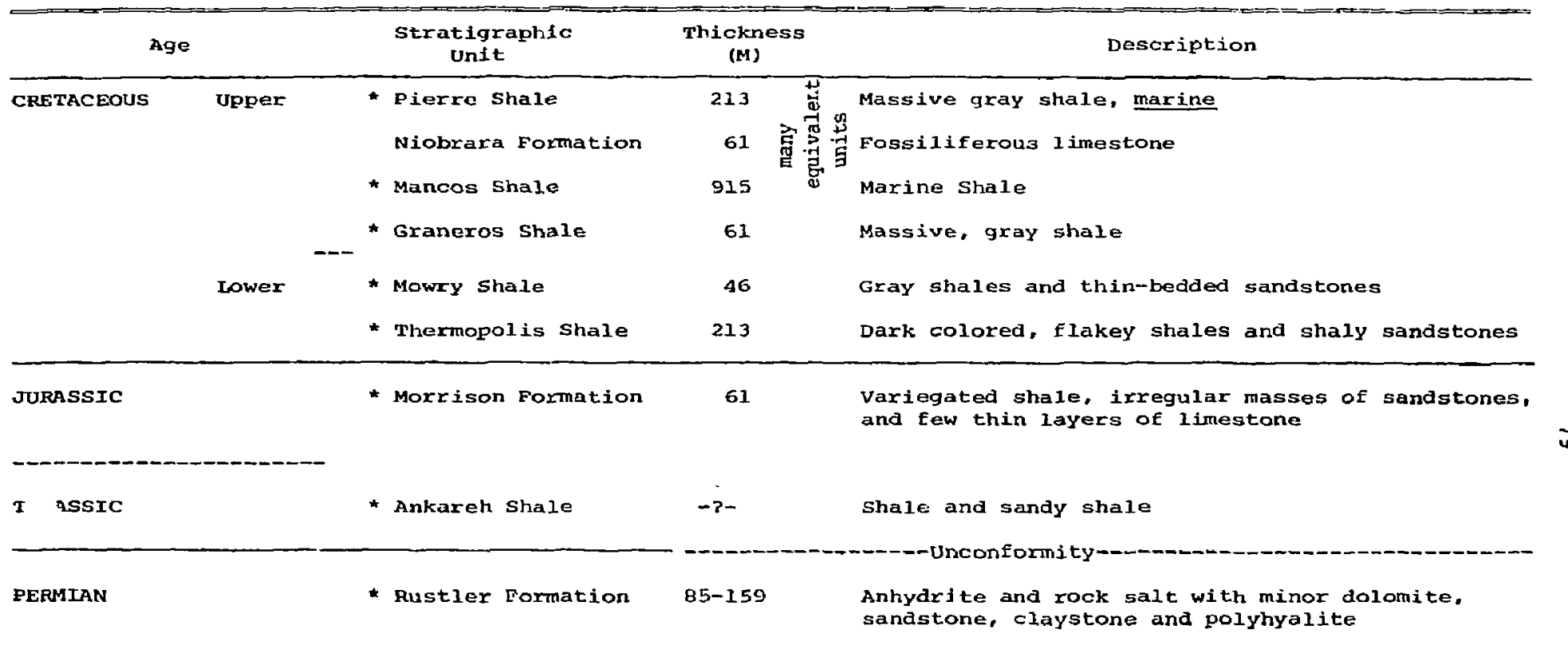




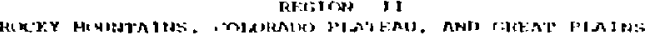

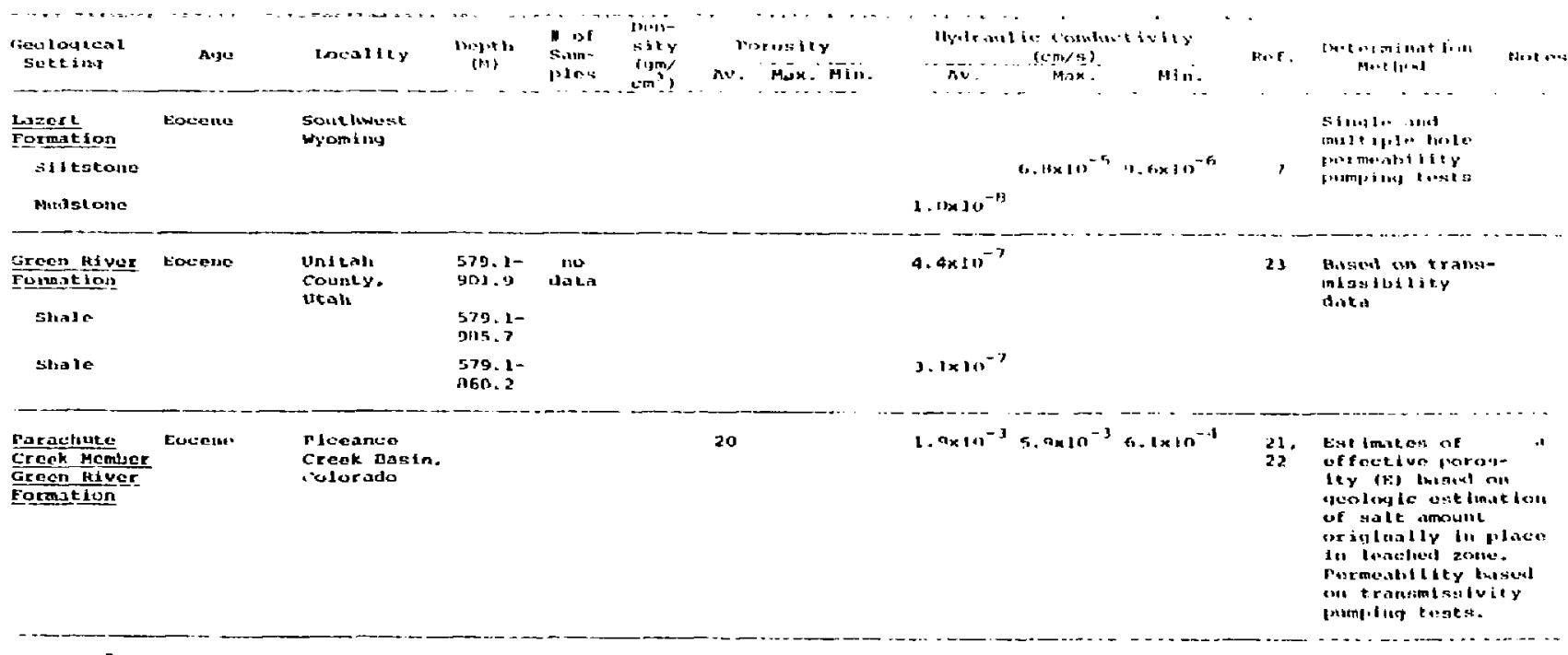

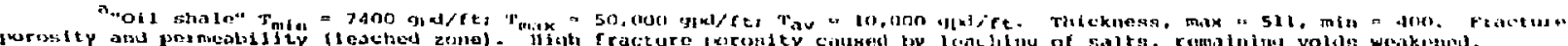




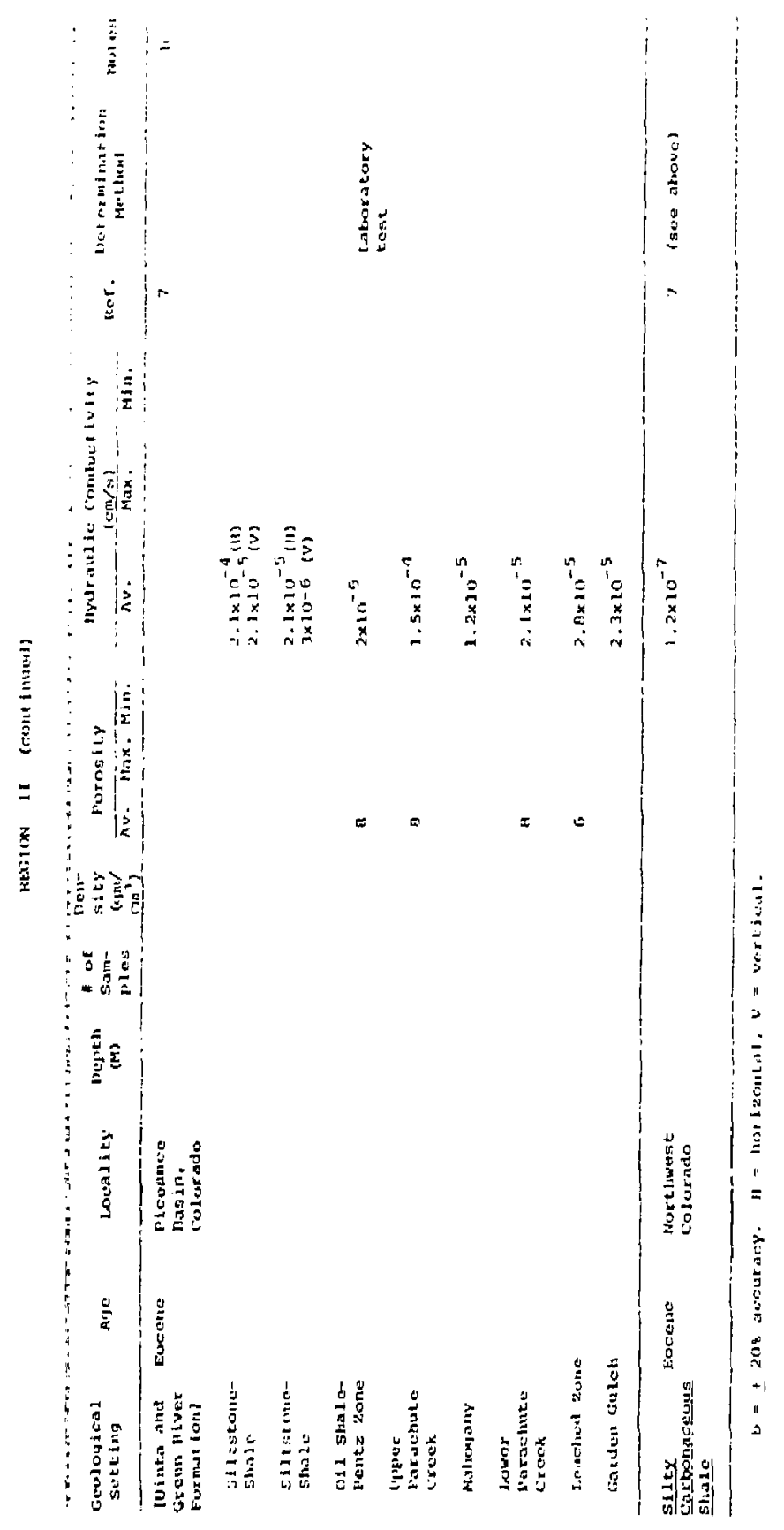


REGION $T$ (cont Inuor)

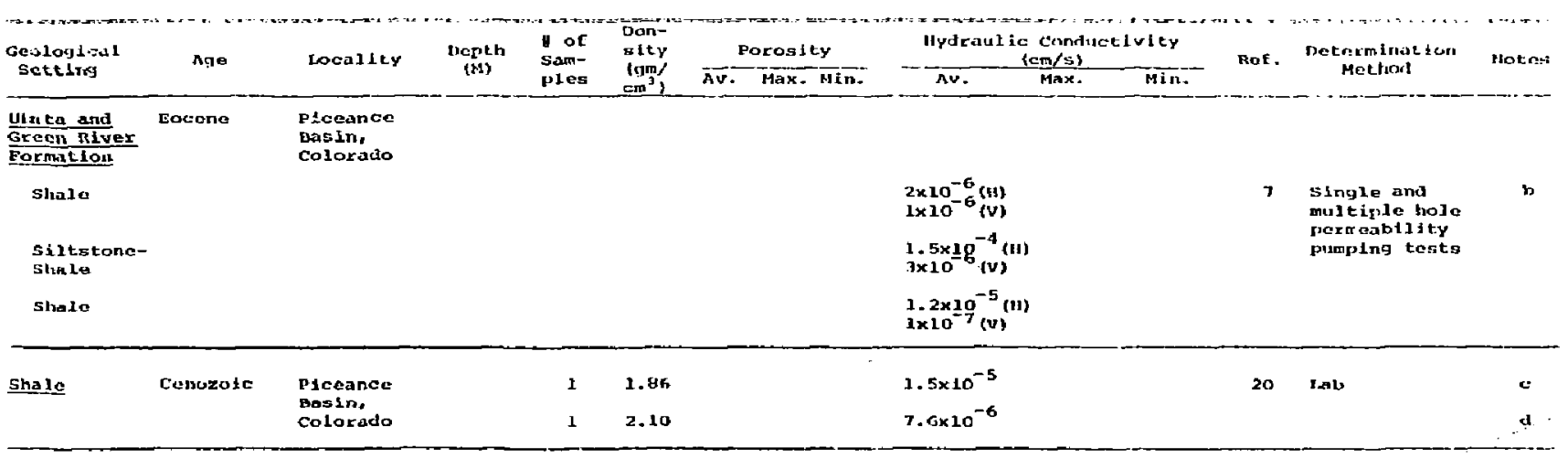

$b_{ \pm} 202$ accuracy. II = horlzontal, $v=$ vertical.

En situ. Room permablullty $1.3 \times 10^{-5} \mathrm{sm} / \mathrm{sec}$.

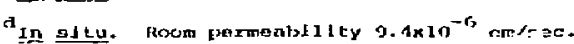




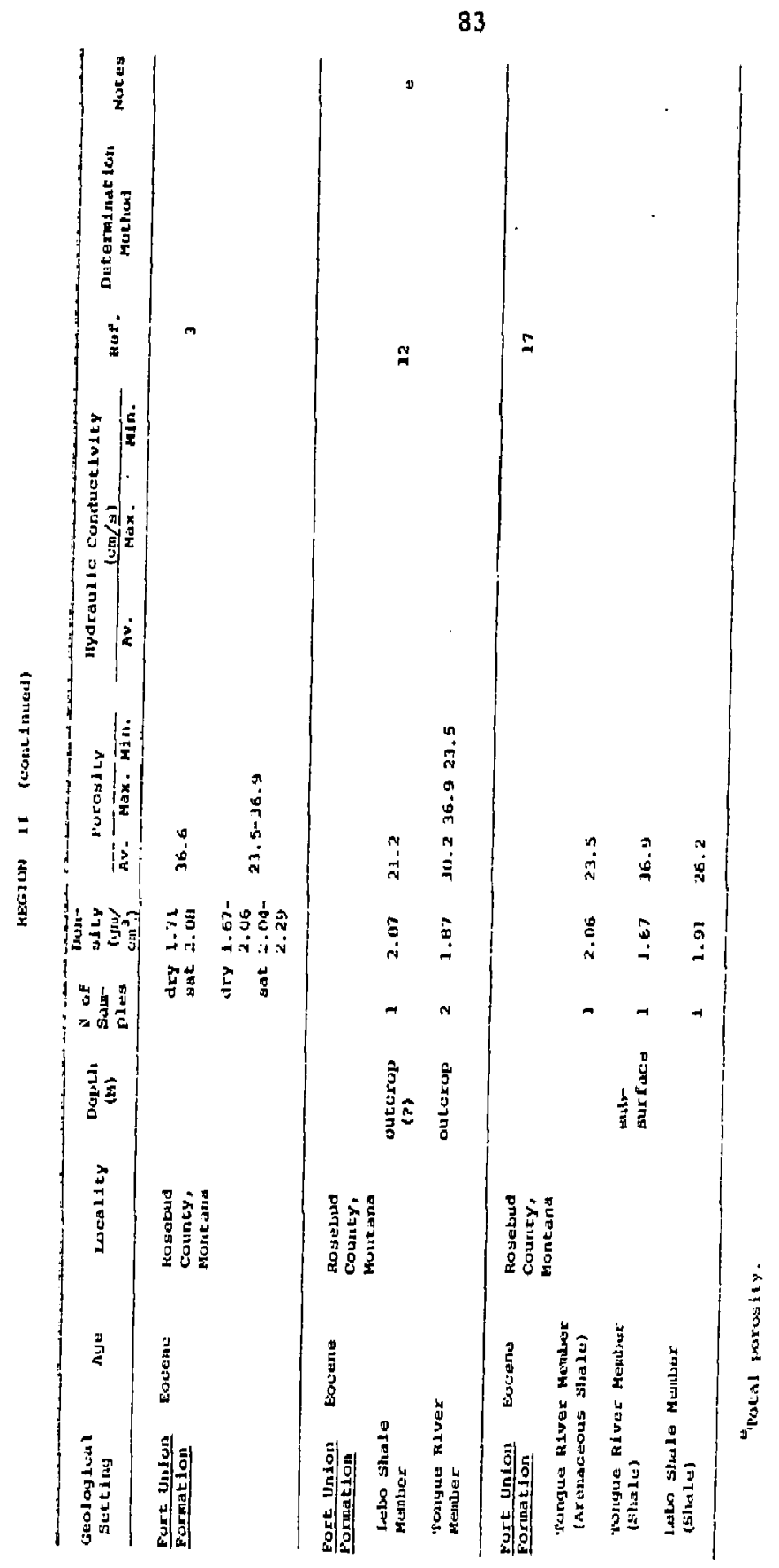


Fritilst 11 (cont imbed)

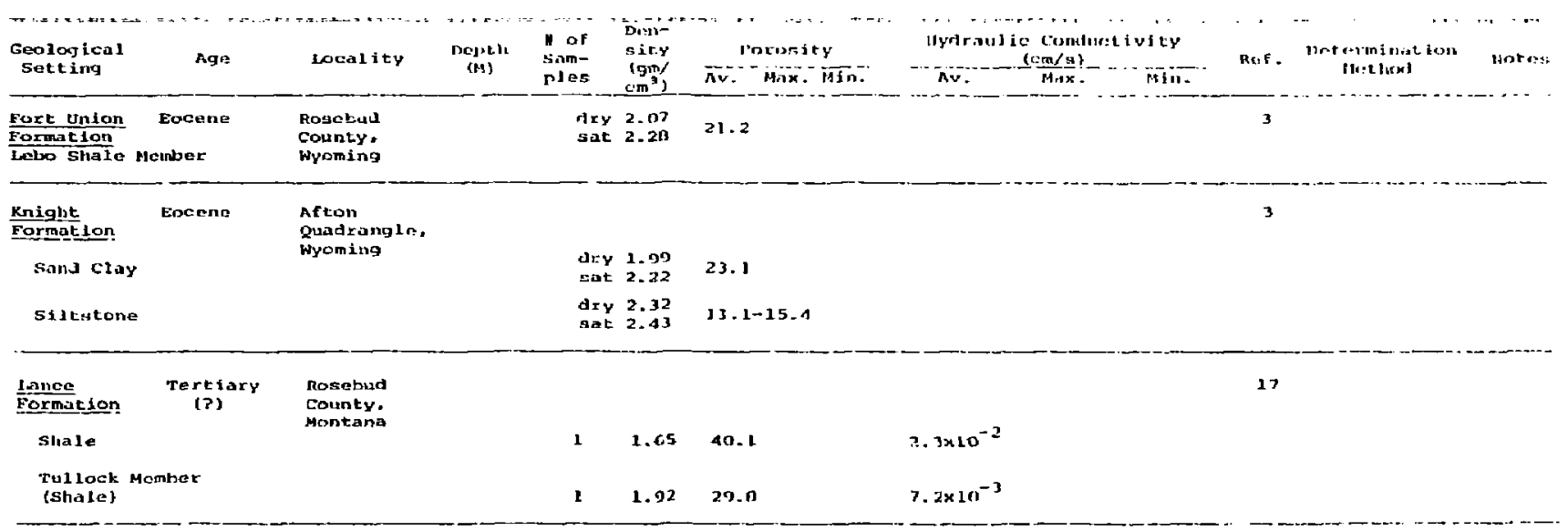




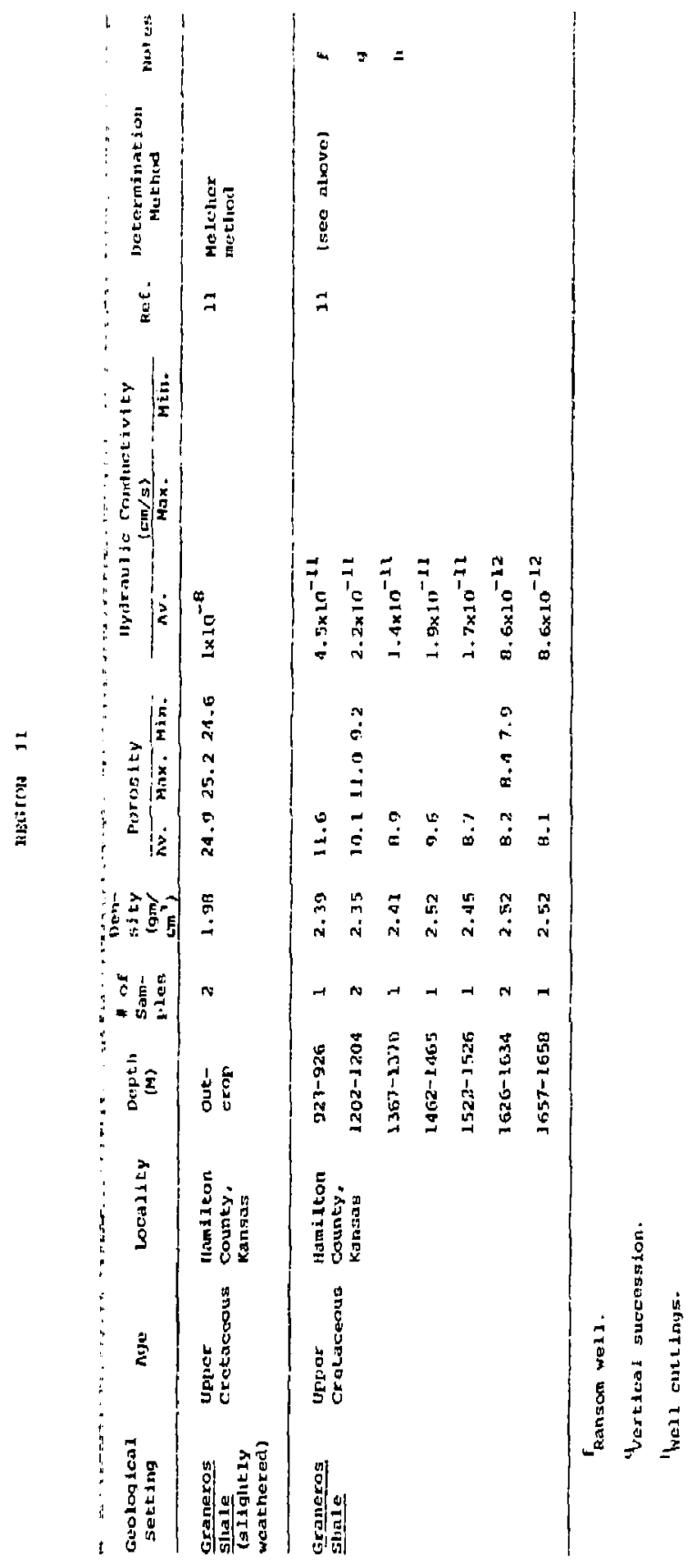




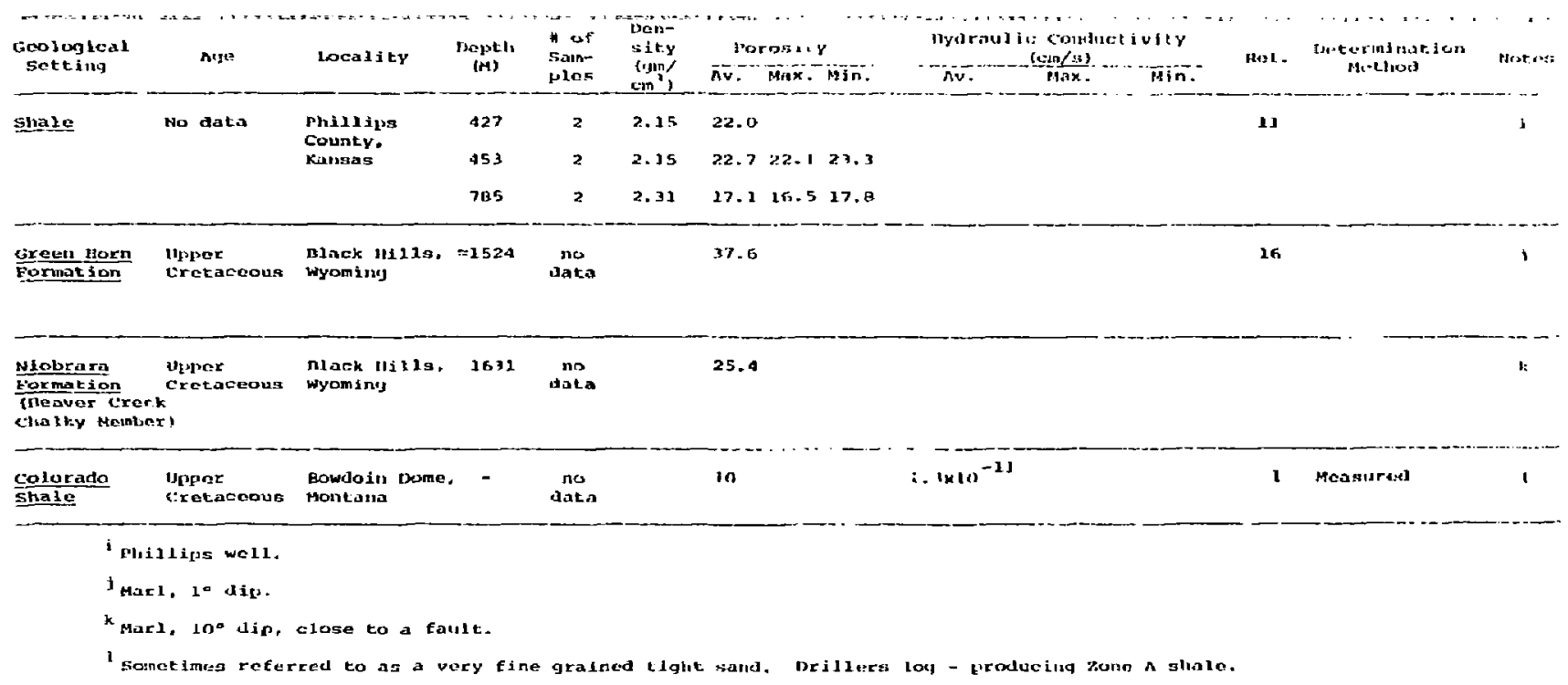




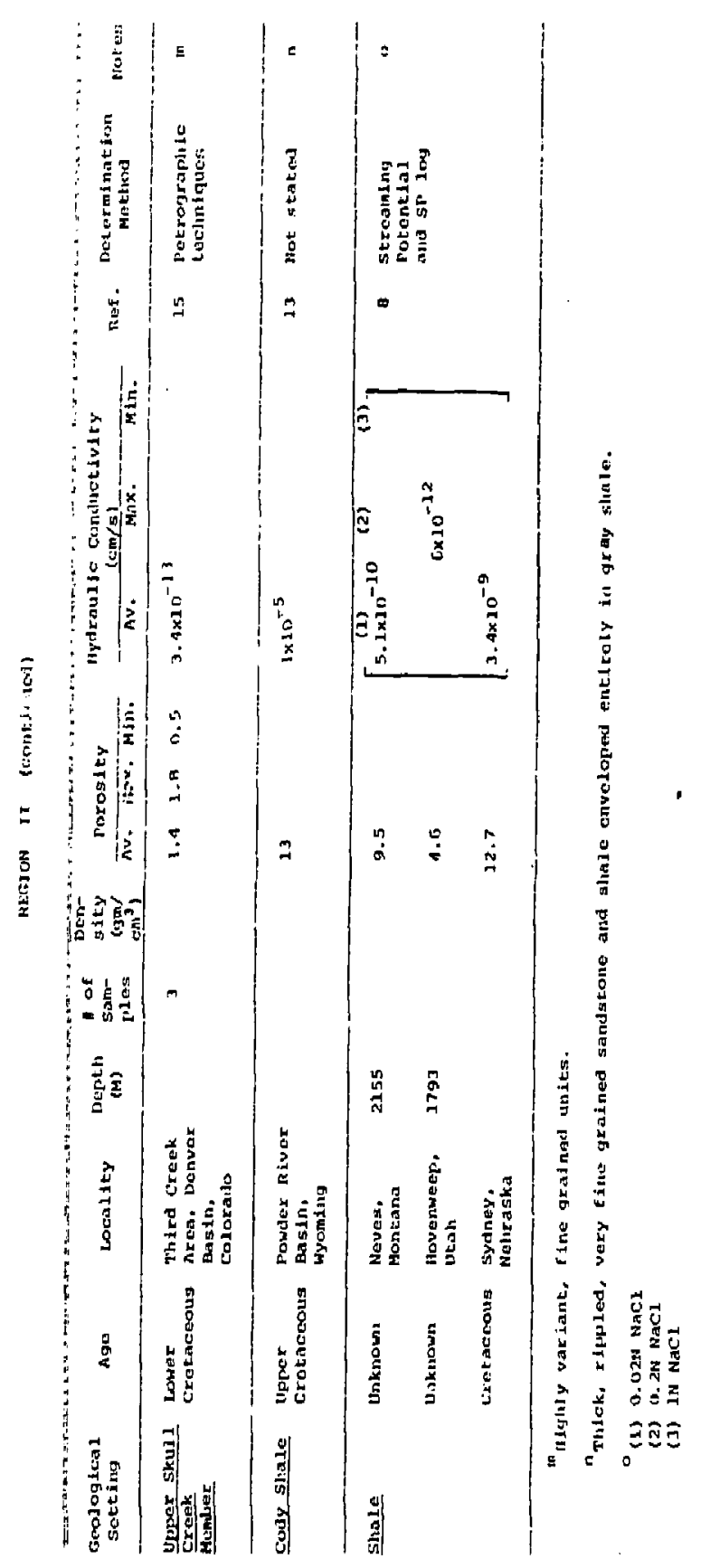


RERTION It tcontinuket)

\begin{tabular}{|c|c|c|c|c|c|c|c|c|c|c|c|c|}
\hline \multirow{2}{*}{$\begin{array}{l}\text { Goolonical } \\
\text { sete ing }\end{array}$} & \multirow[t]{2}{*}{ nge } & \multirow{2}{*}{ tocality } & \multirow{2}{*}{$\begin{array}{l}\text { Depth } \\
\text { (M) }\end{array}$} & \multirow{2}{*}{$\begin{array}{l}\text { of oE } \\
\text { Siun- } \\
\text { p1)=s }\end{array}$} & \multirow{2}{*}{$\begin{array}{l}\text { Den- } \\
\text { sitity } \\
\cos ^{2} y \\
\operatorname{cm}^{2} y\end{array}$} & \multicolumn{2}{|c|}{ pordosity } & \multicolumn{2}{|c|}{$\begin{array}{l}\text { Hydraul is: Conduclivity } \\
(\mathrm{cm} / \mathrm{s})\end{array}$} & \multirow{2}{*}{ nef. } & \multirow{2}{*}{$\begin{array}{l}\text { Boternination } \\
\text { Mcthoxd }\end{array}$} & \multirow{2}{*}{ Hentess } \\
\hline & & & & & & Av. & $\operatorname{Max} . \overline{1111}$ & Mux & Min- & & & \\
\hline Dentonite & 7 & Wyoming & & $\mathbf{L}$ & & 34 & & $4 \times 10^{-12}$ & $\cdot$ & 4 & Ints & " \\
\hline Slinte & 3 & New Hextoo & & & & & & $1.7 \times 10^{-12}$ & & 16 & Lialb & • 1 \\
\hline Slakilo & $?$ & $\begin{array}{l}\text { Fallon county } \\
\text { Montana }\end{array}$ & & $\begin{array}{l}\text { Ury } \\
\operatorname{sat}\end{array}$ & $\begin{array}{l}1.79 \\
2.013\end{array}$ & $28 . \mathrm{B}$ & & $1.4 \times 10^{-8}$ & & 1 & & \\
\hline \multirow[t]{3}{*}{ pontonitel } & 7 & Utalk & & & & & & $4.5 \times 10^{-13}$ & & 15 & 1ant. & 5 \\
\hline & & Wyomling & & & & 30 & & $3.4 \times 10^{-12}$ & & & & $\mathbf{s}$ \\
\hline & & Wroming & & & & 41 & & $1.3 \times 10^{-12}$ & & & & \\
\hline $\begin{array}{l}\text { Shale and } \\
\text { slitsione }\end{array}$ & Cretactous & $\begin{array}{l}\text { Iane, } \\
\text { twebraska }\end{array}$ & 1415 & & & & 7.02 .5 & $5.3 \times 10^{-12}$ & $5.3 \times 10^{-13}$ & 9 & $\begin{array}{l}\text { Gamma ray } \\
\text { attemmation }\end{array}$ & \\
\hline
\end{tabular}

$12.5 \mathrm{~N}$ Nacl solution as pemeal... Compaction load $2.75 \times 10^{10}$ dymes $/ \mathrm{cm}^{2}$.

4 o. 21 ilacl solution as permeant.

${ }^{x}$ sodiun-water perneant, 7 psi.

sa.000 l, 1 load. 


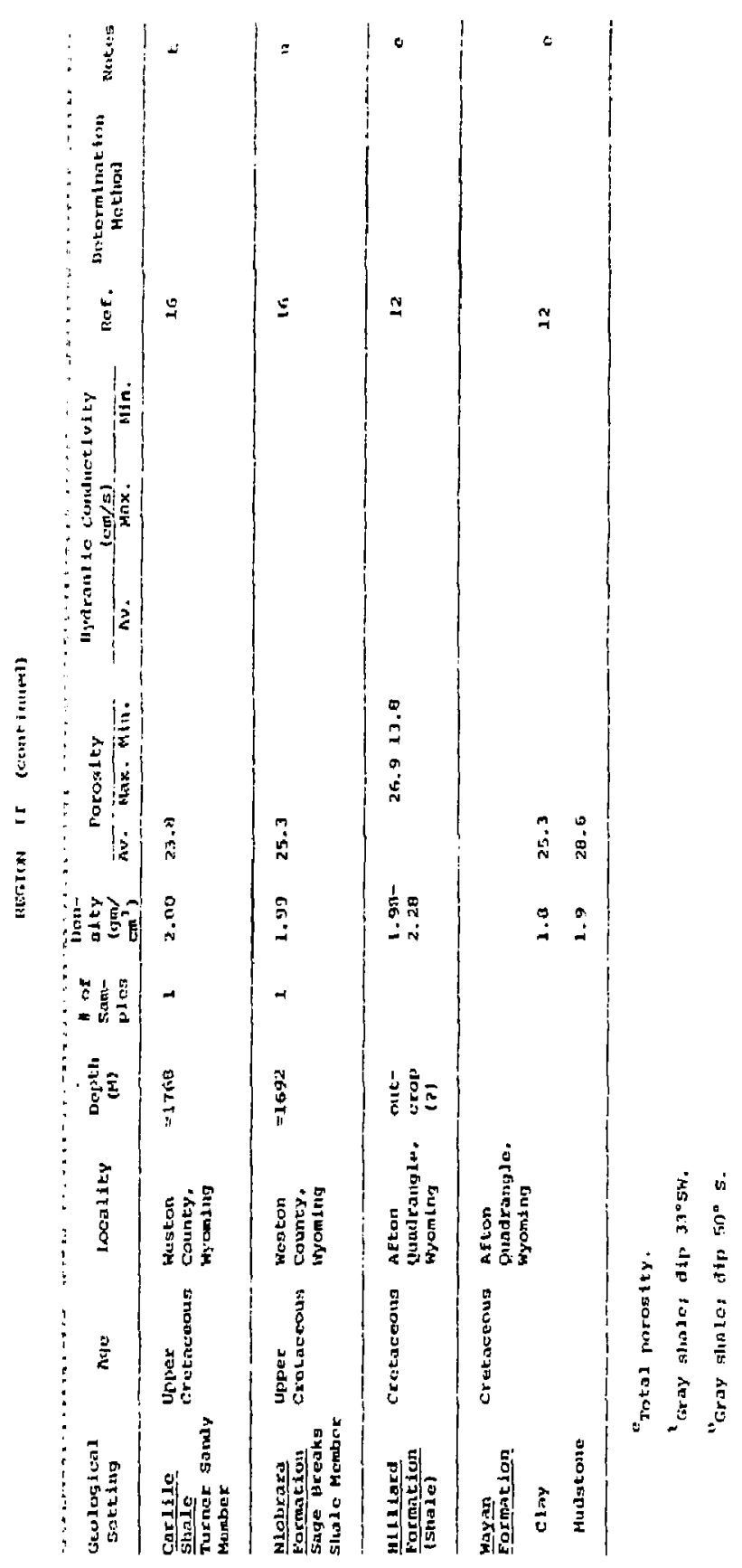




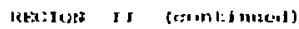

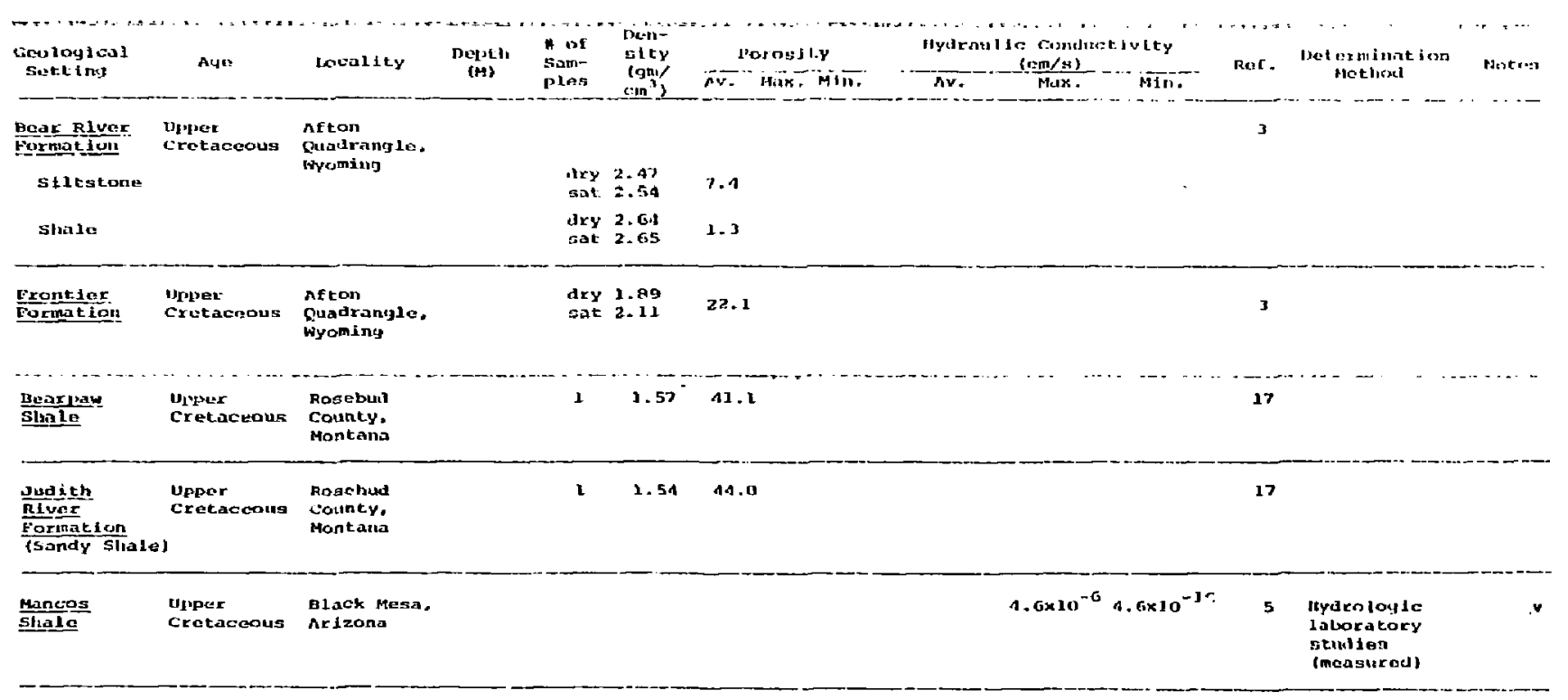

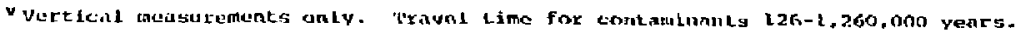


REgION IT (ContLinued)

\begin{tabular}{|c|c|c|c|c|c|c|c|c|c|c|c|c|c|}
\hline \multirow{2}{*}{$\begin{array}{l}\text { Geiployical } \\
\text { seteing }\end{array}$} & \multirow{2}{*}{ nigo } & \multirow{2}{*}{$\operatorname{lace} 11 \mathrm{ty}$} & \multirow{2}{*}{$\begin{array}{c}\text { Dept) } \\
\text { (M) }\end{array}$} & \multirow{2}{*}{$\begin{array}{l}\text { Dot } \\
\text { sann- } \\
\text { ples }\end{array}$} & \multirow{2}{*}{$\begin{array}{l}\text { alty } \\
\text { '9m, } \\
\text { cm? }\end{array}$} & \multicolumn{2}{|c|}{ Porostliy } & \multicolumn{3}{|c|}{$\begin{array}{l}\text { lydraude Confluct ivity } \\
(\mathrm{cm} / \mathrm{s})\end{array}$} & \multirow{2}{*}{ ner. } & \multirow{2}{*}{$\begin{array}{l}\text { neteriniane (an" } \\
\text { method }\end{array}$} & \multirow{2}{*}{ mates: } \\
\hline & & & & & & กิ. & max.Min: & Av. & Hix. & min- & & & \\
\hline$\frac{\text { Clagyot }}{\text { S1를 }}$ & $\begin{array}{l}\text { Upper } \\
\text { Cretanconus }\end{array}$ & $\begin{array}{l}\text { Roseburi } \\
\text { County. } \\
\text { Montania }\end{array}$ & & 1 & 1.81 & 36.3 & & & & & 17 & & \\
\hline cody sluale & $\begin{array}{l}\text { Uppor } \\
\text { Cretacious }\end{array}$ & $\begin{array}{l}\text { Geloo of } \\
\text { Field, llat } \\
\text { Springs } \\
\text { County. } \\
\text { Wyoming }\end{array}$ & $\begin{array}{l}220- \\
404\end{array}$ & & 2.53 & 9.1 & $|12.7 x| *$ & & & & 2 & & $\omega$ \\
\hline Mowry & $\begin{array}{l}\text { Lower } \\
\text { Cretacouns }\end{array}$ & $\begin{array}{l}\text { Gebo oil } \\
\text { Fieid, llot } \\
\text { springs } \\
\text { County. } \\
\text { Wroming }\end{array}$ & $\begin{array}{l}569- \\
678\end{array}$ & & 2.44 & 14.4 & $\{1.64\} *$ & & & & 2 & & $\boldsymbol{w}$ \\
\hline $\begin{array}{l}\text { Thanvoppol1s } \\
\text { jiliale }\end{array}$ & $\begin{array}{l}\text { Lowex } \\
\text { Cratricizuas }\end{array}$ & $\begin{array}{l}\text { Gebo oil } \\
\text { Field, llot } \\
\text { Springs }\end{array}$ & $\begin{array}{l}740- \\
781\end{array}$ & & 2.52 & 9.7 & {$[2.8 x]+$} & & & & 2 & & $\omega$ \\
\hline $\begin{array}{l}\text { Shel1 Critek } \\
\text { Mninber }\end{array}$ & & $\begin{array}{l}\text { County, } \\
\text { Hyorising }\end{array}$ & $\begin{array}{l}678- \\
73.3\end{array}$ & & 2.44 & 14.6 & {$[1.78]^{\circ}$} & & & & & & \\
\hline
\end{tabular}

"Poraslty and density calculatorl from burehole gravity survey.

porousity uneertainty. 


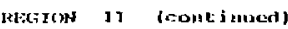

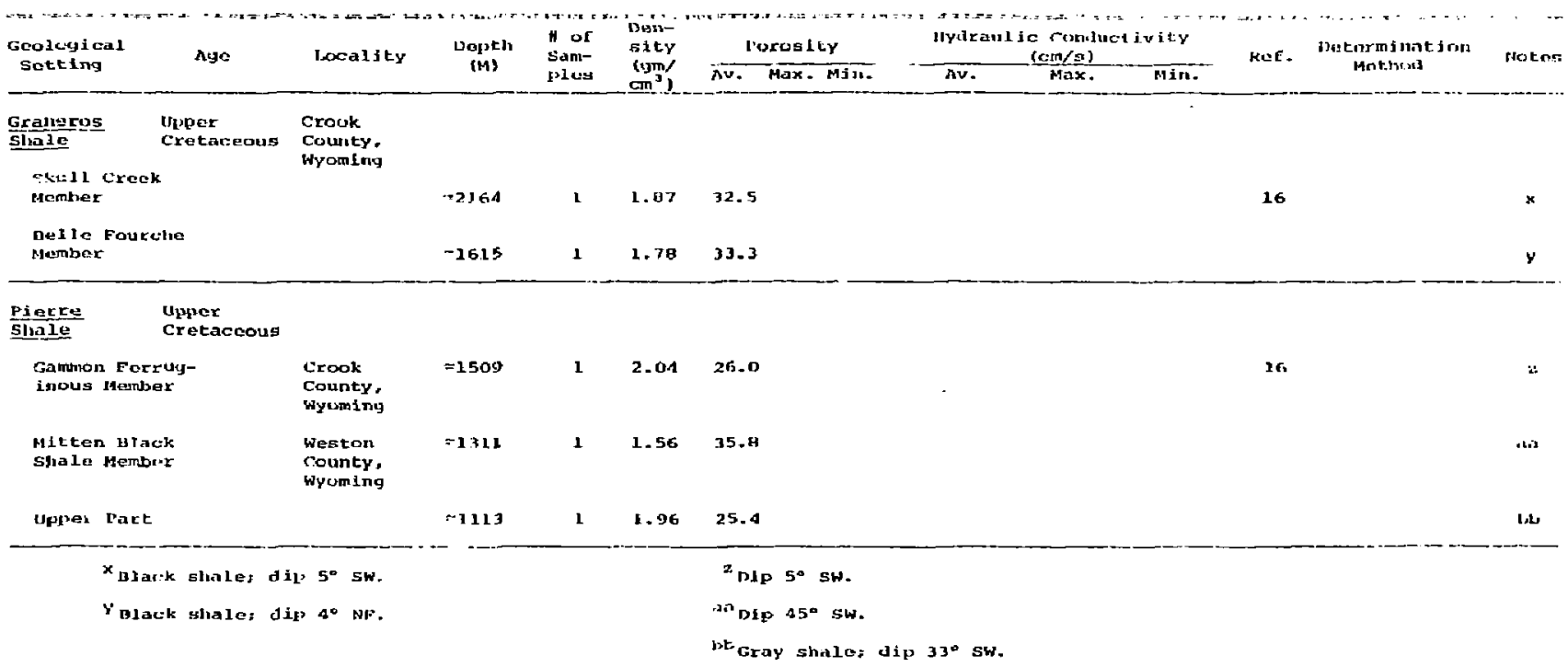

450 sw.

shalo: Jip $33^{\circ} \mathrm{sw}$ 
NE:GIUR II (contimmert)

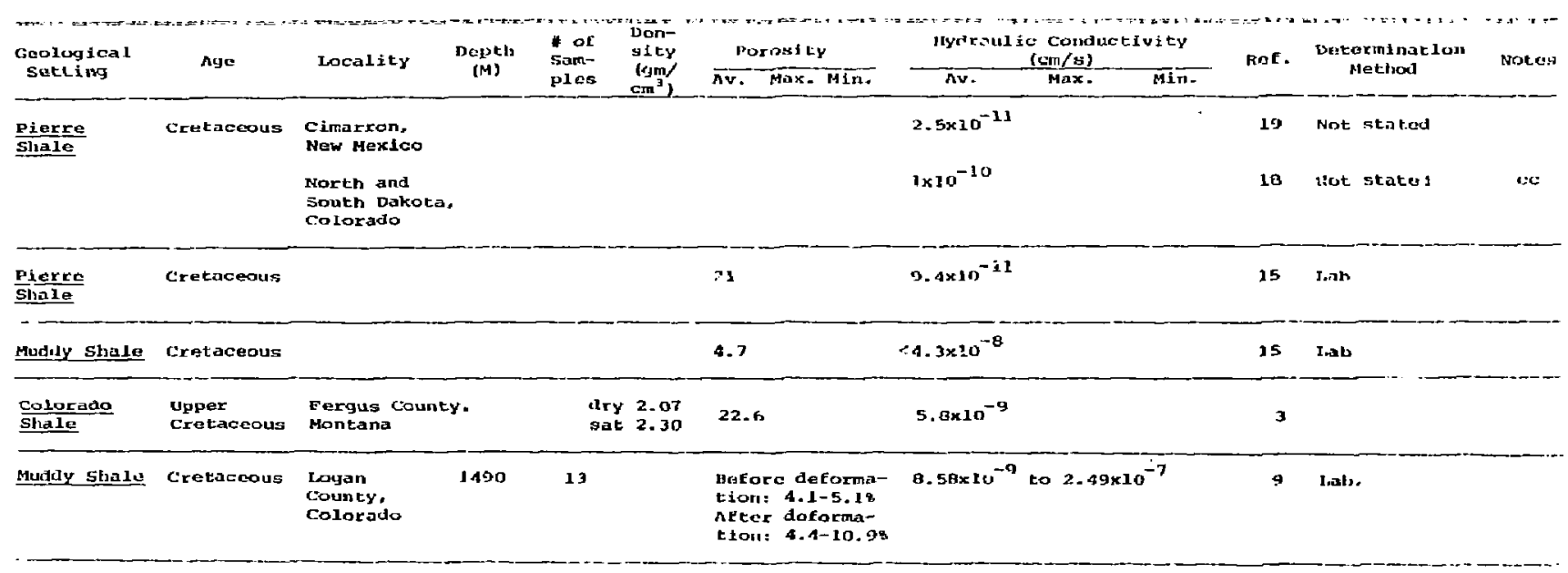

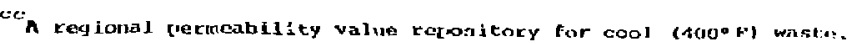


Heicilow II (Continmed)

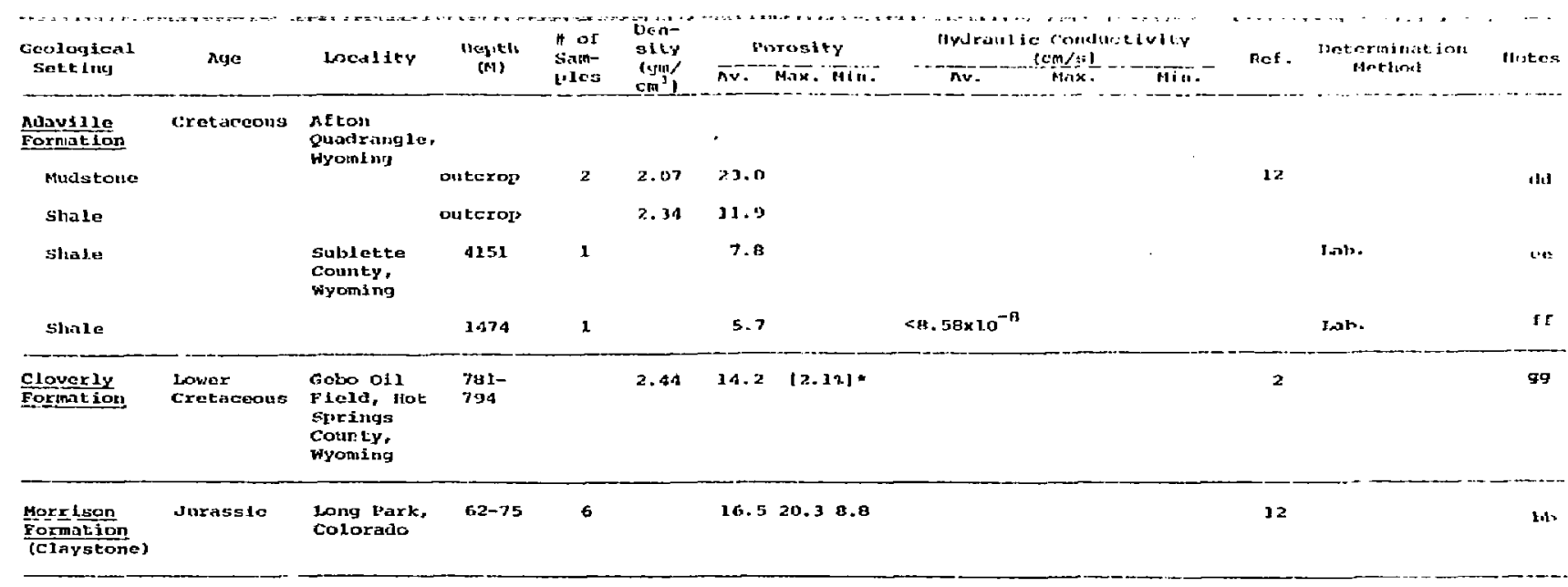

icalotal porosity.

Nowffectivis poranity.

git From borehole yravity suxvey. 


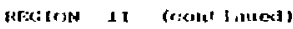

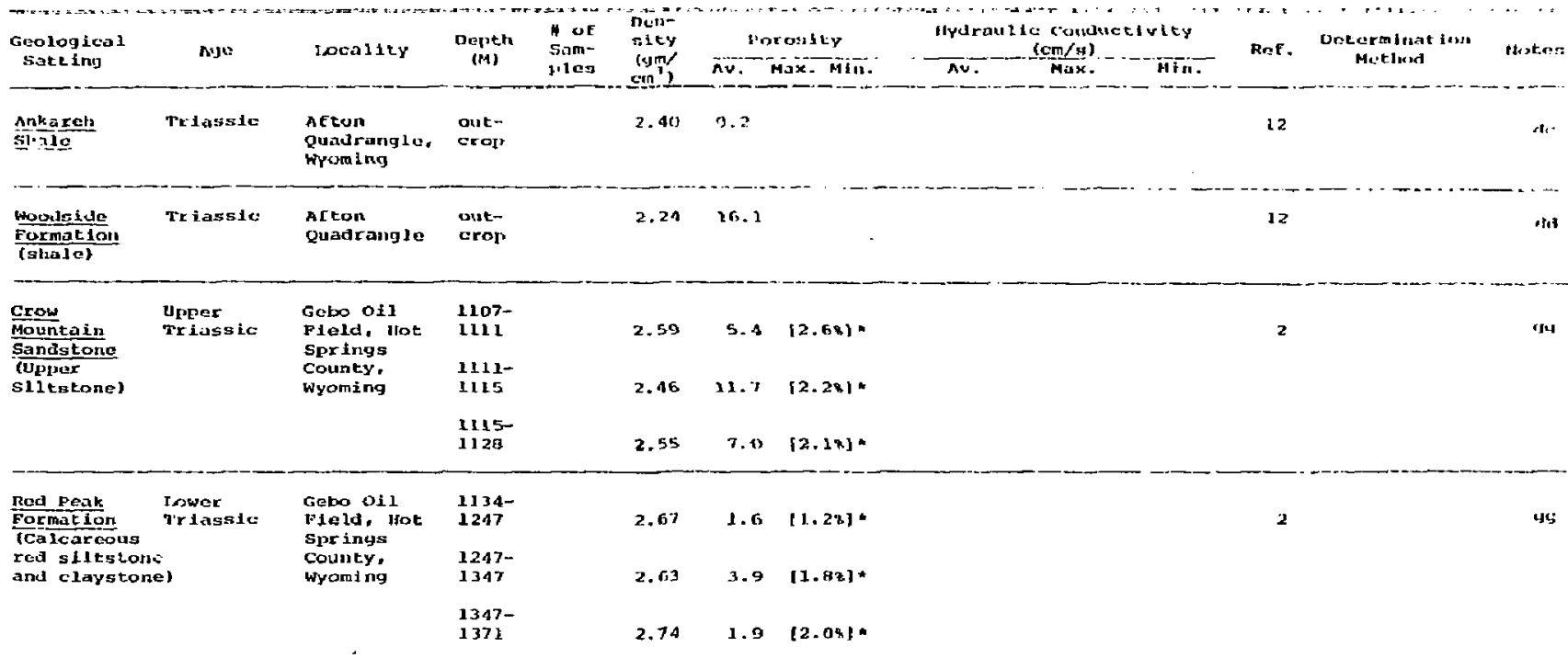

morosity uncertainty.

'dutul proxusity.

whroin toreliole gravity surver. 


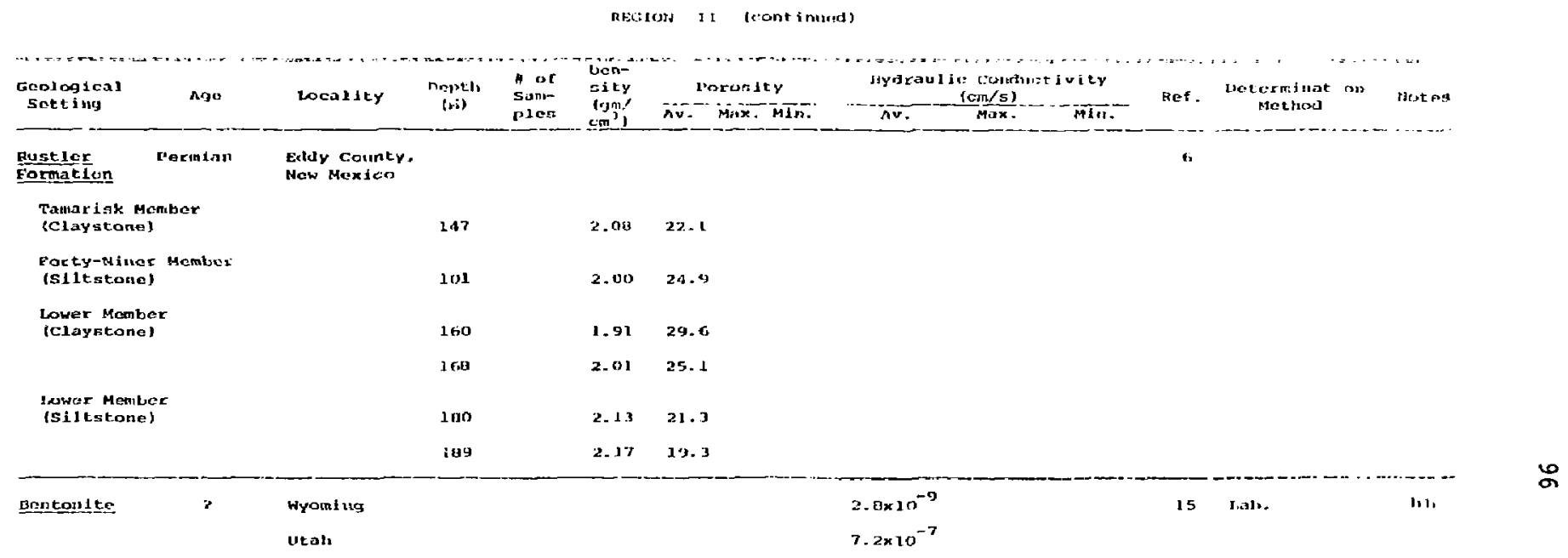

bhalelim-woter bolution useal as perineant ill 7 psi. 


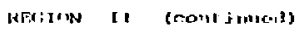

\begin{tabular}{|c|c|c|c|c|c|c|c|c|c|}
\hline $\begin{array}{l}\text { Guological } \\
\text { Setting }\end{array}$ & Ase & tocality & $\begin{array}{l}\text { poptht } \\
\text { (M) }\end{array}$ & $\begin{array}{l}\text { Dof } \\
\text { sama- } \\
\text { piess }\end{array}$ & 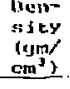 & $\begin{array}{l}\text { Doriseltey } \\
\text { Av. P1ax. Min. }\end{array}$ & 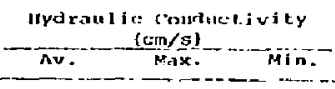 & Rrif. Deterininaticum & Hutess \\
\hline $\begin{array}{l}\text { Gros Yentere } \\
\text { Fonmerion }\end{array}$ & Cambrian & $\begin{array}{l}\text { neton } \\
\text { Quadrang } 18 . \\
\text { wyoning }\end{array}$ & $\begin{array}{l}\text { out- } \\
\text { cropp }\end{array}$ & & 2.38 & 11.1 & & 12 & it \\
\hline $\begin{array}{l}\text { Gylik } \\
\text { Eopmation }\end{array}$ & Canbrian & $\begin{array}{l}\text { Ophir, } \\
\text { Whith }\end{array}$ & & & & & & & \\
\hline Shale & & & suteurface & 1 & 2.81 & 0.9 & & 12 & 3 \\
\hline $\begin{array}{l}\text { Shliedfied } \\
\text { shale }\end{array}$ & & & nubsurfacto & 1 & 2.0 & 0.6 & & & \\
\hline
\end{tabular}


REGION II

OTHER PROPERTIES

\begin{tabular}{|c|c|c|c|c|c|c|c|c|}
\hline Formation & Age & Locality & $\begin{array}{l}\text { Depth } \\
\text { (M) }\end{array}$ & $\begin{array}{l}\text { No. of } \\
\text { Samples }\end{array}$ & $\begin{array}{l}\text { Compressive } \\
\text { strength } \\
\text { (1bs/in2) }\end{array}$ & $\begin{array}{l}\text { Ultimate } \\
\text { strength } \\
\text { (bars) }\end{array}$ & $\begin{array}{l}\text { Resistivity } \\
\left.\text { (otm } M^{2} / M\right)\end{array}$ & Ref. \\
\hline$\frac{\frac{\text { Ophix }}{\text { Formation }}}{\text { (Shale) }}$ & Cambrian & Ophix, vtah & $\begin{array}{l}\text { Sub- } \\
\text { surface }\end{array}$ & 2 & 31,300 & & & 12 \\
\hline (Silicified & Shale) & & $\begin{array}{l}\text { Sub- } \\
\text { surface }\end{array}$ & 1 & 33.500 & & & \\
\hline $\begin{array}{l}\text { Muady } \\
\text { Shale }\end{array}$ & Cretaceous & $\begin{array}{l}\text { Logan County, } \\
\text { Colorado }\end{array}$ & 1490 & 13 & & $400-4170$ & & 9 \\
\hline Cody Shale & $\begin{array}{l}\text { Upper } \\
\text { Cretaceous }\end{array}$ & $\begin{array}{l}\text { isibo oil } \\
\text { Field, Hot } \\
\text { springs County, } \\
\text { Wyoming }\end{array}$ & $\begin{array}{l}220 \\
404\end{array}$ & & & & $\begin{array}{ll}\text { Range: } & 4-9 \\
\text { Ave: } & 5\end{array}$ & 2 \\
\hline$\frac{\text { Mowry }}{\text { Shale }}$ & $\begin{array}{l}\text { Lower } \\
\text { Cretaceous }\end{array}$ & $\begin{array}{l}\text { GeDo Oil } \\
\text { Field, Hot } \\
\text { Springs County, } \\
\text { Wyoming }\end{array}$ & $\begin{array}{l}569- \\
678\end{array}$ & & & & $\begin{array}{l}\text { Range: } 3-22 \\
\text { Ave: } 8\end{array}$ & 2 \\
\hline $\begin{array}{l}\text { Thermopolis } \\
\text { Shale. } \\
\text { Shell Creek } \\
\text { Member }\end{array}$ & $\begin{array}{l}\text { Lower } \\
\text { Cretaceous }\end{array}$ & $\begin{array}{l}\text { Gebo oll } \\
\text { rield, Hot } \\
\text { Springs county, } \\
\text { Wyoning }\end{array}$ & $\begin{array}{l}678 \\
733\end{array}$ & & & & $\begin{array}{ll}\text { Range: } & 2-6 \\
\text { Ave: } & 4\end{array}$ & 2 \\
\hline
\end{tabular}


FEGION II: OTHER PROPERTIES (continued)

\begin{tabular}{|c|c|c|c|c|c|c|c|c|c|}
\hline Formation & Age & Iocality & $\begin{array}{l}\text { Depth } \\
\text { (M) }\end{array}$ & $\begin{array}{l}\text { No. of } \\
\text { Samples }\end{array}$ & $\begin{array}{l}\text { Compressive } \\
\text { Strength } \\
\text { (1bs/in2) }\end{array}$ & $\begin{array}{l}\text { Ultimate } \\
\text { Strength } \\
\text { (bars) }\end{array}$ & $\begin{array}{l}\text { Resisty } \\
\text { (ohm } \mathrm{M}^{2}\end{array}$ & ivity & Ref. \\
\hline $\begin{array}{l}\text { Thermopolig } \\
\text { Shale }\end{array}$ & $\begin{array}{l}\text { Lower } \\
\text { Cretaceous }\end{array}$ & $\begin{array}{l}\text { Gebo ofl } \\
\text { Field, Hot } \\
\text { Springs County, } \\
\text { Wyoming }\end{array}$ & $\begin{array}{l}740- \\
794\end{array}$ & & & & $\begin{array}{l}\text { Range: } \\
\text { Ave: }\end{array}$ & $\begin{array}{l}3-14 \\
5\end{array}$ & 2 \\
\hline $\begin{array}{l}\text { cloveriy } \\
\text { Formation }\end{array}$ & $\begin{array}{l}\text { Lower } \\
\text { Cretaceous }\end{array}$ & $\begin{array}{l}\text { Gebo oil } \\
\text { Field, Hot } \\
\text { Springs County, } \\
\text { Wyoming }\end{array}$ & $\begin{array}{l}781- \\
794\end{array}$ & & & & $\begin{array}{l}\text { Range: } \\
\text { Ave: }\end{array}$ & $\begin{array}{l}3-6 \\
4\end{array}$ & 2 \\
\hline $\begin{array}{l}\frac{\text { Crow }}{\text { Mountain }} \\
\text { Sandstone- } \\
\text { Upper } \\
\text { Siltstone }\end{array}$ & $\begin{array}{l}\text { Upper } \\
\text { Triassic }\end{array}$ & $\begin{array}{l}\text { Gebo oil } \\
\text { Field, Hot } \\
\text { Springs County, } \\
\text { Wyoming }\end{array}$ & $\begin{array}{l}1107- \\
1112 \\
1111- \\
1125\end{array}$ & & & & $\begin{array}{l}\text { Range: } \\
\text { Ave: } \\
\text { Range: } \\
\text { Ave: }\end{array}$ & $\begin{array}{l}20-25 \\
23 \\
19-30 \\
25\end{array}$ & 3 \\
\hline & & & $\begin{array}{l}1115- \\
1128\end{array}$ & & & & $\begin{array}{l}\text { Range: } \\
\text { Ave: }\end{array}$ & $\begin{array}{l}30-36 \\
33\end{array}$ & \\
\hline$\frac{\text { Moencopie }}{\text { Shale }}$ & & $\begin{array}{l}\text { Neteor Crater, } \\
\text { Arizona }\end{array}$ & & & & & $2 \times 10^{-4}$ & ohm-om & 3 \\
\hline
\end{tabular}


1. Bartram, I. G., and Erdmann, C. E., 1935, Natural Gas In Montana, in Ley, H. 7.. (ed.), Geology of Natural Gas: Amer. Assoc. Pet. Geol.. Tulsa, pp. 245-276.

2. Beyer, L. A. and Clutsom, F. G., 1978, Density and Porosity of oil Reservoirs and Overlying Formations from Borehole Gravity Measurements, Gebo Oil Field, Hot Spririgs County. Wyoming : Oil and Gas Investigations, U. S. Geological Survey, Chart oc-88.

3. Birch, F.: Schairer, J. R., and Spicer, C. H, 1942, Handbook of Physical Constants: Geological Society of America, Sprcial Paper No. 36, $325 \mathrm{p}$.

4. Bredehoeft, J. D. and Hanshaw, B. B., 1968, On the Maintenance of Anomalous Fluid Preaaures I. Thick Sedimentary sequences: Geological Society of America Bulletin, v. 79, no. 9. PP. 1097-1106.

5. Dove, A. H. and Roefs, T. G., 1973, Competitive Groundwater Usage from the Navajo Sandstone: Hydxo1. Water Resources Ariz. Southwest, v. 3, p. 124-135.

6. Gard, L. M. Jr., 1968, Geologic studies, Project Gnome, Eddy County, New Mexico: U. S. Geol. Survey Professional iaper 589.

7. Golder Associates, 1977, Second study, Development of site suitability Criteria for a High Level Waste Repository: A Report to Lawrence Livermore Laboratory, UCFI-13793, 440 p.

8. Gondouin, M., and Scala, C., 1958, Streaming Potential and the SP Iog: Trans. A.I.M.E., v. 213, P. $170-179$.

9. Handin, J.; Hager, R. V.. Jr.; Friedman, M., and Feather, J. N., 1963, Experimental Deformation of Sedimentary Rocks Under Confining Pressure: Pore Pressure Tests: American Association of Petroleum Geologists Bulletin, v. 47, no. 5, pp. 717-755.

10. Harms, J. C., 1966, stratigraphic Traps in a ValleY Fill, Western Nebraska: Ayn. Assoc. Pet. Geol. Bull., v. So, p. 2119-2149. 
REGION II = REFERENCES (continued)

11. Hedterg, H. D., 1926. The Effect of Gravitational compaction on the structure of Sedimentary Rocks: Bull. Am. Assoc. Pet. Geol., v. I0, pp. 1035-1072.

12. Manger, B. G.. 1963, Porosity and Bulk Density of seaimentary Rocks: U. 5. Geclogical Survex Bulletin 1244-E, $55 \mathrm{p}$.

13. Martinsen, R. S., and Tilimal, R. W., 1978, Hartzog Draw, New Giant oil Field: Amer. Assoc. Pet. Geol. Bull., v. 62, p. 540 .

14. Reinert, S. I., and Davies, D. K., 1976. Third Creel Field, Colorado: A study of Sandstone Environments and Diajoncsis: Mountain Geol., v. 13, Pp. 47-60.

15. Rieke, Herman H. III, and Chilingarion, George V., 2974, Compaction of Argillaceous Sediments: Developments in sedimentology, v. 16, 424 p.

16. Rubey, W. .... 1930, Lithologic Studies of Fine-Grained Upper Cretaceous Sedimentary Rocks of the Black tills Region: U. S. Geol. Surv., Prof. Paper I65-A. pp. 1-54.

17. Stearns, N. D., 1927, Laboratory Tests on Physical Properties of water-Bearing Hateriałs: U. S. Geological Survey water supply Faper 596, pp. 121-176.

18. Shuxp, G. W., and Bredehogdal, J. D., 1977, The Pierxe shale as a Possible Wastis Repository Abstr: Geol. Soc. Amer. Abstr. Programs, v. 9, no. 7, P, 1174.

19. Summers, W. K.; Balgstrom, R, E.; Walker, C. W., ana Hammock, G., 1977, Hyaxogeclogic Investigation for Low-Level Radwaste Disposal Near Cimarxon, New Mexico: Geol. Soc. Amer. Abstr. Programs, v. 9, no. 7, p. 1193-1194.

20. Thomas, C. W.. 1966, Some Effects of Overburdin Pressure on Oil shale During Underground Retorting: Society of Petroleum Engineers Journal, v. 6, no. 1, pp. 1-8.

21. Weichman, B. E., 1974, Some Effects of the Rlo Blanco Nuclear Detonation on the Leached Zone in the Parachute Creek Member of the Green Hiver Formation: Rocky Mt. Assoc. Geol. Field Conf. Guide, no. 25, Guidebook to the Energy Resources of the Piceance Creek Basin, Colorado, P. 205-215. 
REGION II : REFERENCES (continued)

22. Weichman, B. E., 1975, Depositional History and Hydrology of the Green River O.t Shale, Piceance Creek Basin, Rio Blanco County, Colorado: A.I.M.E. Trans, V. 256, P. 272-277.

23. Weir, J. E., 1970, Geohydrology of the Area Near Wosco, Exploxatory Hole Number: 1, Unitah County, Utah, U. S. Geol. Surv. gpen-File Report, 27 p. 
REGION 3: THE MIL CONTINENT

The Mid Continent region is broadly spread between the Rocky Mountains and the ippalachians and the Canadian Shield and the Gulf coast. It is a craton which underwent some deformation at the end of the Paleozoic in its southern fortion (Eardley, 1962) forming numerous domes and basins (Fig.10). This is the common setting for the Chattanooga Shaie (Fig. 11). During the Mesozoic the region was invaded by epicontinental seas where extensions of Rocky Mountain units (e.g. equivalents of the Pierre shale) were deposited.

Examples of the simple structural relationships characterizing the Mid Continent are shown in Fig. 12 . 


\section{4}

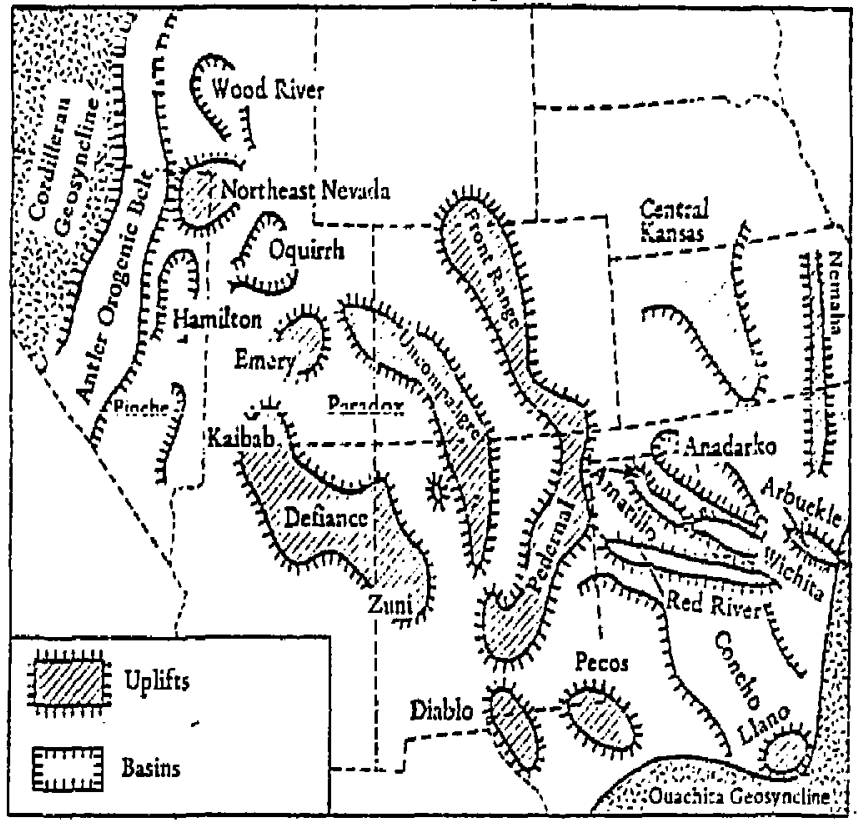

Figure 10: Distribution of Paleozoic structures in the Mid-Continent and Great glains Regions (From Mintz, 1977)

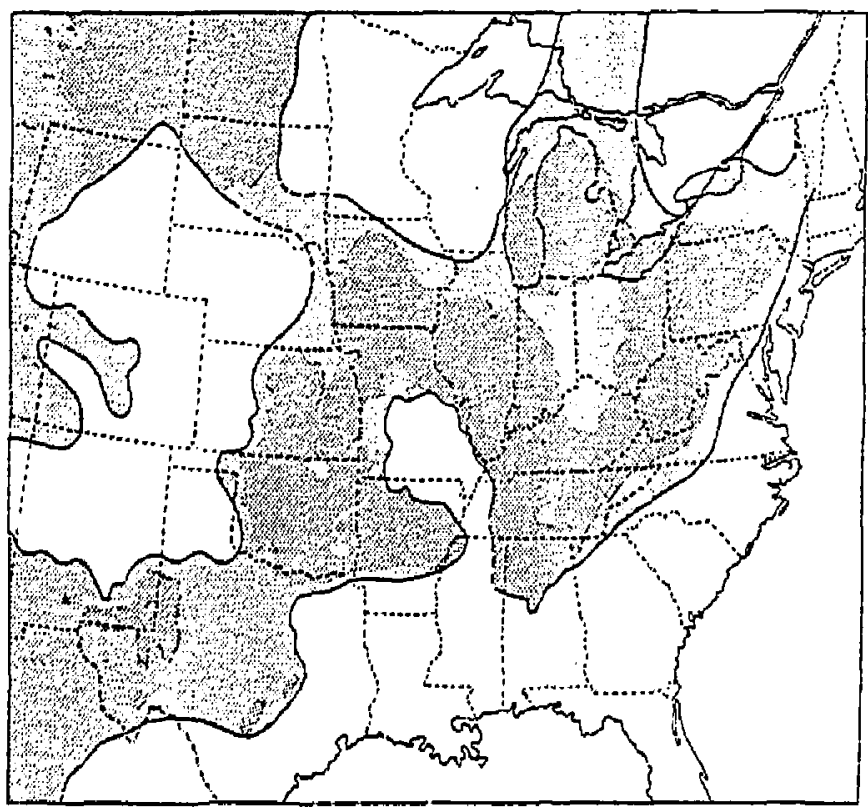

Figure 11: Map showing the distribution of the Chattanooga Shale (Devonian-Mississippian) in the United States (From Mintz, 1977). Darker shades show present extent of the unit. 


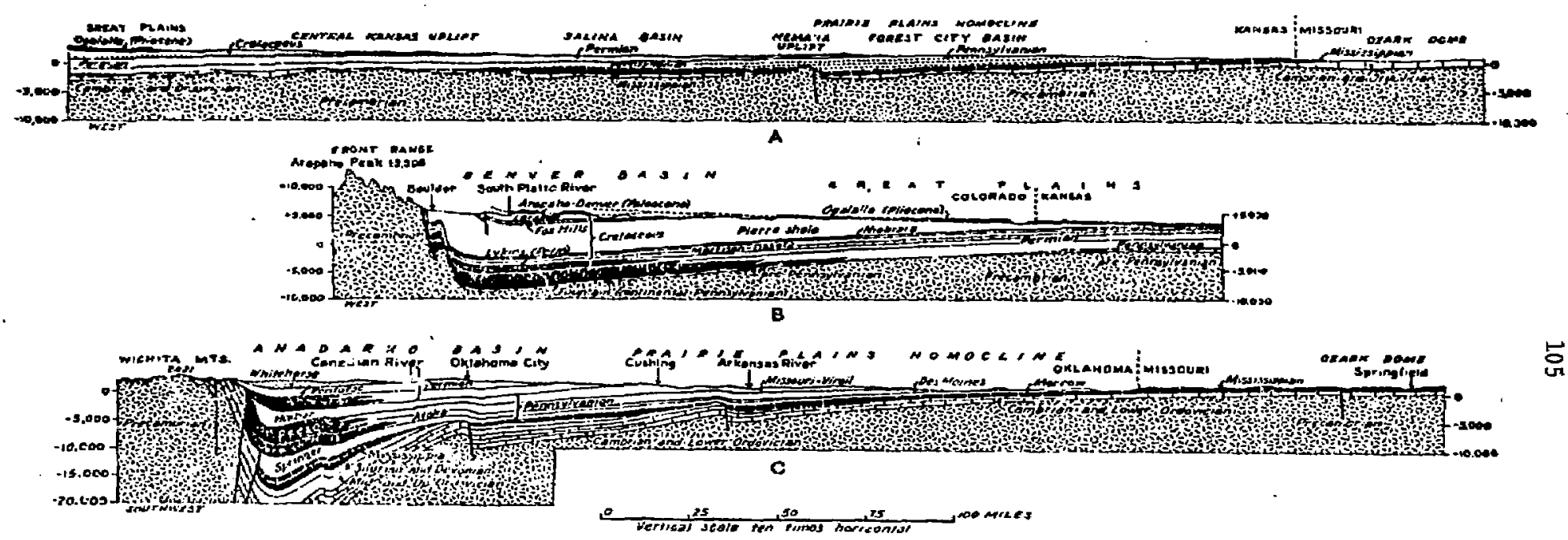

Figure 12: Sections illustrating structural relationships in the MidContinent and Great Plains regions. Top: Great Plains. Middle: Denver Basin, Bottom: Paleozoic Basins and domes (from King, 2951) 
TAELE 4-3 SUMMARY OF ROCK UNITS FROM THE MID-CONTINENT REGION [From Ruedeman (1939)]

NOTE: Shales described in the hydrologic tables are preceded by *.

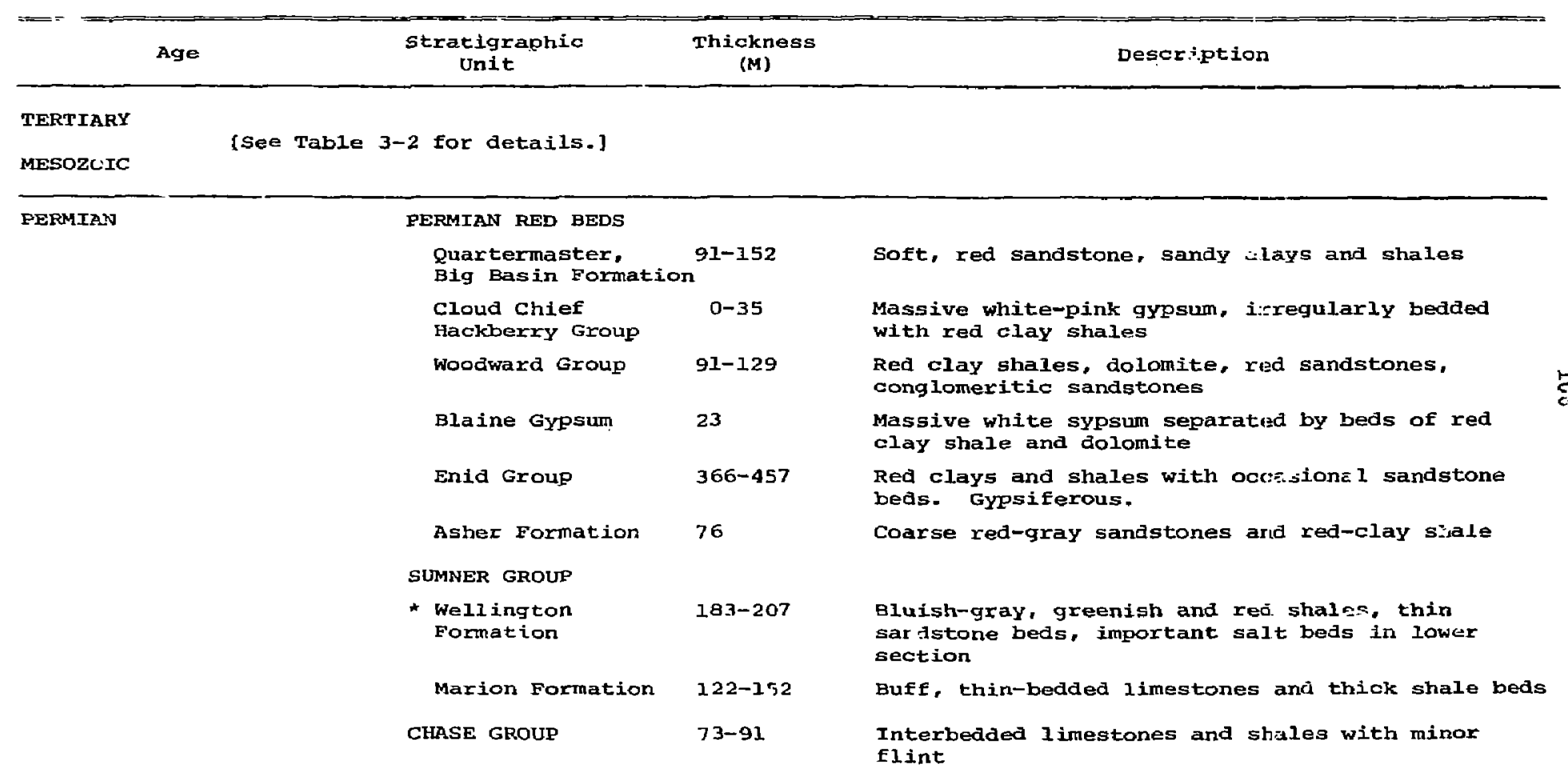


TABLE 4-3 (Continued)

\begin{tabular}{|c|c|c|c|}
\hline Age & $\begin{array}{l}\text { Stratigraphic } \\
\text { Unit }\end{array}$ & $\begin{array}{l}\text { Thickness } \\
\text { (M) }\end{array}$ & Descriptiouz \\
\hline \multirow[t]{2}{*}{ PERMIAN } & $\begin{array}{l}\text { Council-Grove } \\
\text { Group }\end{array}$ & 46 & $\begin{array}{l}\text { Massive shales, st.aly limestones, yellow shales } \\
\text { and thin limestones }\end{array}$ \\
\hline & $\begin{array}{l}\text { Eskridge Shale } \\
\text { Neva Limestones }\end{array}$ & $\begin{array}{l}12-23 \\
3-6\end{array}$ & $\begin{array}{l}\text { Green, grown, o= yellow shales } \\
\text { Massive gray limestone, one thin shale parting }\end{array}$ \\
\hline \multirow[t]{8}{*}{ PEAAISY LVANIAN } & Wabaunsee Group & 152 & Eight nembers, shales, sandstones and limestones \\
\hline & Shawnee Group & $211-352$ & $\begin{array}{l}\text { Nine members, cherty-argillaceous shales; limer- } \\
\text { stones, sandstones, some coal beds }\end{array}$ \\
\hline & Douglas Group & $107-267$ & $\begin{array}{l}\text { Four memt } \rightarrow \text { including Feston shale- Sandstones, } \\
\text { argiliac. } \\
\text { shales and limestones. }\end{array}$ \\
\hline & tansing Group & $38-76$ & $\begin{array}{l}\text { Four mernbers. Clayey to sandy shales and massive } \\
\text { limestones }\end{array}$ \\
\hline & * Chanute ShaIe & $8-31$ & clay shale to sandy shale \\
\hline & * Cherokee Formation & $137-305$ & $\begin{array}{l}\text { Variable colored shales with considerable litho- } \\
\text { logic variation }\end{array}$ \\
\hline & A+ $\because$ Formation & $60-2,134$ & $\begin{array}{l}\text { Shales with lenses and thin ledges of brown } \\
\text { sandstone }\end{array}$ \\
\hline & Wapanucka Limestone & $0-244$ & Eimestone, chert, sandstone, arrs shale. \\
\hline
\end{tabular}


TABLE 4-3 (Continuer)

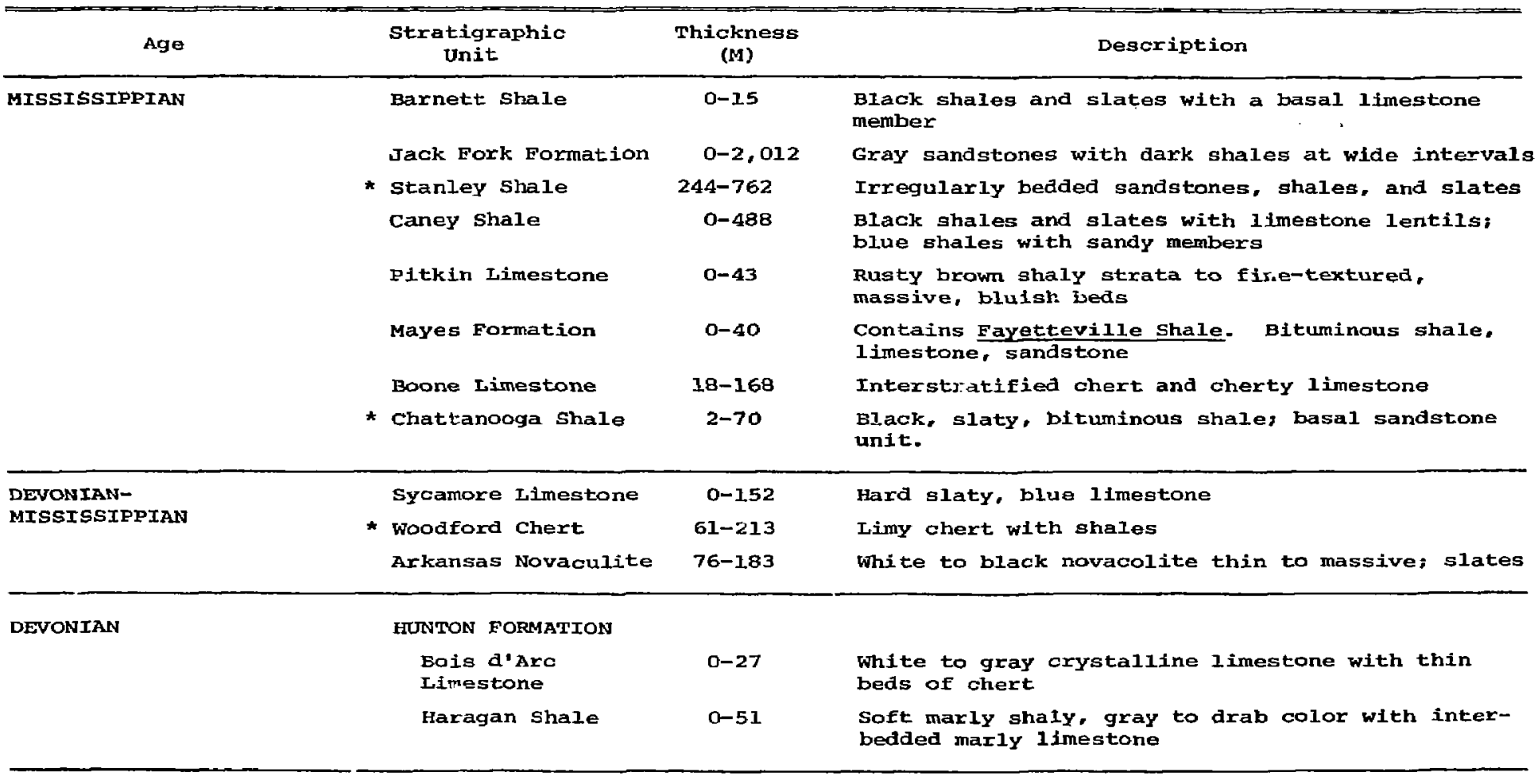


TABLE 4-3 (Continued)

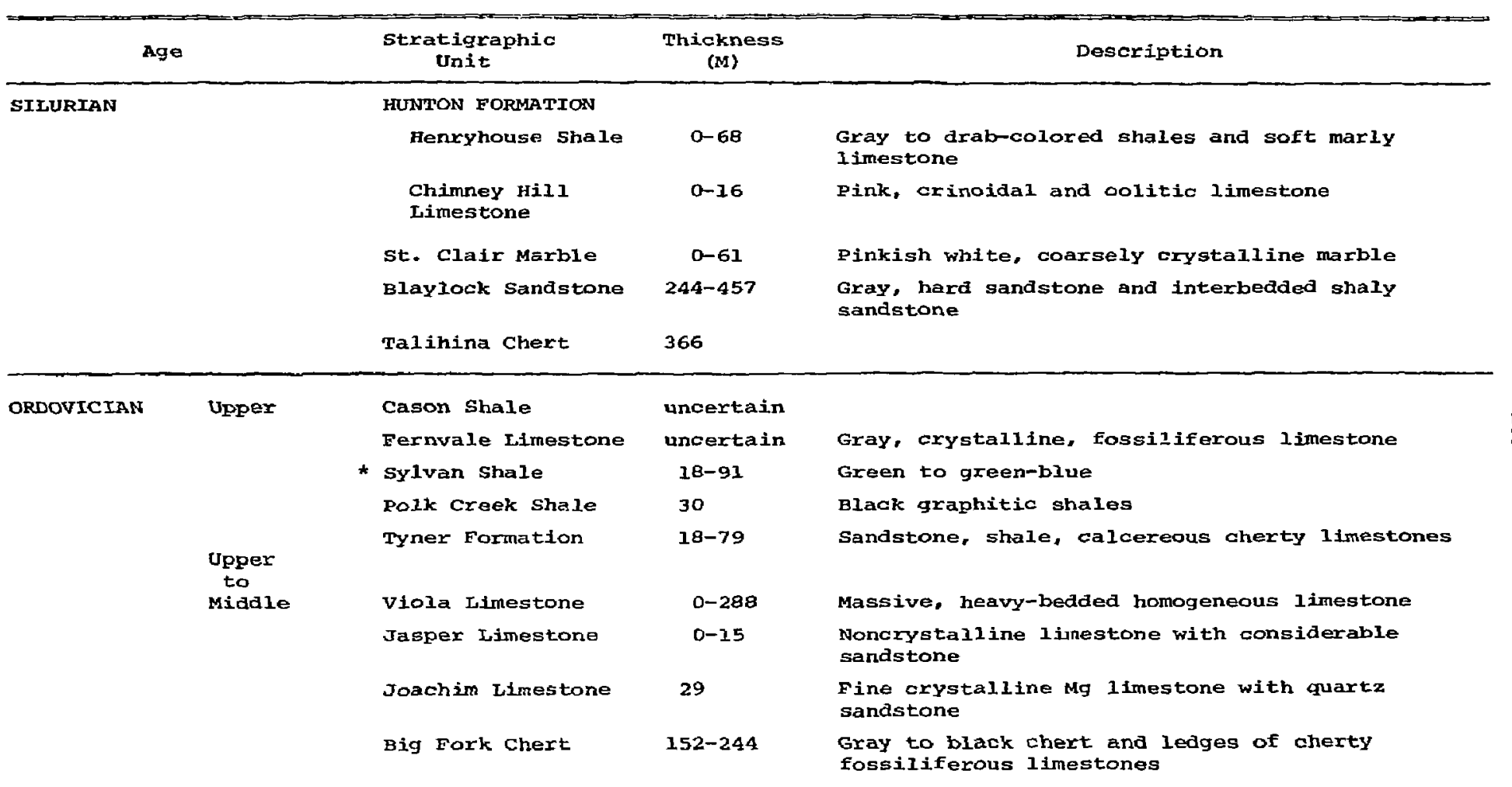


TABLE 4-3 (Continued)

\begin{tabular}{|c|c|c|c|c|}
\hline \multicolumn{2}{|c|}{ Age } & \multirow{2}{*}{$\begin{array}{l}\begin{array}{l}\text { Stratigraphic } \\
\text { Unit }\end{array} \\
\begin{array}{l}\text { Womble schistose } \\
\text { Sandstone }\end{array}\end{array}$} & \multirow{3}{*}{ 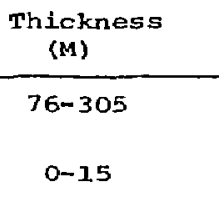 } & Description \\
\hline \multirow[t]{12}{*}{ MDON ICIAN } & Upper & & & $\begin{array}{l}\text { Micaceous, fine-grained sandstone interbedded } \\
\text { with shales }\end{array}$ \\
\hline & Midale & Blakely sandstone & & Gray sandstone and black and green shale \\
\hline & Lower & Simpson Group & $61-976$ & $\begin{array}{l}\text { Sandstones, thin limestones interbedded with } \\
\text { greenish clay. shales and marls }\end{array}$ \\
\hline & & st. Peter Sandstone & $0-61$ & Fine-grained, pooxly cemented sandstone \\
\hline & & YELVILLE FORMATION & & \\
\hline & & Everton Iimestone & $0-30$ & Fine-grained limestone, basal sandstone \\
\hline & & Powell Limestone & $0-6 I$ & Mg-Limestone, shale, basal conglonerate \\
\hline & & Cotter Dolomite & 152 & $\begin{array}{l}\text { Fine-grained, argillaceous dolonite; massive } \\
\text { medium-grained with shale and sandstone }\end{array}$ \\
\hline & & $\begin{array}{l}\text { Jefferson City } \\
\text { Dolomite }\end{array}$ & 183 & \\
\hline & & Mazarn shale & 305 & Dark, carbonaceous hard clay shales and slates \\
\hline & & $\begin{array}{l}\text { Crystal Mt. } \\
\text { sandstone }\end{array}$ & 259 & $\begin{array}{l}\text { Uniform, medium-grained, massive sandstone. } \\
\text { Basal conglomerate }\end{array}$ \\
\hline & & Arbuckle Limestone & $1,525-1,829$ & Thin-bedded to massive Mg-Limestone \\
\hline
\end{tabular}


TABLE 4-3 (Continued)

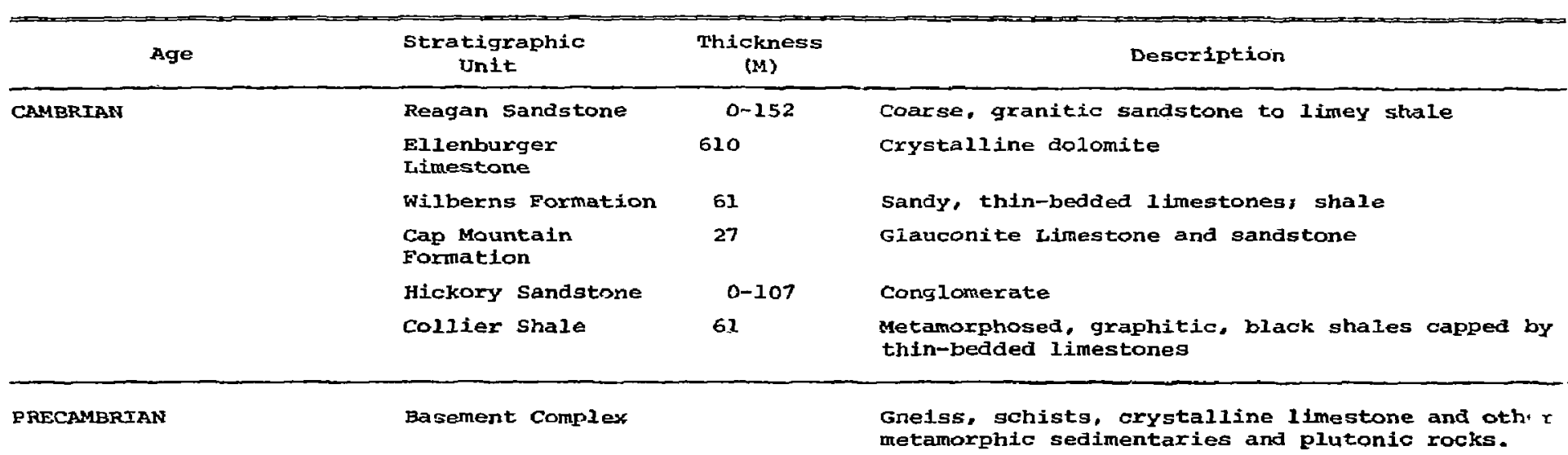




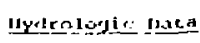

ReGion tit

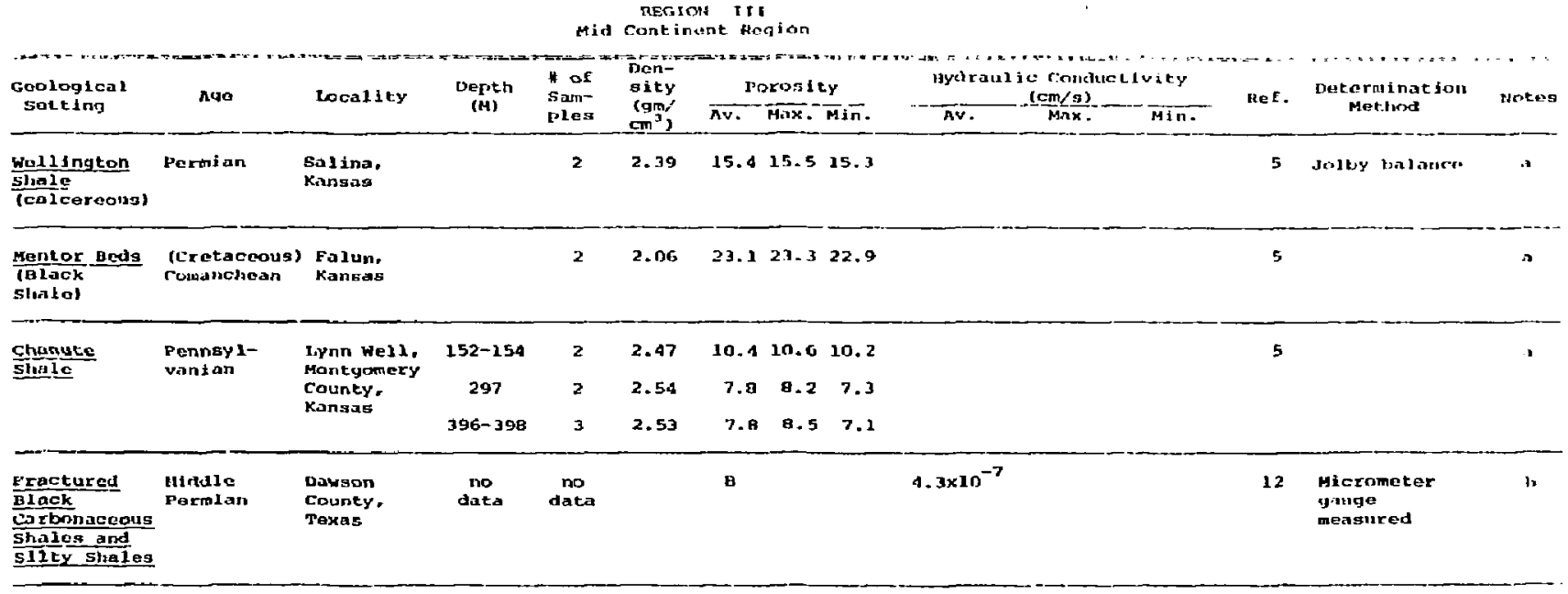

Inverayess frim vertical sequences.

Inducind fracturation to conduct ofl to well hore. 
REGION 131 (COnT Inu,

\begin{tabular}{|c|c|c|c|c|c|c|c|c|c|c|c|c|}
\hline \multirow{2}{*}{$\begin{array}{l}\text { Geological } \\
\text { Setting }\end{array}$} & \multirow[t]{2}{*}{ age } & \multirow[t]{2}{*}{ Locallty } & \multirow{2}{*}{$\begin{array}{l}\text { Depth } \\
(\mathrm{m})\end{array}$} & \multirow{2}{*}{$\begin{array}{l}\text { Hof } \\
\text { San- } \\
\text { plos }\end{array}$} & \multirow{2}{*}{$\begin{array}{l}\text { Don- } \\
\text { sity } \\
\text { (gm/ } \\
\left.\mathrm{cm}^{3}\right)\end{array}$} & Porasity & \multicolumn{3}{|c|}{$\begin{array}{c}\text { Hydraul te Cossaluctivity } \\
\text { (cm/s) }\end{array}$} & \multirow{2}{*}{ Rot. } & \multirow{2}{*}{$\begin{array}{l}\text { Determination } \\
\text { Metliod }\end{array}$} & \multirow{2}{*}{ instos } \\
\hline & & & & & & nv. Max. Min. & Av. & Ma): & Min. & & & \\
\hline Sliales & Permian & $\begin{array}{l}\text { Thomas } \\
\text { Pool, } \\
\text { Ok1alioma }\end{array}$ & Surface & & & 20 & & & & 3 & Hot stated & \\
\hline \multirow[t]{4}{*}{ Shales } & Pennzy1- & Ponce City & 350 & & 2.13 & 38 & & & & $\mathbf{2}$ & Graph & $r$ \\
\hline & & $\begin{array}{l}\text { roolsis } \\
\text { Oklationa }\end{array}$ & 300 & & 2.24 & 31 & & & & & & \\
\hline & & & 1230 & & 2.57 & o & & & & & & \\
\hline & & & 1930 & & & 4 & & & & & & \\
\hline Clionute & $\begin{array}{l}\text { Pujneys- } \\
\text { vantan }\end{array}$ & $\begin{array}{l}\text { Inde- } \\
\text { pentchico. } \\
\text { Kansas }\end{array}$ & $\begin{array}{l}\text { outcrops } \\
\text { (maleses. } \\
\text { quarries. } \\
\text { shat to } \\
\text { pits) }\end{array}$ & 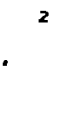 & 2.31 & 14.915 .014 .8 & & & & 5 & $\begin{array}{l}\text { lolly balameo } \\
\text { motliokl }\end{array}$ & d \\
\hline Hegtan & $\begin{array}{l}\text { Pennsyl- } \\
\text { vanjon }\end{array}$ & $\begin{array}{l}\text { Ionner } \\
\text { Springs, } \\
\text { Kansas }\end{array}$ & & 2 & $2.28 \$$ & 15.016 .015 .5 & & & & 5 & - & \\
\hline
\end{tabular}


REGION IT (Coutinued)

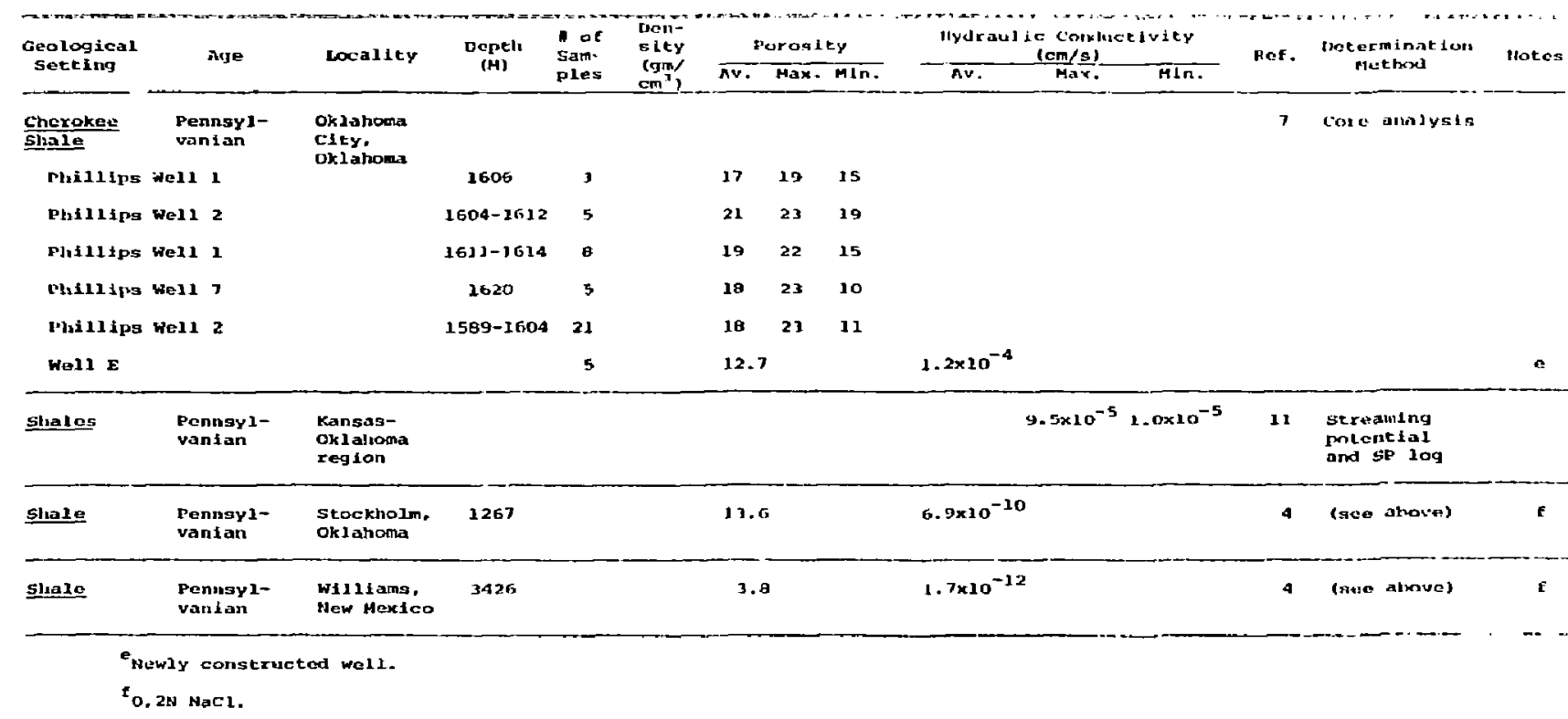




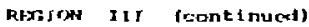

\begin{tabular}{|c|c|c|c|c|c|c|c|c|c|c|c|c|c|}
\hline \multirow{2}{*}{$\begin{array}{l}\text { Geological } \\
\text { Sotting }\end{array}$} & \multirow{2}{*}{ Aqe } & \multirow{2}{*}{ Locia Ity } & \multirow{2}{*}{$\begin{array}{l}\text { Dopth } \\
\text { (M) }\end{array}$} & \multirow{2}{*}{$\begin{array}{l}\text { Lof } \\
\text { Sam- } \\
\text { gles }\end{array}$} & \multirow{2}{*}{$\begin{array}{l}\text { Men- } \\
\text { oity } \\
\text { (gan' } \\
\text { cm }\end{array}$} & \multicolumn{2}{|c|}{ lorondty } & \multicolumn{3}{|c|}{$\begin{array}{l}\text { nyuraud te Condinet lufty } \\
(\mathrm{em} / \mathrm{s})\end{array}$} & \multirow{2}{*}{ Ref. } & \multirow{2}{*}{$\begin{array}{l}\text { vetermination } \\
\text { Methors }\end{array}$} & \multirow{2}{*}{ Notes } \\
\hline & & & & & & तu. & $\max \cdot \min$. & Av. & $\max$ & HIn. & & & \\
\hline Shale & $\begin{array}{l}\text { rennsyl- } \\
\text { vanian }\end{array}$ & $\begin{array}{l}\text { Hobbs } \\
\text { Whideat, } \\
\text { New Mexico }\end{array}$ & 2623 & & & 7.0 & & & & & 4 & $\begin{array}{l}\text { birect measure- } \\
\text { mant with a yas } \\
\text { purosimeter }\end{array}$ & \\
\hline Share & $\begin{array}{l}\text { Pemingy- } \\
\text { vanint }\end{array}$ & $\begin{array}{l}\text { Reagan } \\
\text { Coutity. } \\
\text { Toxas }\end{array}$ & & & & 6. 2 & & & & & 1 & & \\
\hline $\begin{array}{l}\text { Shales and } \\
\text { siltston: }\end{array}$ & Pormian & $\begin{array}{l}\text { Paduca, } \\
\text { New Mexico }\end{array}$ & 1412 & & & 20 & & & & $4.3 \times 10^{-6}$ & 2 & & $\mathbf{g}$ \\
\hline $\begin{array}{l}\text { Stanley } \\
\text { Sandgtone }\end{array}$ & $\begin{array}{l}\text { Pennsy 1- } \\
\text { vonian }\end{array}$ & $\begin{array}{l}\text { Ouachita } \\
\text { Mountaina, } \\
\text { Arkansas and } \\
\text { Ok lahoma }\end{array}$ & & & & & 0.5 & & $2 \times 10^{-5}$ & $4.3 \times 10^{-18}$ & 9 & & n \\
\hline
\end{tabular}

PGente tromochine, Gips to eagt. Turbidite saguence.

"Interbedded shales and sandstones. 
REG JOH ICT (contines)

\begin{tabular}{|c|c|c|c|c|c|c|c|c|c|c|c|c|c|}
\hline \multirow{2}{*}{ 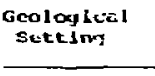 } & \multirow{2}{*}{ nge } & \multirow{2}{*}{ pocality } & \multirow{2}{*}{$\underset{\text { (M) }}{\text { molttil }}$} & \multirow{2}{*}{$\begin{array}{l}\text { of } \\
\text { sam- } \\
\text { ptes }\end{array}$} & \multirow{2}{*}{$\begin{array}{l}\text { sity } \\
\text { simp } \\
\operatorname{com}^{3} !\end{array}$} & \multicolumn{3}{|c|}{ Porosity } & \multicolumn{2}{|c|}{$\begin{array}{l}\text { Hydraul1e Conduct Ivity } \\
(\mathrm{cm} / \mathrm{s})\end{array}$} & \multirow{2}{*}{ Ref. } & \multirow{2}{*}{$\begin{array}{l}\text { Determinat isun } \\
\text { Mtethris }\end{array}$} & \multirow{2}{*}{ nores } \\
\hline & & & & & & Av. & Max. & $\overline{\text { Hin. }}$ & Av. Max. & $\min$. & & & \\
\hline \multirow[t]{5}{*}{ sluale } & \multirow{5}{*}{$\begin{array}{l}\text { Penmsy1- } \\
\text { vantall } \\
\text { and } \\
\text { Pormtan }\end{array}$} & \multirow{5}{*}{$\begin{array}{l}\text { Ponca cily } \\
\text { and Garber } \\
\text { Arass. } \\
\text { Oklahoma }\end{array}$} & 305 & & 2.25 & 17 & & & & & \multirow[t]{5}{*}{ B } & \multirow{5}{*}{$\begin{array}{l}\text { Dironit imeasure- } \\
\text { ment witli a } \\
\text { gas pxprosimeter }\end{array}$} & \\
\hline & & & 610 & & 2.42 & 11 & & & & & & & \\
\hline & & & 914 & & 2.52 & 7 & & & & & & & \\
\hline & & & 1219 & & 2.57 & 5 & & & & & & & \\
\hline & & & 1524 & & 2.62 & 4 & & & & & & & \\
\hline$\frac{\frac{\text { Duxycsas }}{\text { Sandstone }}}{(\text { Shata) }}$ & $\begin{array}{l}\text { Pennsy 1- } \\
\text { vantan }\end{array}$ & $\begin{array}{l}\text { South Hooxe } \\
\text { Fool. } \\
\text { okzahoma }\end{array}$ & $\begin{array}{l}2381- \\
238 n\end{array}$ & & & $3-4$ & & & & & $\boldsymbol{\theta}$ & & \\
\hline$\frac{\text { Shale }}{\text { (Heathored) }}$ & $?$ & $\begin{array}{l}\text { Neax Polca } \\
\text { C1ty. } \\
\text { oklahoma }\end{array}$ & & & & & 48 & 37 & & & B & & \\
\hline clay & 7 & $\begin{array}{l}\text { Near Ponca } \\
\text { C1ty. } \\
\text { oklahoms }\end{array}$ & & & & 53 & & & & & $\mathbf{B}$ & & 1 \\
\hline Shale & ? & oklaliname & & & & & & & $6.9 \times 10^{-10}$ & & 10 & Inalls. & 1 \\
\hline
\end{tabular}

Ju. 2n NaCl gulution uced as permeant. 
REGron III (conts Inued)

\begin{tabular}{|c|c|c|c|c|c|c|c|c|c|c|}
\hline \multirow{2}{*}{$\begin{array}{l}\text { Geological } \\
\text { Sotting }\end{array}$} & \multirow{2}{*}{ nge } & \multirow{2}{*}{ socality } & \multirow{2}{*}{ Depth } & \multirow{2}{*}{$\begin{array}{l}\text { Det- } \\
\text { sity } \\
\text { (gm/ } \\
\left.\mathrm{cm}^{3}\right)\end{array}$} & Porast ty & \multicolumn{2}{|c|}{$\begin{array}{l}\text { Hyctraulde Comluetivity } \\
(\mathrm{cm} / g)\end{array}$} & \multirow{2}{*}{ Ref. } & \multirow{2}{*}{$\begin{array}{l}\text { Dotorminat ton } \\
\text { Methed }\end{array}$} & \multirow{2}{*}{ Notess } \\
\hline & & & & & Av. Max. MIn. & Av. Max- & Min. & & & \\
\hline tenle & $?$ & $\begin{array}{l}\text { Horthern } \\
\text { Oxlahoma }\end{array}$ & & $\begin{array}{ll}\text { dry } & 2.15 \\
\text { gat } & <2.3 \mathrm{~J}\end{array}$ & $<20$ & & & $\mathbf{3}$ & & \\
\hline Sllaele & $?$ & $\begin{array}{l}\text { Northern } \\
\text { Oklatioma }\end{array}$ & & $\begin{array}{l}\text { dry }>2.55 \\
\text { sat } 2.59\end{array}$ & $<4$ & & & $\mathbf{3}$ & & \\
\hline$\frac{\text { Standey }}{\text { sllaie }}$ & $\begin{array}{l}\text { Pennsy 1- } \\
\text { vanian }\end{array}$ & $\begin{array}{l}\text { Ouachita } \\
\text { Mountem Ins, } \\
\text { Oklshomst }\end{array}$ & & $\begin{array}{c}2.45-2.60 \\
\text { dxy } \\
2.52-2.62 \\
\text { nat }\end{array}$ & $2.5-6.6$ & & & $\mathbf{3}$ & & \\
\hline $\begin{array}{l}\text { Eayerka- } \\
\text { yile Shale }\end{array}$ & $\begin{array}{l}\text { Missis- } \\
\text { gipian }\end{array}$ & $\begin{array}{l}\text { Ozark } \\
\text { Elateau, } \\
\text { Oklohoma }\end{array}$ & & $\begin{array}{c}2.27-2.44 \\
\text { dry } \\
2.41-2.53 \\
\text { bat }\end{array}$ & a.6-14.1 & & & 3 & & \\
\hline $\begin{array}{l}\text { Syluan } \\
\text { Shale }\end{array}$ & Ordoulcian & $\begin{array}{l}\text { Murray } \\
\text { County. } \\
\text { Oklalioinn }\end{array}$ & outcrop & 日 & $39.94-43.30$ & & & 6 & rab. & k \\
\hline
\end{tabular}

kistribution coefficients availabio in reference 6. 
REGION III (eONE InUAI)

\begin{tabular}{|c|c|c|c|c|c|c|c|c|c|c|c|c|c|c|}
\hline \multirow{2}{*}{$\begin{array}{l}\text { Geological } \\
\text { setting }\end{array}$} & \multirow[t]{2}{*}{ Aye } & \multirow{2}{*}{ Locallty } & \multirow{2}{*}{$\begin{array}{l}\text { Dept!1 } \\
\text { (H) }\end{array}$} & \multirow{2}{*}{$\begin{array}{l}\text { Pof } \\
\text { Saln- } \\
\text { plos }\end{array}$} & \multirow{2}{*}{$\begin{array}{l}\text { orex- } \\
\text { sity } \\
(9 \mathrm{~m} / \\
\left.\mathrm{cm}^{3}\right)\end{array}$} & \multicolumn{3}{|c|}{ Parosity } & \multicolumn{3}{|c|}{$\begin{array}{c}\text { Mydraulic Conductivicy } \\
(\mathrm{cm} / \mathrm{s})\end{array}$} & \multirow{2}{*}{ Ref. } & \multirow{2}{*}{$\begin{array}{l}\text { Determination } \\
\text { Method }\end{array}$} & \multirow{2}{*}{ Nestes } \\
\hline & & & & & & $\overline{n u .}$ & Max. & Hin. & Av. & $\frac{\mathrm{Sm} / \mathrm{s})}{\operatorname{Max} .}$ & $\overline{M i n .}$ & & & \\
\hline shale & 8 & $\begin{array}{l}\text { Phi111ps } \\
\text { Wall, p Count } \\
\text { Ruasel count } \\
\text { Kansus }\end{array}$ & $\begin{array}{l}427-453 \\
t Y .\end{array}$ & 4 & 2.15 & 22.5 & $2 x .3$ & 22.0 & & & & $\mathbf{a}$ & & $\mathbf{1}$ \\
\hline $\begin{array}{l}\text { Clianuke } \\
\text { Sliaie }\end{array}$ & $\begin{array}{l}\text { Pennoyk- } \\
\text { vantan }\end{array}$ & $\begin{array}{l}\text { Muntgomery } \\
\text { County, } \\
\text { Kangas }\end{array}$ & $752-297$ & 4 & 2.51 & 9.1 & 10.6 & 7.3 & & & & $\mathbf{a}$ & & 1 \\
\hline
\end{tabular}

1 Total poroselty. 
1. Athy, F. L., 1930, Density, Porosity, and Compaction of Sedimentary Rocks: Bull. Am. Assoc. Pet. Geol., v. 14, PD. 1-24.

2. Berg, R. R., 1975, Capillary Pressure in Stratigraphic Traps: Am. Assoc. Pet. Geol. Bull. v. 59, P. 939-956.

3. Birch, F., Schaixer, J. F.. and Spicex, C. H., 1942, Handbook of Physical Constants: Geological Society of America, Special Paper No. $36,325 \mathrm{p}$.

4. Gondouin, M., and Scala, C., I958, Streaming Potential and the SP Log: Trans. A.I.M. I... v. 213, p. $170-179$.

5. Hedberg. H. D., 1926, The Effect of Gravitational Compaction on ti.e structure of sedimentary Rocks: Bul1. Am. AssoC. Pet. Geol.r. v. 10, PP. 1035-1072.

6. Jennings, A. R., and Schroeder, M. C., 1968, Laboratory Evaluation of Sulected Radiolsotopes as Ground-Water Tracers: Water Resources Research, v. 4, no. 4, pp. 829-838.

7. Katz, D. I., 1942, Possibilities of secondary Recovery for the oklahoma city wilcox Sand: Trans. A.I.M.E., V. 146, D. $28-53$.

8. Manger. E. G., 1963, Porostty and Bulk Density of Sedimentary Rocks: U. S. Geological Survey Bulletin 1144-E, $55 \mathrm{p}$.

9. Morris, R. C.: Proctor, K. E., and Koch, M. R., 1977, Petrology and Diagenesis of Deep-Water Sandstones, Ouachita Mountains, Arkansas and oklahoma Abstr: A.A.P.G. Bull.. V. 61, P. 1384.

10. Ritke, Herman H. III, and Chilingarion, George $V ., 1974$, Compaction of Axgillaceous Sediments: Developments in Sedimentology, v. 16, 424 p.

11. Schenck, K. D., An Investigation of the Streaming Potential Developed in Formations of Iow Permeability, M.S. Thesis, University of Oklahoma, 1955.

12. Wilkinson, W. M., 1953, Fracturing in Sprayberry Reservoir, West Texas: Bull. Am. Assoc. Pet. Geo:. v. 37, p. 250-265. 
REGION 4: THE GULF COAST AND THE MISSISSIPPI EMBAYMENT

The southeastern coast of the United States is characterized by a Paleozoic episode of plate convergence following by a history of diverging plates which began with the Triassic and is continuing today.

With the end of the Faleozoic, ancestral North America and Europe collided with Gondwanaland (Seyfert and Sirkin, 1973) after closing of the Theic Ocean. This collision resulted in the frimation of the Appalachian belt and its southern extension into the Gulf Coast area, the Marathon-ouachita Mountains. After a brief continental episode (Permian) curing which evaporites were formed, subsidence and deposition of a clastic wedge began to take place in response to the opening of the Atlantic Ocean. Most clastic sediments are Mesozoic and Cenozoic, and the shales are regarded as the likely source of the Gulf coast oil and gas fields (many were formed by salt dome tectonics). Although most shales are Tertiary and Cretaceous, Paleozoic units, more representative of Appalachian and Mid Continent regions occasi ally crop out around the periphery of the basin or in domal uplifts. Figure 13 shows typical relationships of this region. 


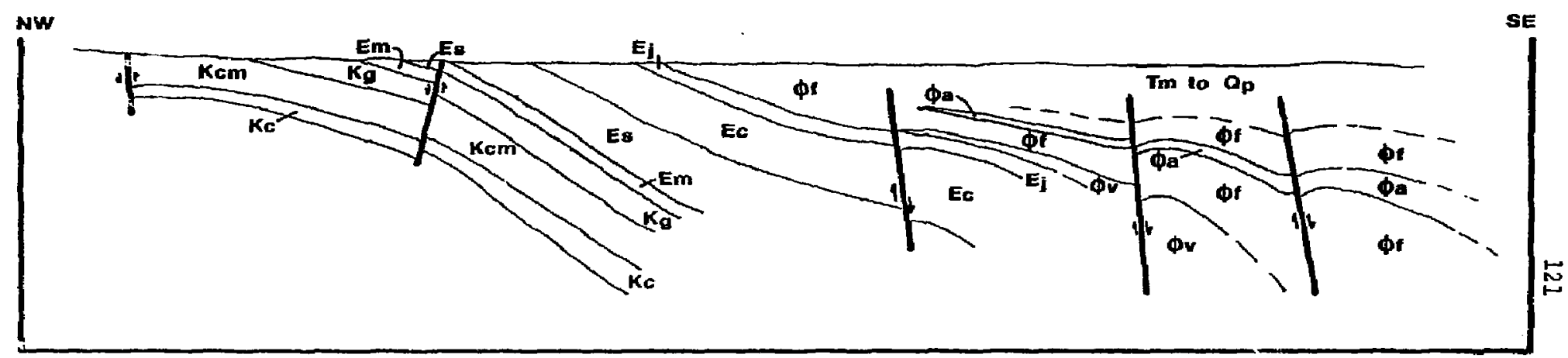

Figure 13: Section across the Gulf Coast clastic wedge (After Murray, 1: 61).

Ko: Coahuila Series; Kom: Comanche Series; Kg: Gulf Series;

$\mathrm{Em}$ : Midway stage; Es: Sabine stage; Ec: clairborne stage:

$\mathrm{Ej}$ : Jackson Stage; $\phi \mathrm{V}$ : Vicksburg stage; $\phi F$ : Frio Fromation:

中a: Anahvac Form; Tmpp-Mio-Plio-Pleistocene. 
NOTE: Units described in the hydrologic tables are prededed by *.

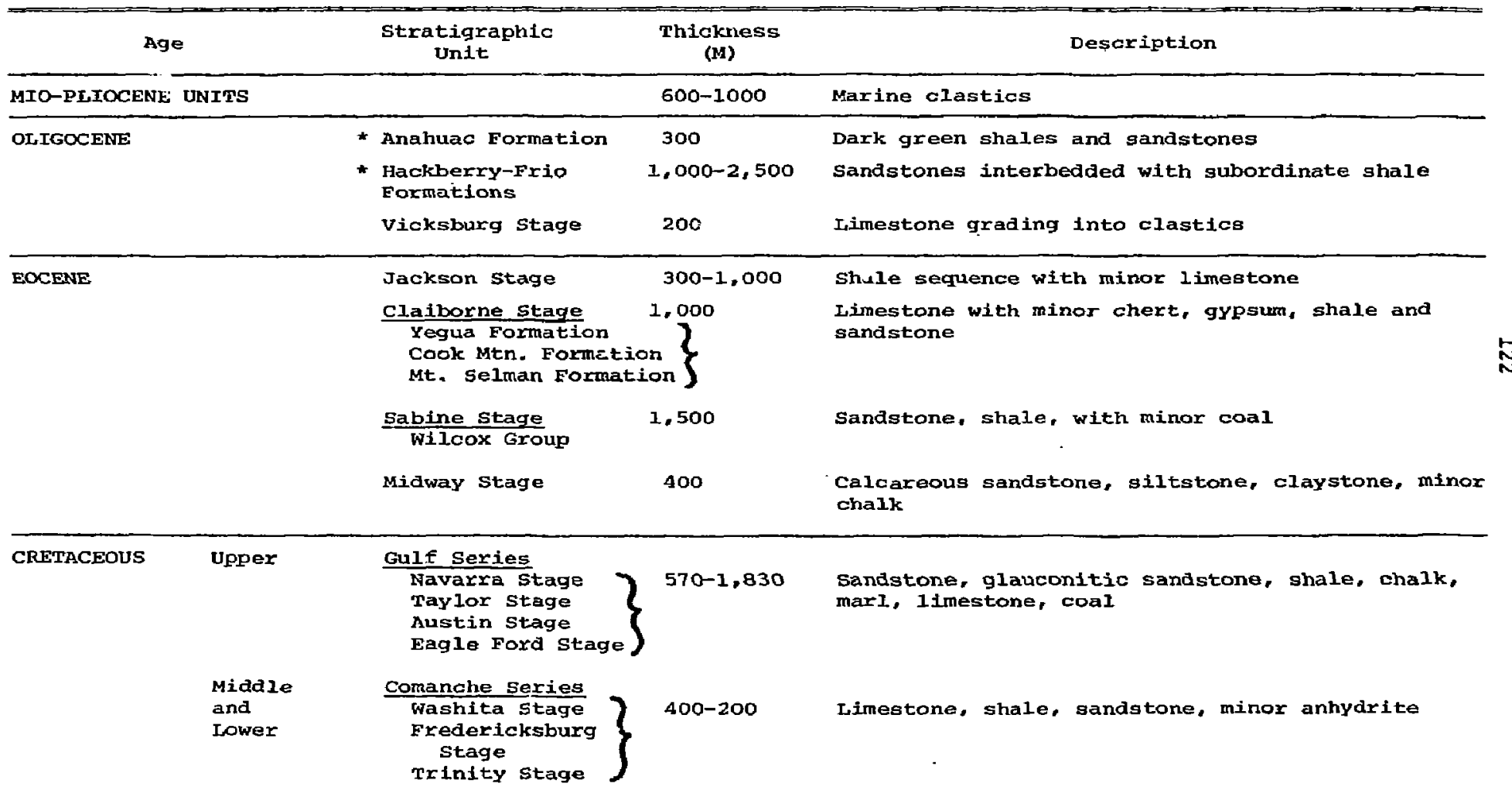


TABLE 4-4 (Continued)

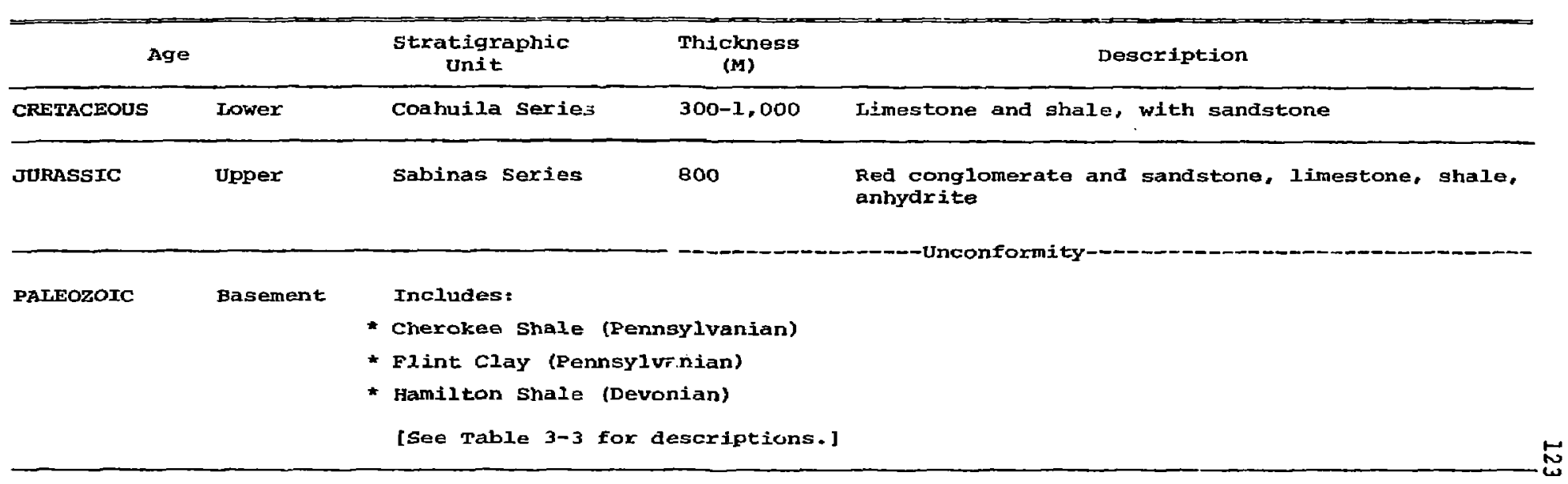


Eyaleninule varten

RTE SON IV

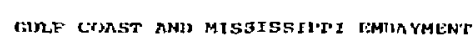

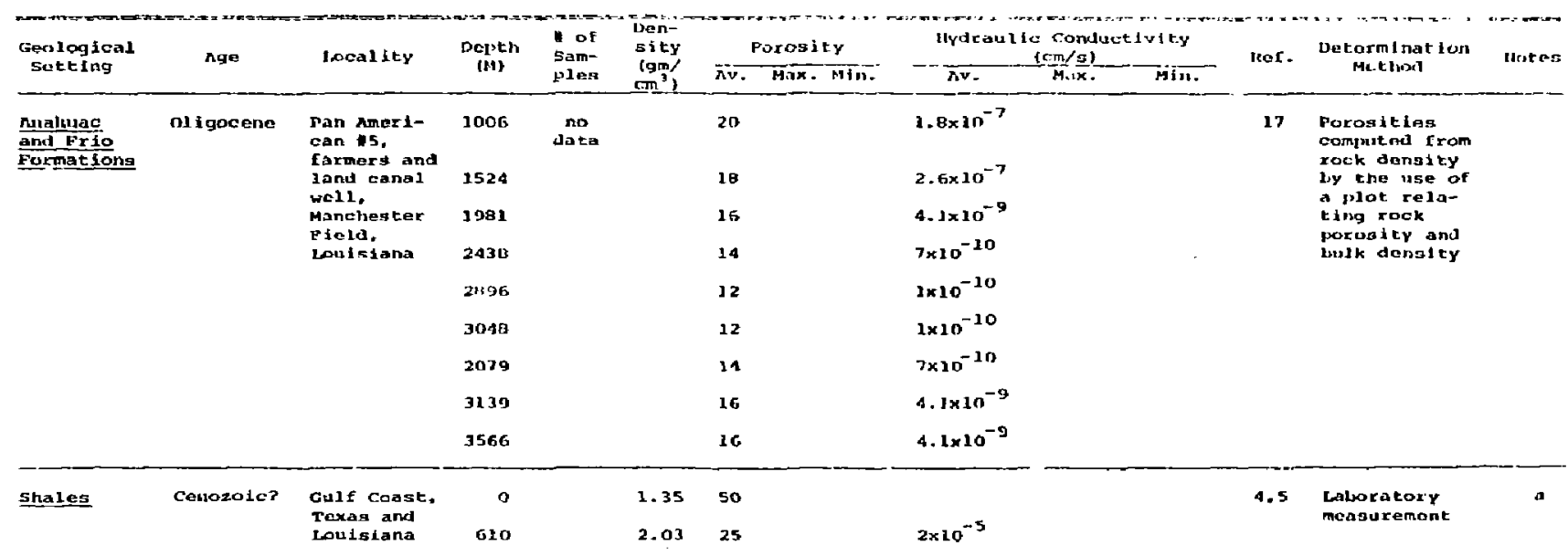

Trypical wall parameters. 
RHEIDH IV (contimmed)

\begin{tabular}{|c|c|c|c|c|c|c|c|c|c|c|c|c|}
\hline \multirow{2}{*}{$\begin{array}{l}\text { Goological } \\
\text { sytting } \\
\end{array}$} & \multirow{2}{*}{ nge } & \multirow{2}{*}{ Lcacalley } & \multirow{2}{*}{$\begin{array}{l}\text { Dopth } \\
\text { (A) }\end{array}$} & \multirow{2}{*}{$\begin{array}{l}\text { Wof } \\
\text { Sann- } \\
\text { ples }\end{array}$} & \multirow{2}{*}{$\begin{array}{l}\text { sity } \\
\left(\mathrm{gmm}^{2}\right) \\
\left.\mathrm{smm}^{3}\right)\end{array}$} & Porosity & \multicolumn{3}{|c|}{$\begin{array}{l}\text { Hydraudic Conductivity } \\
(\mathrm{cm} / \mathrm{s})\end{array}$} & \multirow{2}{*}{ kaf. } & \multirow{2}{*}{$\begin{array}{l}\text { vetormination } \\
\text { Hothod }\end{array}$} & \multirow{2}{*}{ Nerters } \\
\hline & & & & & & Av. Max. Min. & Av. & Max. & Mtn. & & & \\
\hline \multirow[t]{9}{*}{ (Shates) } & Cesrozoic & Gulf Const, & 1220 & & 2.11 & 22 & & & - & 4.5 & & \\
\hline & Gretaceons & Loistana & $18: 0$ & & 2.19 & 19 & & & & & & \\
\hline & & & 244 ? & & 2.27 & 16 & & & & & & \\
\hline & & & 3049 & & 2.35 & 13 & & & & & & \\
\hline & & & 3659 & & 2.43 & 10 & & & & & & \\
\hline & & & 1269 & & 2.43 & 10 & & & & & & \\
\hline & & & $487 B$ & & 2.46 & 9 & & & & & & \\
\hline & & & 5480 & & 2.46 & 9 & & & & & & \\
\hline & & & Gixans & & $2.4 \pi$ & $\pi$ & & & & & & \\
\hline
\end{tabular}


REGTON IV (contimisent)

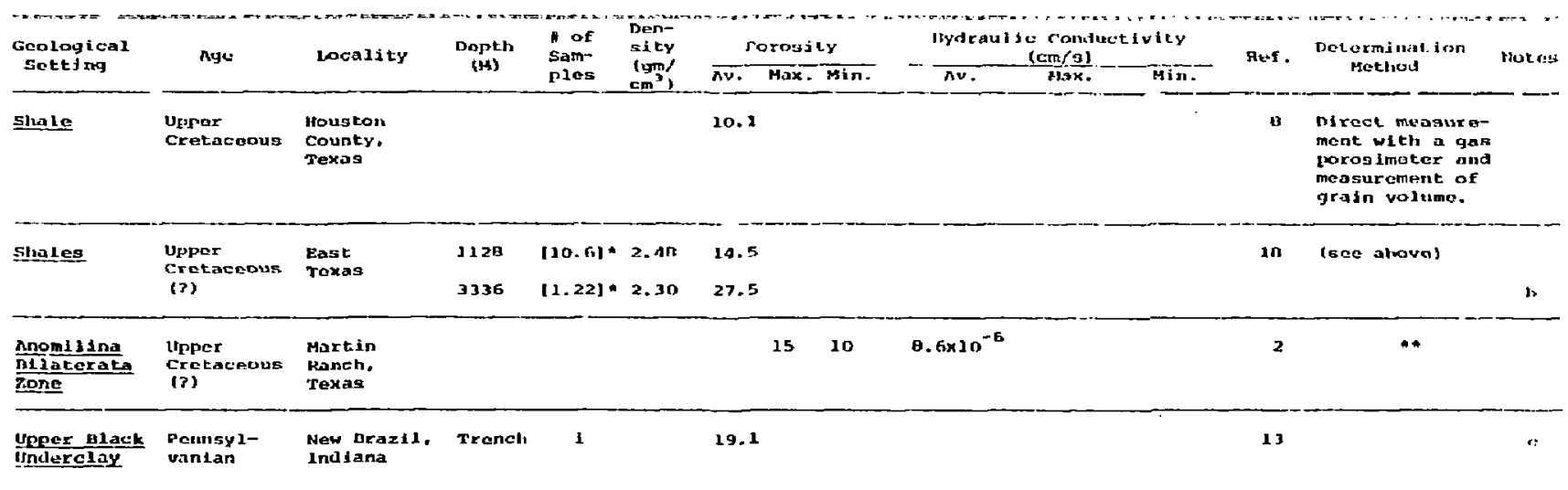

b sllale a sigtivity at $25^{\circ} \mathrm{C}$ and offective gtross of 1000 pat.

"Total pou salty.
- restsetuliey (olun m) s.c.

- -strale-sambetone cycle

Shalos - Topset

foolta Front sine le-Says

nrodolta Shale - Base

Chacolate bayou Fleld 
REGTOS TV (continume)

\begin{tabular}{|c|c|c|c|c|c|c|c|c|c|c|c|c|}
\hline \multirow{2}{*}{$\begin{array}{l}\text { Ceological } \\
\text { Setting }\end{array}$} & \multirow{2}{*}{ Age } & \multirow{2}{*}{$20=01$ it $y$} & \multirow{2}{*}{$\begin{array}{l}\text { neptli } \\
\text { (M) }\end{array}$} & \multirow{2}{*}{$\begin{array}{l}\text { tor } \\
\text { sum } \\
\text { ples }\end{array}$} & \multirow{2}{*}{$\begin{array}{l}\text { Don- } \\
\text { sity } \\
\text { (gmat } \\
\left.\operatorname{com}^{3}\right) \\
\end{array}$} & Parosidty & \multicolumn{3}{|c|}{$\begin{array}{c}\text { Mydrawl be Conthetivit.y } \\
(\mathrm{Ccm} / \mathrm{s})\end{array}$} & \multirow{2}{*}{ Ref. } & \multirow{2}{*}{$\begin{array}{l}\text { Determinat fon } \\
\text { Methits3 }\end{array}$} & \multirow{2}{*}{ Notens } \\
\hline & & & & & & Av. Max. Min. & nv. & $\operatorname{Max}$ & Ant. & & & \\
\hline $\begin{array}{l}\text { Consolidaated } \\
\text { sandy Silpie }\end{array}$ & - & $\begin{array}{l}\text { South } \\
\text { Taxas }\end{array}$ & $\begin{array}{l}2513- \\
2514\end{array}$ & 3 & & 23 & $5.1 \times 10^{-5}$ & & & $\mathbf{2}$ & $\begin{array}{l}\text { Elcekrfen l } \\
\text { rasintivity } \\
\text { data }\end{array}$ & d \\
\hline \multirow[t]{4}{*}{ 해aㅣㄹㅡ } & $\begin{array}{l}\text { vernisyl- } \\
\text { vanfian }\end{array}$ & $\begin{array}{l}\text { Centralin } \\
\text { Fleld, } \\
\text { rlitioins }\end{array}$ & 425 & & & 14.2 & -1 & $1.7 \times 10^{12)}$ & 8. $5 \times 10^{-12}$ & B & $\begin{array}{l}\text { Streaning } \\
\text { potentelei } \\
\text { artl sp lox }\end{array}$ & c \\
\hline & & $\begin{array}{l}\text { Colorada } \\
\text { County, } \\
\text { Texas }\end{array}$ & 2761 & & & 7.4 & $2.6 \times 10^{-50}$ & $3.4 \times 10^{-12}$ & - & & & \\
\hline & & $\begin{array}{l}\text { Houston } \\
\text { County. } \\
\text { Texas }\end{array}$ & 7 & & & & $0, \tan 10^{-13}$ & $6 \times 10^{-12}$ & - & & & \\
\hline & & $\begin{array}{l}\text { Clark } \\
\text { County. } \\
\text { IIIInoio }\end{array}$ & 143 & & & & $7.7 \times 10^{-6}$ & - & - & & & \\
\hline$\frac{\text { Clieroken }}{\text { sliala }}$ & $\begin{array}{l}\text { Penney1- } \\
\text { vanian }\end{array}$ & $\begin{array}{l}\text { Eultan, } \\
\text { Missours }\end{array}$ & outerop & 2 & 2.29 & 17.117 .217 .0 & & & & 9 & $\begin{array}{l}\text { Melcher } \\
\text { Method }\end{array}$ & \\
\hline
\end{tabular}

deorintion resiativity factor $\rightarrow 14$.

(1) 0. O2N NaCl

(2) 0.2N NaCl

(3) in Nac: 
Flacion IV (cent 1muad)

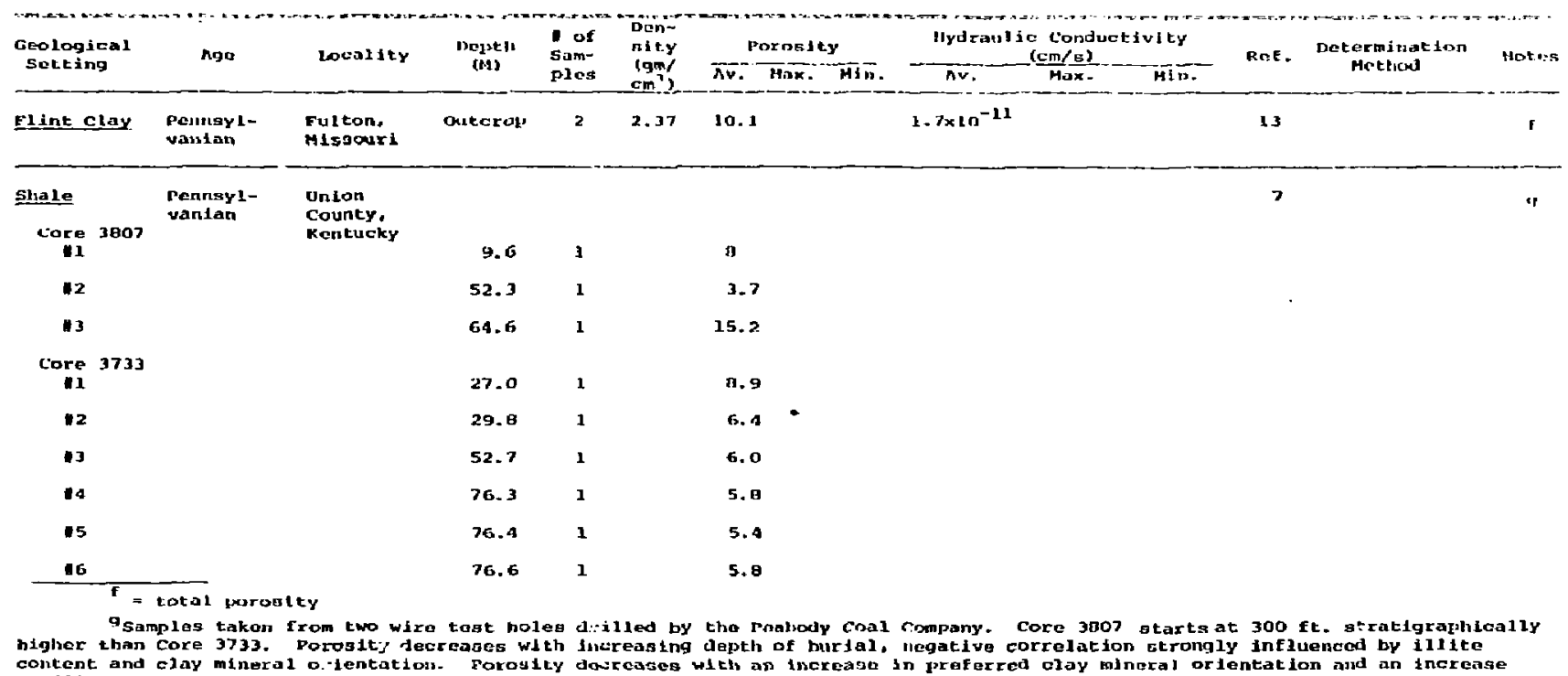


MEGIOH IV (contsmica)

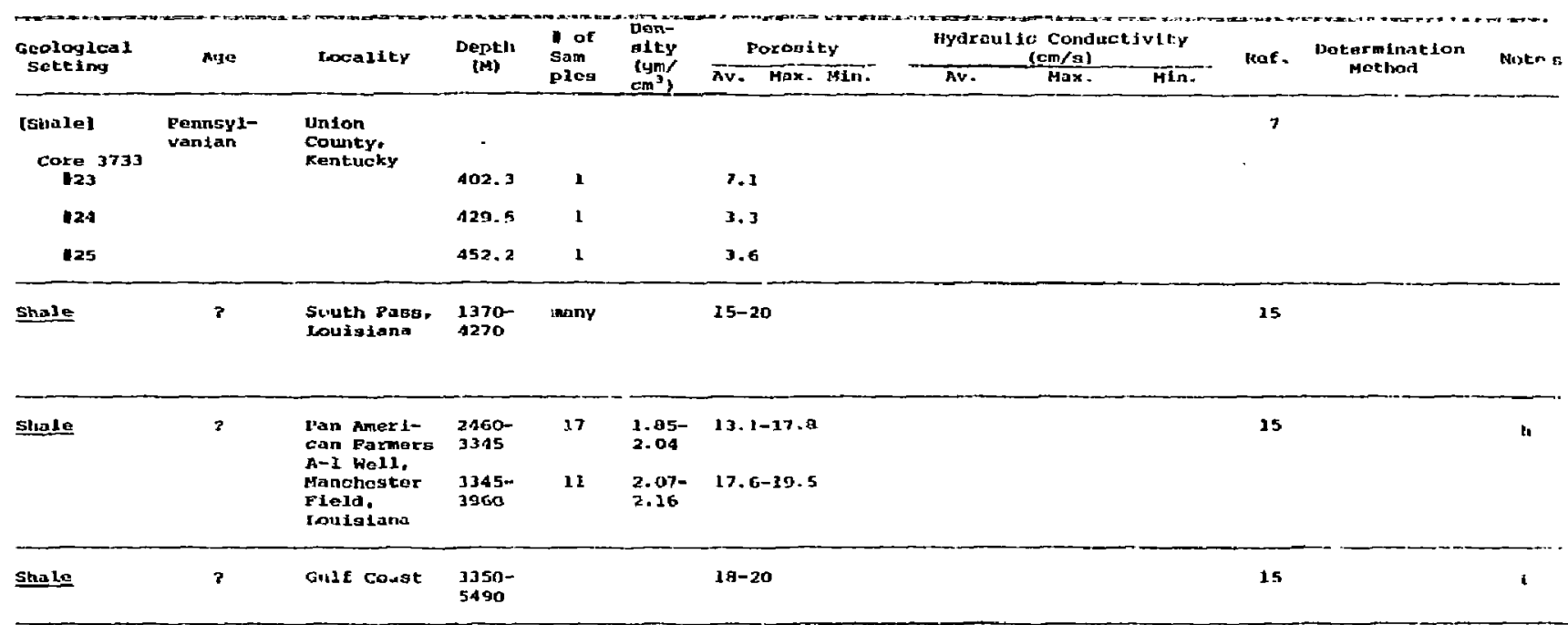

"porosity and density canges

1 Porosity measured in tab using shalo chips. 
RETION iv (continume

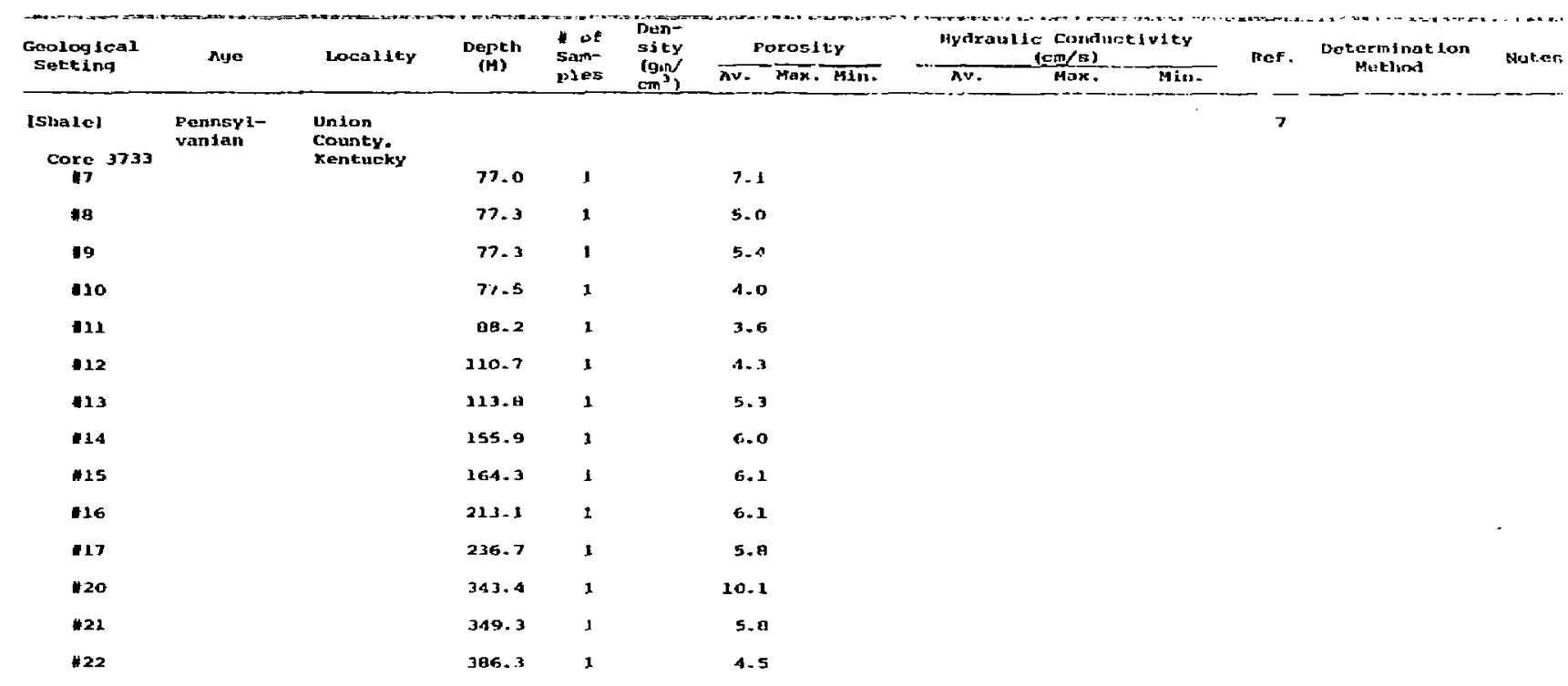




\begin{tabular}{|c|c|c|c|c|c|c|c|c|c|c|c|}
\hline \multirow{2}{*}{$\begin{array}{l}\text { Geologieal } \\
\text { settivg }\end{array}$} & \multirow{2}{*}{ Ago } & \multirow{2}{*}{ locastity } & \multirow{2}{*}{$\begin{array}{l}\text { Depth } \\
\text { (M) }\end{array}$} & \multirow{2}{*}{$\begin{array}{l}\text { Eof } \\
\text { Srum- } \\
\text { prles }\end{array}$} & \multirow{2}{*}{$\begin{array}{l}\text { hen- } \\
\text { sily } \\
\left(\mathrm{gmg}^{\prime}\right) \\
\left.\mathrm{cm}^{3}\right)\end{array}$} & Porogiky & \multicolumn{2}{|c|}{$\begin{array}{l}\text { Hydraul Le Comluct ivity } \\
(\mathrm{cm} / \mathrm{g})\end{array}$} & \multirow{2}{*}{ Ret. } & \multirow{2}{*}{$\begin{array}{l}\text { Determluat Ion } \\
\text { Method }\end{array}$} & \multirow{2}{*}{ Hokes } \\
\hline & & & & & & Av. Max. Nitn. & Av: Hax. & AIn. & & & \\
\hline Shale & 7 & $\begin{array}{l}\text { Toxas GuLf } \\
\text { Coabt }\end{array}$ & 3510 & & & 20 & & & 15 & & \\
\hline Shale & 7 & $\begin{array}{l}\text { Louisiana } \\
\text { Gulf coast }\end{array}$ & $\begin{array}{l}3390- \\
5400\end{array}$ & 71 & & $10.8-22.5$ & & & 15 & & \\
\hline \multirow[t]{2}{*}{ Shale } & $?$ & Gulf coagt & $\begin{array}{l}121- \\
3688\end{array}$ & 55 & & $7.5-45$ & & & 11 & & \\
\hline & & & $\begin{array}{l}579- \\
4267\end{array}$ & 23 & & $11-34$ & & & & & \\
\hline Slialo & 7 & Texas & & & & & $6 \times 10^{-12}$ & & 16 & lab & i \\
\hline \multirow[t]{4}{*}{ Shale } & 7 & Gulf coast & & & & 3 & $7.7 \times 10^{-14}$ & & 10 & Lalu. & \\
\hline & & & & & & 3 & $1.3 \times 10^{-19}$ & & 10 & Lill. & \\
\hline & & & & & & - & $8.58 \times 10^{-15}$ & & 16 & Lanlx. & \\
\hline & & & & & & - & $2.1 \times 10^{-15}$ & & 16 & Int & $\mathrm{k}$ \\
\hline
\end{tabular}

Jo. 2H Nacl solution used as permeant.

* 10,000 psi load. 


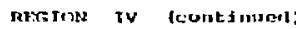

\begin{tabular}{|c|c|c|c|c|c|c|c|c|c|c|}
\hline \multirow{2}{*}{$\begin{array}{l}\text { Geological } \\
\text { sotting }\end{array}$} & \multirow[t]{2}{*}{ nye } & \multirow[t]{2}{*}{ Locality } & \multirow{2}{*}{$\begin{array}{l}\text { nepth } \\
\text { (H) }\end{array}$} & \multirow{2}{*}{$\begin{array}{l}\text { DoE } \\
\text { Sam- } \\
\text { zlez }\end{array}$} & \multirow{2}{*}{ 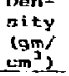 } & Purosiley & $\begin{array}{l}\text { Myolraulie condugetivity } \\
\text { (cm/s) }\end{array}$ & \multirow[t]{2}{*}{ Ref. } & \multirow{2}{*}{$\begin{array}{l}\text { Dimeerinsination } \\
\text { Metlisad }\end{array}$} & \multirow{2}{*}{ Notes } \\
\hline & & & & & & Max. & nv. Max. Mlï. & & & \\
\hline \multirow[t]{2}{*}{ [shale] } & 7 & Guif cuast & - & - & - & 3 & $3.3 \times 10^{-9}$ & $1-$ & Lab. & \\
\hline & & & $\begin{array}{l}1216- \\
4257\end{array}$ & & & $14-20$ & $1.7 \times 10^{-10}$ to $1.8 \times 10^{-13}$ & 12 & I.als. & 1 \\
\hline $\begin{array}{l}\text { Green 1sh } \\
\text { shale }\end{array}$ & $?$ & $\begin{array}{l}\text { Slureveport, } \\
\text { Jouigiana }\end{array}$ & & $\begin{array}{ll}\text { ar } \\
\text { so }\end{array}$ & $\begin{array}{l}2.30 \\
2.33\end{array}$ & 22.6 & & 3,14 & & m \\
\hline
\end{tabular}

\begin{tabular}{|c|c|c|c|c|c|c|}
\hline$\frac{\text { Reldisli }}{\text { Shale }}$ & 7 & $\begin{array}{l}\text { Shraveport. } \\
\text { Loulatans }\end{array}$ & $\begin{array}{ll}\text { ary } 2.22 \\
\text { sat } 2.42\end{array}$ & 20.0 & 3.14 & 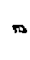 \\
\hline Sthale & 8 & $\begin{array}{l}\text { Shroveport, } \\
\text { Loulatana }\end{array}$ & $\begin{array}{l}\text { Ary } 2.29 \\
\text { sat } 2.46\end{array}$ & 16.9 & 3.14 & $n$ \\
\hline Shale & $?$ & $\begin{array}{l}\text { Batosutile. } \\
\text { Ackansas }\end{array}$ & $\begin{array}{ll}\text { dry } & 2.05 \\
\text { sat } & 2.06\end{array}$ & 1.5 & 3 & \\
\hline
\end{tabular}

Istimates from graph fox under-compacted shale.

m Just above pay sand of curtis 1.

"Deep gas sand of lboxges ward 1. 


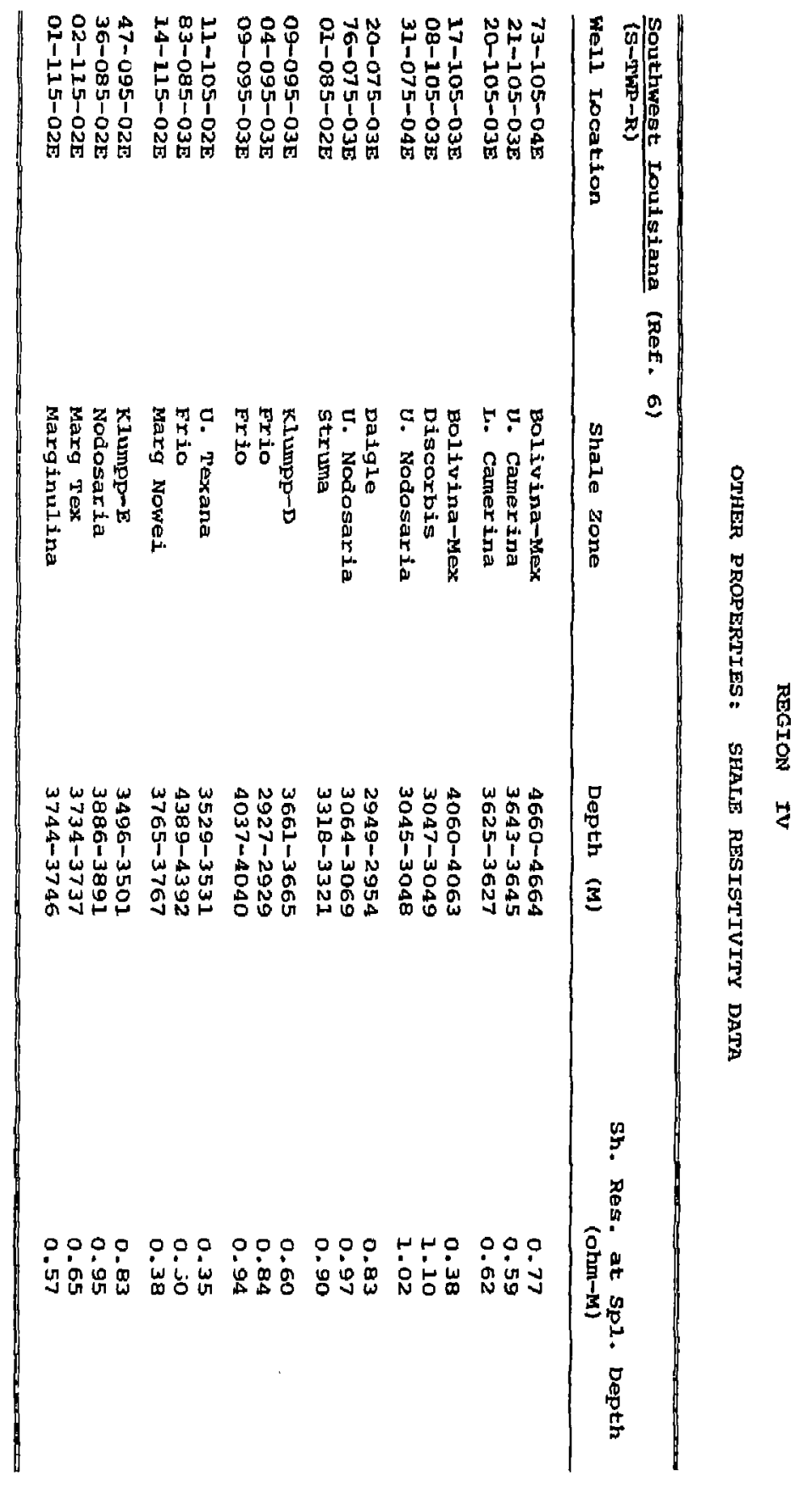


1. Archie, C. E., 1947, Electrical Resistivity an mia in Core-Ana, fis Interpretation: Am. Assoc. Pet. Geol. Bull., v. 31, p. 350-366.

2. Bedoubt, D. G.. and Gregory, A. R., 1977, Texas Geothermal Project Slated to Begin Operations at Maxtin Ranch: ㅇil \& Gas Journel, v. 75, no. 41, p. 184-187.

3. Birch, F.; Schairex, J. F., and Spicer, C. H., 1942, Handbook of. Prysical Constants: Geological Society of Americe, Special Paper no. 36, 325 p.

4. Bradley. J. S., 1975, Abnormal Formation Pressure: Amer. Assoc. Pet. Geol. Bull., v. 59, P. $957-973$.

5. Dickey, P. A., 1976, Abnormal Formation Pressure: Discussion: Amer. Assoc. Pet. Geol., v. 60, p. 1124-1128.

6. Dickey, P. A., Collins, A. G., and Fajarado, I., 1972, Chemical Composition of Deep Formation Waters in Southwestern Louisiana: A.A.P.G. Bull., V. 56, P. 1530-1533.

7. Gipson, Mack, I-., 1966, A study of the Relations of Depth, Porosity, and clay Mineral Orientatión in Pennsylvanian Shales: Jour. of Sedimentary Petrology, $v .36$, no. 4, PP. 888-903.

8. Gondouin, M., and Scala, C., 1958, Streaming Potential and the SP Log: Trans. A.I.M.E.. v. 213 , p. $170-179$.

9. Hedberg, H. D., 1925, The Effect of Gravitational compaction on the structure of Sedimentary Rocks: Bull. Am. Assoc. Pet. Geol, v. 10, pF, 1035-1072.

10. Hubbert, M. K. and Rubey, W. W., 1959, Role of Fluid Pressure in Mechanics of Overthruat. Faulting, II. Overthrust Belt in Geosynclinal Area of Western Wyoming in Light of FluidPressure Hypothesis: Geological Society of America Bulletin, v. 70, no. 2, pp. 167-206. 
REGION IV: REFERENCES (continued)

11. Magira, K., 1971, Permeability Considerations in Generation of Abnormal Pressures: Society of Petroleum Engineers Journa2, v. 11, pp. 236-242.

22. Magára, K., 1974, Compaction, Ion Filtration, and osmosis in shale and Their significance in Primary Migration: Amer. Assoc. of Petroleum Geologists Bulletin, v. 58, no. 2, pp. 283-290.

13. Manger, E. G., 1963, Porosity and Bulk Density of Sedimentary Rocks: U. S. Geological Survey Brlietin 1144-E, $55 \mathrm{P}$.

14. Melcher, A. F., 1921, Determination of Pore Space of oil and Gas Sands: Trans. Am. Inst. Min. Es:- v, 65, PP. 480-489.

15. Price, L. C., 1976, Aqueous Solubility of Petroleum as Applied to its origin and Primary Migration: American Association of Petroleum Geologists Bulletin, v. 60, no. 2, pp. 213-244.

16. Rieke, Hexman I. LII, and Chilingarion, George V., 1974, Compaction of Axgillaceous sediments: Developments in Sedimentology, v. 16, $424 \mathrm{p}$.

17. Schnidt, G. W., 1973, Interstitill Water Composition and Geochemistry of Deep Gulf Coast Shales and Sandstones: Am. Assoc. Pet. Geol. Bull., v. 57, Pp. 321-337.

18. Waxman, M. H., and Thomas, E. C., 1975, Electrical Conauctivities of Shaly Sands - I. The Relation Between Hydrocarbon Saturation and Resistivity Index: II. The Temperature Coefficient of Electrical Conductivity: A.I.M.E. Trans, v. 257, P. 213-225. 
REGION 5: THE APPALACHIAN MOUNTAINS AND THE GREAT LARES

The north and eastern portion of the United States has evolved, much like the Gulf Coast, along two opposing trends. During the Paleozoic, the geologic history has been characterized by collisions of plates, disappearance of proto-oceans, and building of one supercontinent (Pangea). In Late Devonian time, the northern Appalachians (New England) were formed as the Iapetus ocean disappeared (Mintz, 1977). In Late Carboniferous time the southern Appalachian-Ouachita range formed a weld between Laurasia and Gondwanaland (closing the Theic ocean), but this union was short lived: with the advent of the Triassic the two continents began to part their ways as the Atlantic Ocean started to grow.

Record of these geologic events has been preserved in the form of Upper Precambrian and Paleozoic remnants of oceanic basins folded into Appalachian structures and of Triassic red beds (Newark Series) occupying graben-like basins. The following shales are found within this geologic record:

-Iate Precambrian (Nonsuch shale), Late Ordovician (Martinsburg shale), and Devonian Mississippian (Chattanooga shales), all three characterize the early compressive tectonic style. Their relationship is illustrated in Fig. 14.

-Triassic (Brunswick shale) is more representative of a setting found in the Atlantic Plains, which are discussed in the next region. 
Maynardville quadrongle

Knoxville quadrangle

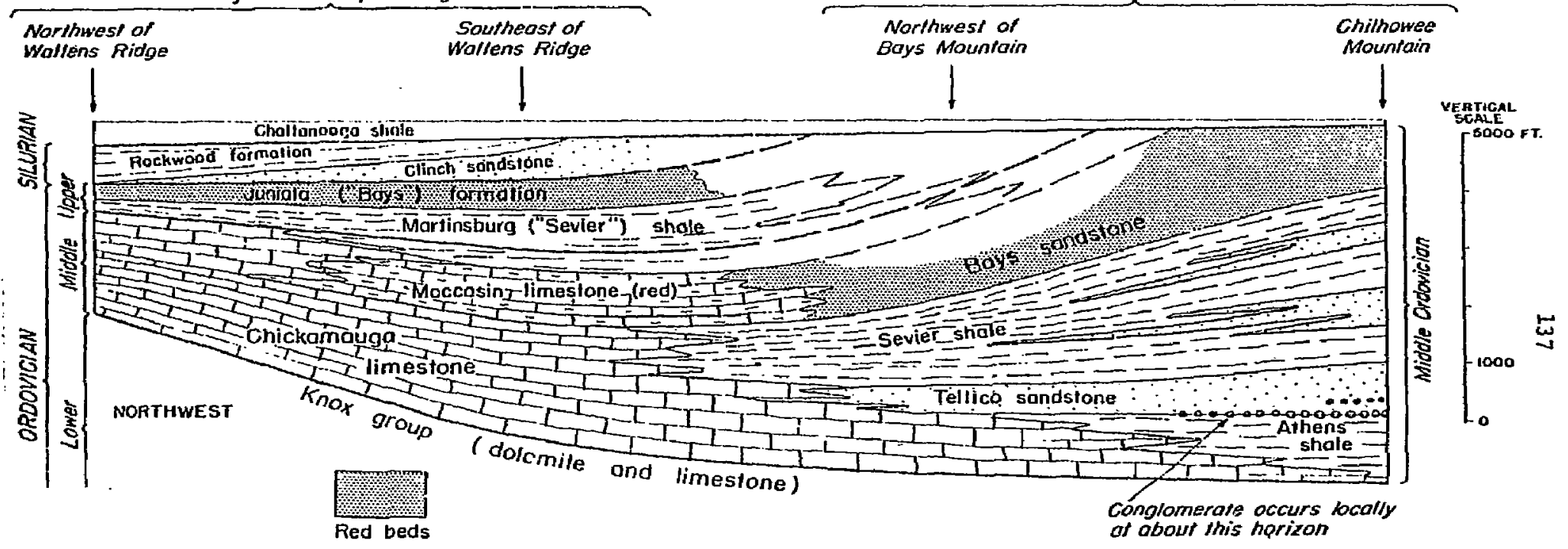

Figure 14: Stratigraphic diagram showing the relationships between the Martinsburg and Chattanooga shales in the Appalachian, Great Lakes Region (After Eardley, 1962) 
TABLE 4-5 SLMMARY GF ROCK UNITS OF THE APPALACHIAN AND GREAT LAKES REGION

[F'rom schucher (1943)]

NOTE: Units described in the hydrologic tables are prededed by *.

\begin{tabular}{|c|c|c|c|c|}
\hline Age & & $\begin{array}{l}\text { Stratigraphic } \\
\text { unit }\end{array}$ & $\begin{array}{l}\text { Thickness } \\
\text { (M) }\end{array}$ & Description \\
\hline $\begin{array}{l}\text { LOWER PERMIAN } \\
\text { AND UPPER } \\
\text { PENNSYEVANIAN }\end{array}$ & & $\begin{array}{l}\text { Cassaville and } \\
\text { Washington } \\
\text { Formations }\end{array}$ & $0-366$ & $\begin{array}{l}\text { Brown and red sandstone, shale, thin limestone } \\
\text { and unimportant coals }\end{array}$ \\
\hline \multirow[t]{4}{*}{ PENNSYLVANIAN } & Upper & $\begin{array}{l}\text { * Nonongahela } \\
\text { Iormation }\end{array}$ & $79-91$ & Shale, limestone, sandstone, and coals \\
\hline & Middle & $\begin{array}{l}\text { Conemaugh } \\
\text { Formation }\end{array}$ & $122-244$ & $\begin{array}{l}\text { Red shale, massive pebbly sanastone, with coals } \\
\text { and fire clays }\end{array}$ \\
\hline & & $\begin{array}{l}\text { * Allegheny } \\
\text { Formation } \\
\text { (Flint Clay?) }\end{array}$ & $85-122$ & Sandstone, shale, limestone, coals, fire clays \\
\hline & Lower & Pottsville Group & $91-1,265$ & Sanäztone, ghale, coals \\
\hline \multirow[t]{4}{*}{ MISSISSIPPIAN } & Upper & $\begin{array}{l}\text { Mauch Chunk } \\
\text { Formation }\end{array}$ & $91-1,052$ & $\begin{array}{l}\text { Green sandstone, interbedded with red and green } \\
\text { shale }\end{array}$ \\
\hline & & $\begin{array}{l}\text { Greenbriex } \\
\text { Formation }\end{array}$ & $247-549$ & Fossiliferous limestone, with red and green shale \\
\hline & Middle & Maccrady Group & $7-107$ & $\begin{array}{l}\text { Red, purple and yellow shale, earthy limestone, } \\
\text { and calcereous sandstone }\end{array}$ \\
\hline & Lower & Pocono Formation & $213-668$ & $\begin{array}{l}\text { Gray or red sandstone, sandy shale, unimportant } \\
\text { coal }\end{array}$ \\
\hline
\end{tabular}


TABLE 4-5 (Continued)

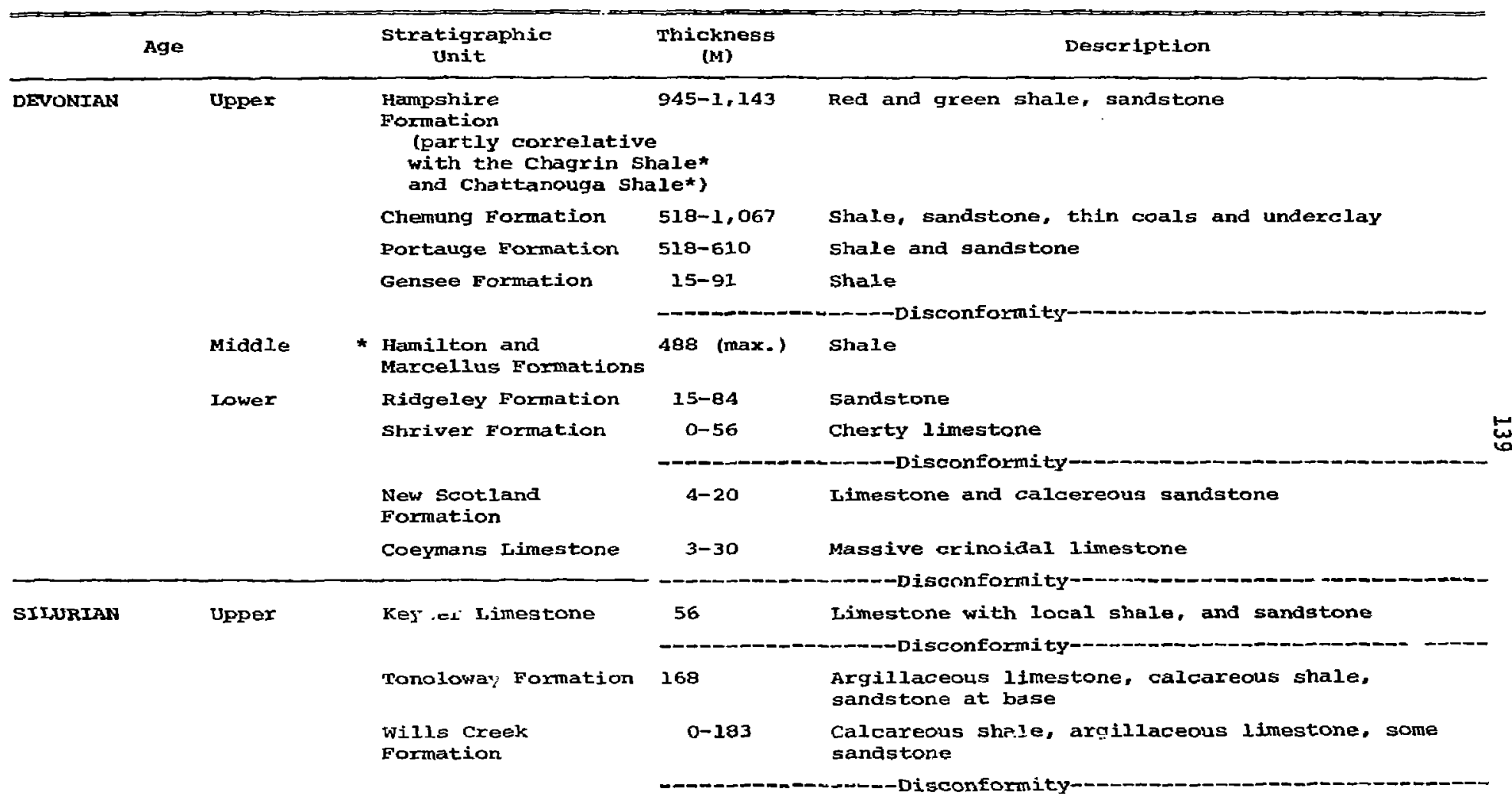


TABLE 4-5 (Continued)

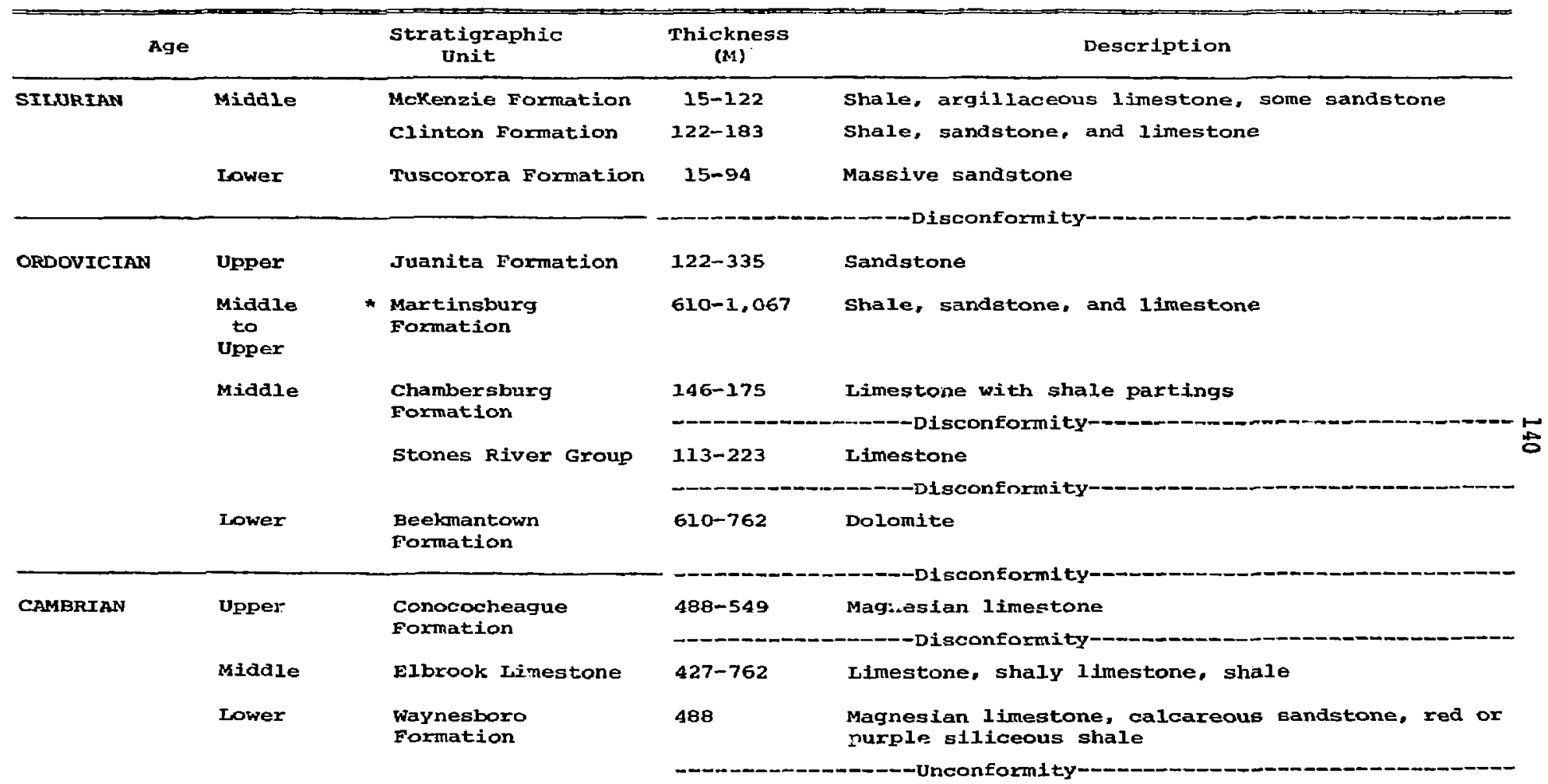


TARIE 4-5 (Continued)

\begin{tabular}{|c|c|c|c|c|}
\hline Ag & & $\begin{array}{c}\text { Stratigxaphic } \\
\text { unit }\end{array}$ & $\begin{array}{c}\text { Thickness } \\
\text { (M) }\end{array}$ & Description \\
\hline CAHBRTAN & Iower & $\begin{array}{l}\text { Tomstown Formation } \\
\text { Antietam Formation } \\
\text { Harpers Formation } \\
\text { Weverton Formation }\end{array}$ & $\begin{array}{l}111-319 \\
152 \\
366 \\
152-183\end{array}$ & $\begin{array}{l}\text { Dolomite, marble, limestone and shale } \\
\text { Quartzite, sandstone } \\
\text { slate, quartzite } \\
\text { Quartzite, conglomerate }\end{array}$ \\
\hline PFECAMBRTAN & Uppermost & $\begin{array}{l}\text { Keweenawan } \\
\text { (Includes Nonesuch } \\
\text { Formation) }\end{array}$ & $\begin{array}{l}16,500 \\
12,200 \\
100\end{array}$ & $\begin{array}{l}\text { Lava flows, red sandstone and shales } \\
\text { Black shale }\end{array}$ \\
\hline
\end{tabular}

PROTEROZOIC

AND EARITER 
MYMUISAR;LE DATA

regions $y$

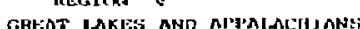

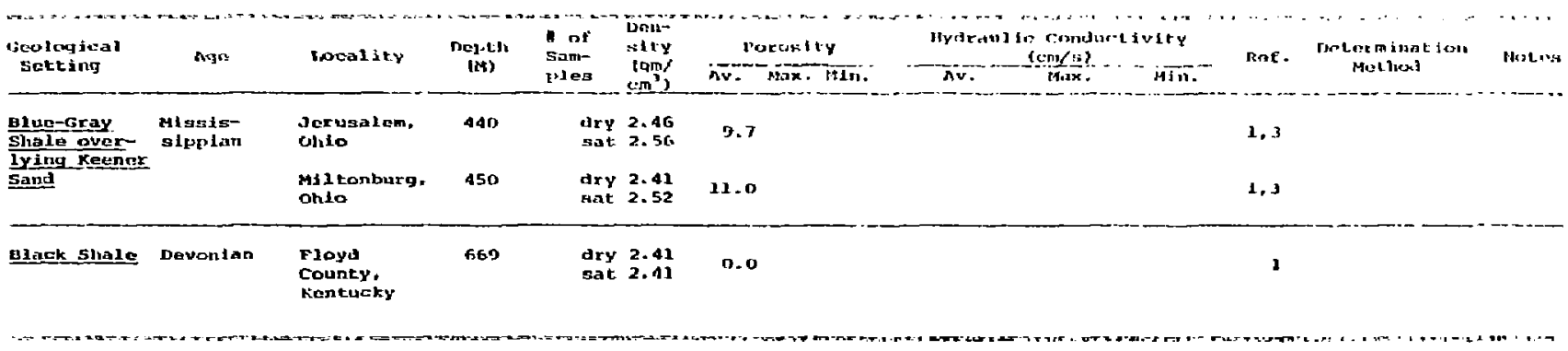


Purryow $y$ (cont:inuera)

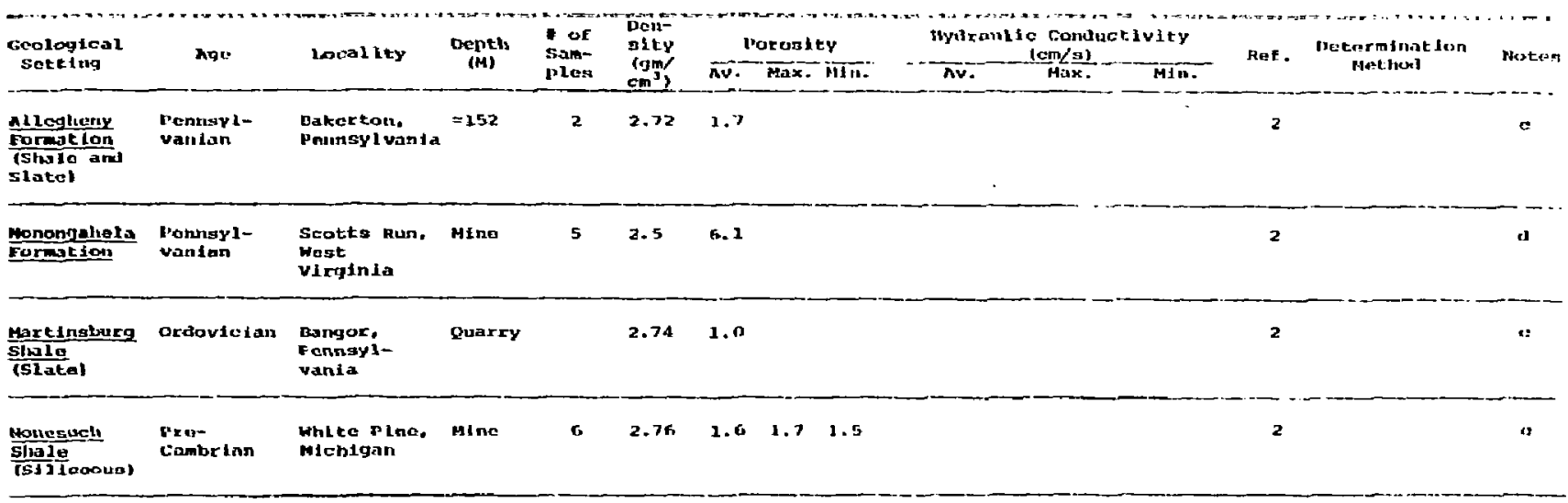

"Effective gorosity.

affectivo parosity. Compressive atrength $11,6000 \mathrm{Mn} / \mathrm{nn}^{2}$. 
REGLOA Y

\begin{tabular}{|c|c|c|c|c|c|c|c|c|c|c|c|c|c|}
\hline \multirow{2}{*}{$\begin{array}{l}\text { Geological } \\
\text { Setting }\end{array}$} & \multirow{2}{*}{ Ago } & \multirow{2}{*}{ Locallty } & \multirow{2}{*}{$\begin{array}{l}\text { Depth } \\
\text { (H) }\end{array}$} & \multirow{2}{*}{$\begin{array}{l}\text { iof } \\
\text { Sant } \\
\text { ples }\end{array}$} & \multirow{2}{*}{$\begin{array}{l}\text { Don- } \\
\text { sity } \\
\operatorname{lom}^{2} \sin ^{2}\end{array}$} & \multicolumn{3}{|c|}{ Parosity } & \multicolumn{2}{|c|}{$\begin{array}{c}\text { Hydraul1e confuct luity } \\
(\mathrm{cm} / \theta)\end{array}$} & \multirow{2}{*}{ Ref. } & \multirow{2}{*}{$\begin{array}{c}\text { Detarminntion } \\
\text { Muthed }\end{array}$} & \multirow{2}{*}{ Nores } \\
\hline & & & & & & Av. & Max. & Min. & Mnx. & $\sin$. & & & \\
\hline 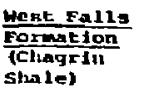 & $\begin{array}{l}\text { Upernx } \\
\text { Levandan }\end{array}$ & $\begin{array}{l}\text { Lincoln } \\
\text { county. } \\
\text { woot } y \text { irgint }\end{array}$ & & & & 2,5 & & & & & 4 & $\begin{array}{l}\text { From } 230 \\
\text { matrix and } \\
\text { hulk dennjty } \\
\text { moasuremnnt. }\end{array}$ & a \\
\hline \multirow[t]{2}{*}{$\begin{array}{l}\text { Chaltanooga } \\
\text { Silu1s }\end{array}$} & $\begin{array}{l}\text { Devonian } \\
\text { and Mis- } \\
\text { sisglplan }\end{array}$ & $\begin{array}{l}\text { Irvino } \\
\text { Fleid. } \\
\text { Kentucky }\end{array}$ & $\begin{array}{l}\text { sub- } \\
\text { surface }\end{array}$ & 2 & 2.38 & 7.5 & 7.6 & 7.1 & & & 2 & & b \\
\hline & & $\begin{array}{l}\text { Hear } \\
\text { Smithille. } \\
\text { Tennegued }\end{array}$ & Mino & 2 & 2.53 & 1.7 & 1.7 & 1.76 & & & 2 & & c \\
\hline
\end{tabular}

a1250 ft. coro, overall avorago.

Eefective porosity. 
REGION v

OTHER PROPERTIES

\begin{tabular}{|c|c|c|c|c|}
\hline Formation & Age & Iocality & $\begin{array}{c}\text { Resiativity } \\
\text { (ohm-cm) }\end{array}$ & Reference \\
\hline$\frac{\text { Honesuch Shale }}{\text { (Siliceous) }}$ & $\begin{array}{l}\text { Pre- } \\
\text { Cambrian }\end{array}$ & $\begin{array}{l}\text { White Pine, } \\
\text { Michigan }\end{array}$ & $10^{4}$ & 1 \\
\hline Shale & $?$ & $\begin{array}{l}\text { Shamokin, } \\
\text { Pennsylva.ila }\end{array}$ & $10^{5}$ & 1 \\
\hline
\end{tabular}


REGION $\mathbf{v}$

REFERENCES

1. Bìch, F.: Schairer, J. R., and Spicer, C. H., 1942, Handbook of Physical Constants: Geological Society of America, Special Paper No. 36, 325 p.

2. Manger, E. G., 1963, Porosity and Bulk Density of Sedimentary Rocks: 0 . j- Geological Surver Bulletin 1244-E, $55 \mathrm{p}$.

3. Melcher, A. F., 1921. Determination of Pore Space of oil and Gas Sands: Trans. Am. Inst. Min. Eng., v. 65, PP. 480-489.

4. Nuhfer, E. G., and Vinopal, R. J., 1978, Nature of Porosity in Upper Devonian shales of Lincoln County, West virginia: Geol. Soc. Amer. Abst. Programs, v. 10, no. 7, $p .464$. 
REGION 6: THE ATLANTIC COASTAL PLAIN AND THE TRIASSIC BASIN

The east coast of the United states is a transitional zone between the Appalachian region and the Atlantic Ocean. Its geology contains a record of Mesozoic sea-floor spreading and also presents some analogies with the GuIf coast. Early stages of spreading are indicated by the Triassic Basins of the Appalachians (which contain Brunswick shale) and later stages are found along the coastal plains to the east. A Cretaceous shale (Middendorf) is found in this second zone.

Structural relationships between the various units are shown in Figs. 15 and 16. 

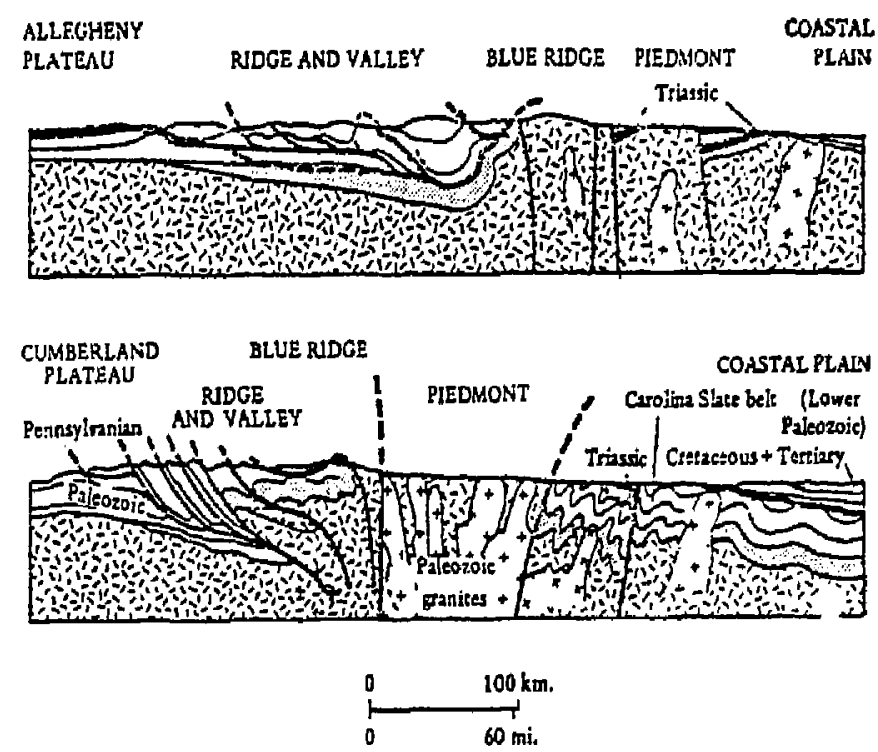

Figure 15: Generalized structural sections across the Appalachians and the Atlantic Coastal Plain (From Mint2, 1977)

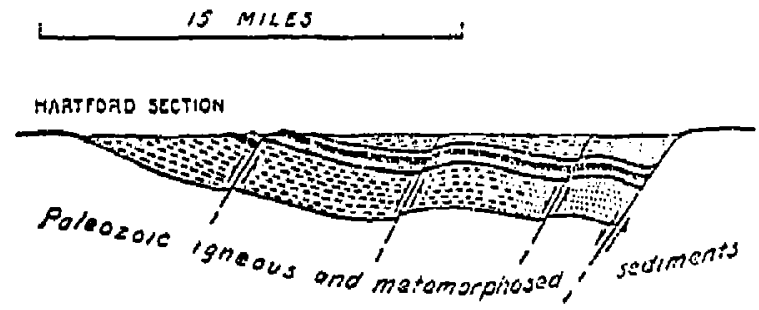

Figure 16: Section showing detailed structure of a Triassic Basic (From Eardley, 1962) 
TABIE 4-6 GENERAIIZED STRATIGRAPHIC COLUMN FOR NEW JERSEY (ATIANTIC COASTAL PLATN)

[From schuchert (1943)]

Nore: Units described in the hydrologie tableg are prezeded by *.

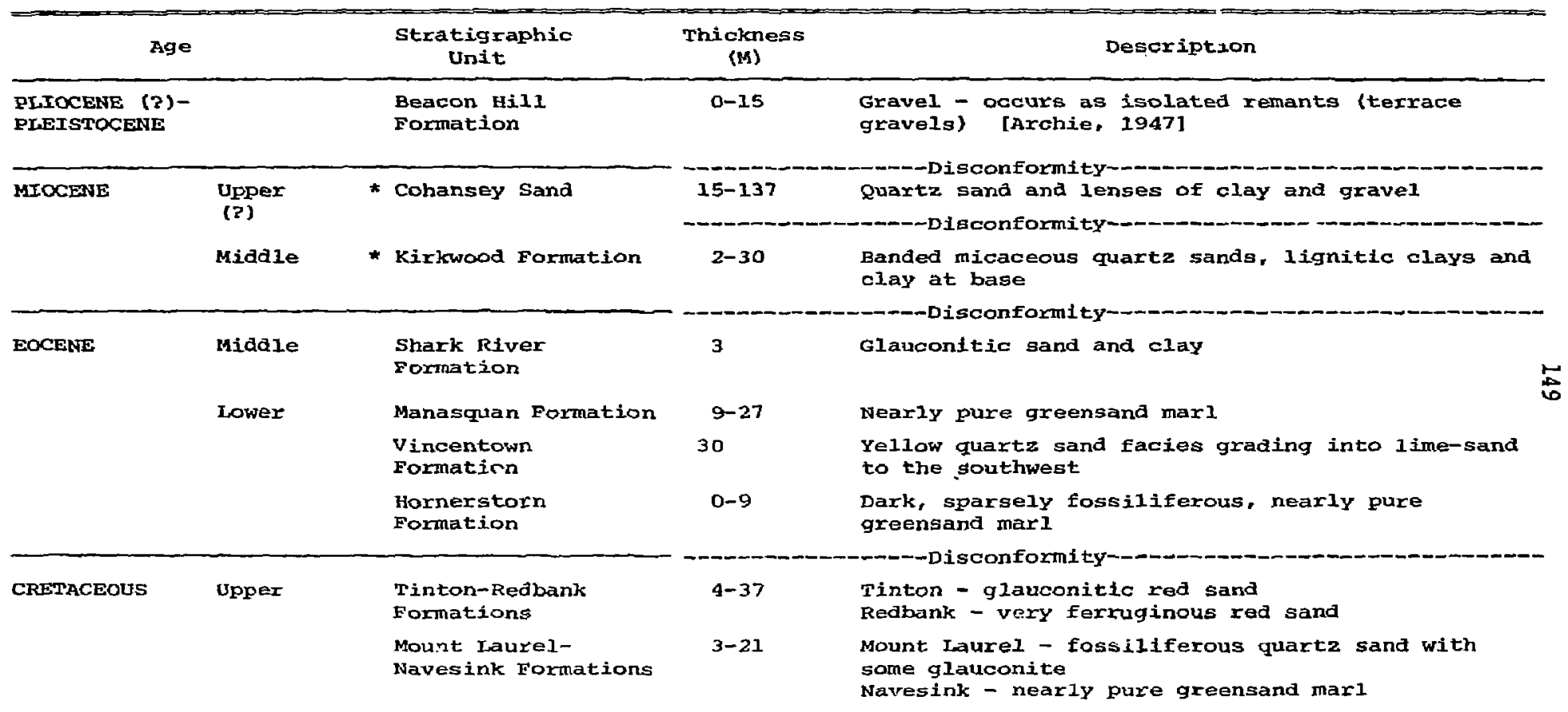


TABIE 4-6 (Continued)

\begin{tabular}{|c|c|c|c|c|c|}
\hline A & & & $\begin{array}{c}\text { Stratigraphic } \\
\text { Unit }\end{array}$ & $\begin{array}{l}\text { Thickness } \\
\text { (M) }\end{array}$ & Description \\
\hline \multirow[t]{5}{*}{ CRETACEOUS } & \multirow[t]{5}{*}{ Upper } & \multicolumn{2}{|r|}{$\begin{array}{l}\text { Wenonah- } \\
\text { Marshalltown } \\
\text { Formations }\end{array}$} & $1.5-43$ & $\begin{array}{l}\text { Wenonah - black to redaish brown sand sometimes } \\
\text { strongly micaceous, with small amounts of glauconite } \\
\text { Marshalltcwn - sandy clay to clayey greensand and } \\
\text { marl, or laminated micaceous clay or pure greensand } \\
\text { marl }\end{array}$ \\
\hline & & \multicolumn{2}{|r|}{ Englishtown Sand } & $0-30$ & Quartz sand \\
\hline & & \multicolumn{2}{|r|}{$\begin{array}{l}\text { Woodbury clay } \\
\text { Merchantille clay } \\
\text { Marl }\end{array}$} & $\begin{array}{l}15 \\
11-18\end{array}$ & $\begin{array}{l}\text { Black, somewhat micaceous and slightly sandy clay } \\
\text { Black, glauconitic, somewhat sandy clay marl }\end{array}$ \\
\hline & & & $\begin{array}{l}\text { Magothy Formation } \\
\text { (Middendorf } \\
\text { Formation - South } \\
\text { Carolina) }\end{array}$ & $\begin{array}{r}3-53 \\
30-60\end{array}$ & $\begin{array}{l}\text { Magothy - clay, white sand, with seams of black } \\
\text { lignite and thin beds of black clay } \\
\text { Middendorf - Partly correlative with Magothy in } \\
\text { New Jersey. Dark laminated clay and micaceous } \\
\text { sand. [AIchie, 1947] }\end{array}$ \\
\hline & & & Raritan Formation & $46-152$ & Variable and variegated sands and plastic clays \\
\hline \multirow[t]{4}{*}{ TRIASSIC } & Upper & \multicolumn{2}{|r|}{ NEWARK GROUP } & & \\
\hline & & \multicolumn{2}{|r|}{ * Brunswick Shale } & $\begin{array}{c}1,524-3,658 \\
91-366\end{array}$ & $\begin{array}{l}\text { Red shale and sandstone } \\
\text { Basalt flows }\end{array}$ \\
\hline & & \multicolumn{2}{|r|}{$\begin{array}{l}\text { Watchung Basalt } \\
\text { Lookatong } \\
\text { Formation }\end{array}$} & $518-1,097$ & $\begin{array}{l}\text { Black shale, dark argillite, flagstone, and rare } \\
\text { thin limestone }\end{array}$ \\
\hline & & \multicolumn{2}{|r|}{ stockton Formation } & $702-945$ & $\begin{array}{l}\text { Arkosic sandstone, conglomerate and red shale } \\
\text { (lies on Precambrian) }\end{array}$ \\
\hline
\end{tabular}

PAIEOZOIC BASEMENT [See Table 3-5.] 
IYYDROLOGIE BAIA

ATLANTLC DIAIN AND TRIASSIC: BASINE

\begin{tabular}{|c|c|c|c|c|c|c|c|c|c|c|c|}
\hline \multirow{2}{*}{$\begin{array}{l}\text { Geologlcal } \\
\text { Setting }\end{array}$} & \multirow{2}{*}{ Mye } & \multirow{2}{*}{ locality } & \multirow{2}{*}{$\begin{array}{l}\text { neitkh } \\
\text { (M) }\end{array}$} & \multirow{2}{*}{$\begin{array}{l}\text { Haf } \\
\text { sam- } \\
\text { ples }\end{array}$} & \multirow{2}{*}{ 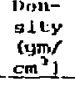 } & Parosity & \multicolumn{2}{|c|}{ Iydranlite Conduetivity } & \multirow{2}{*}{ ReE. } & \multirow{2}{*}{$\begin{array}{l}\text { Potermination } \\
\text { metiod }\end{array}$} & \multirow{2}{*}{ Noten } \\
\hline & & & & & & Ru. Hax. Min. & Av. & 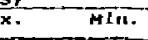 & & & \\
\hline \multirow[t]{8}{*}{ 브르 C13X. } & Mincene & $\begin{array}{l}\text { Salishury, } \\
\text { Maryland }\end{array}$ & & & & $\begin{array}{l}\text { Consod delation } \\
\text { loind }\left(\mathrm{kig} / \mathrm{cm}^{2}\right) \\
\end{array}$ & $\begin{array}{c}\text { From } \\
\text { cousgolidetson }\end{array}$ & $\begin{array}{c}\text { Constant } \\
\text { Flow } \\
\end{array}$ & 3 & I.ah. & \\
\hline & & & 23.7 & $\mathbf{x}$ & & A & $\begin{array}{l}5.3 \times 10^{-7} \\
1.5 \times 10^{-7}\end{array}$ & $\begin{array}{l}5.8 \times 10^{-7} \\
6.7 \times 10^{-8}\end{array}$ & & & 3 \\
\hline & & & 23.6 & 1 & & 4 & $\begin{array}{l}4-2 \times 10^{-7} \\
2.7 \times 10^{-2}\end{array}$ & $\begin{array}{l}1.3 \times 10^{-7} \\
5.5 \times 10^{-9}\end{array}$ & & & $b$ \\
\hline & & & 24.4 & $\mathbf{1}$ & & i & $\begin{array}{l}6.4 \times 10^{-7} \\
3.5 \times 10^{-7}\end{array}$ & $\begin{array}{l}2.2 \times 10^{-6} \\
5 \times 10^{-7}\end{array}$ & & & $c$ \\
\hline & & & 24.2 & 1 & & A & $\begin{array}{l}1.9 \times 10^{-7} \\
1.5 \times 10^{-7}\end{array}$ & $\begin{array}{l}9.1 \times 10^{-7} \\
5.5 \times 10^{-7}\end{array}$ & & & A \\
\hline & & & 23.1 & 1 & & a & $\begin{array}{l}2.5 \times 10^{-7} \\
6 \times 10^{-61}\end{array}$ & $\begin{array}{l}1.5 \times 10^{-9} \\
1 \times 10^{-8}\end{array}$ & & & n \\
\hline & & & 24.7 & 1 & & 4 & $\begin{array}{l}1.0 \times 10^{-7} \\
1.4 \times 10^{-7}\end{array}$ & $\begin{array}{l}1.1 \times 10^{-7} \\
4.2 \times 10^{-6}\end{array}$ & & & r \\
\hline & & & 25 & 1 & & 4 & $\begin{array}{l}1.4 \times 10^{-7} \\
3.0 \times 10^{-8}\end{array}$ & $\begin{array}{l}4.2 \times 10^{-8} \\
1.8 \times 10^{-a}\end{array}$ & & & 丁 \\
\hline
\end{tabular}


MH:itofl VT (contLmaod)

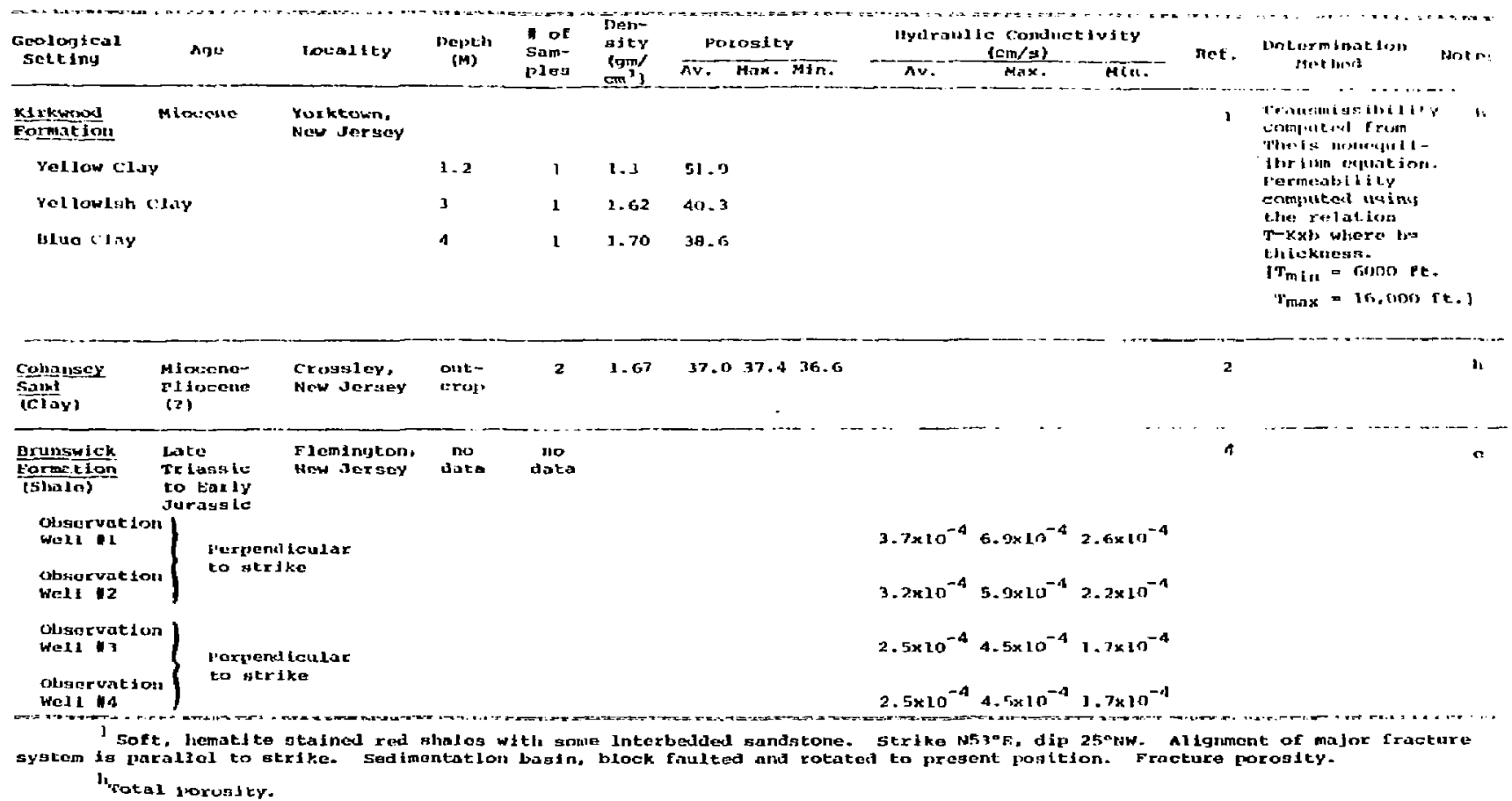


Hegrous ve (Continued!

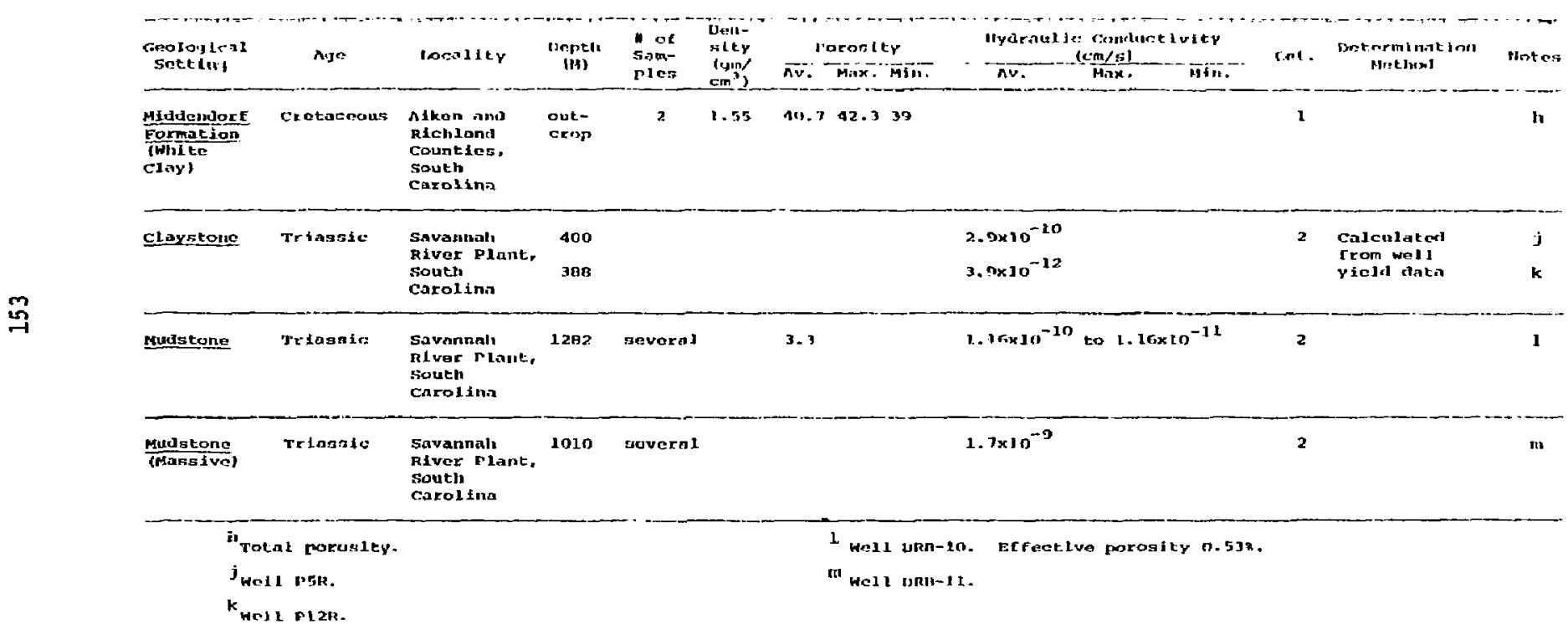


REGION VI

OTHER PROPERTIES

\begin{tabular}{|c|c|c|c|c|}
\hline & $\begin{array}{c}\text { Consolidation Load } \\
\left(\mathrm{Kg} / \mathrm{cm}^{2}\right)\end{array}$ & $\begin{array}{l}\text { Diffusivity } \\
\left(\mathrm{cm}^{2} / \mathrm{sec}\right)\end{array}$ & $\begin{array}{l}\text { Determination } \\
\text { Method }\end{array}$ & Reference \\
\hline $\begin{array}{l}\text { Blue Clay - Miocene, } \\
\text { Salisbury, Maxyland }\end{array}$ & 4 & $2.3 \times 10^{-2}$ & & \\
\hline Sample C-2 & 8 & $1.7 \times 10^{-2}$ & & \\
\hline Sample c-7 & $\begin{array}{l}4 \\
8\end{array}$ & $\begin{array}{l}1.3 \times 10^{-2} \\
1.9 \times 10^{-2}\end{array}$ & & \\
\hline Sample $\mathrm{C}-8$ & $\begin{array}{l}4 \\
8\end{array}$ & $\begin{array}{l}2.9 \times 10^{-2} \\
2.5 \times 10^{-2}\end{array}$ & & \\
\hline Sample C-9 & $\begin{array}{l}4 \\
8\end{array}$ & $\begin{array}{l}2.3 \times 10^{-2} \\
2.0 \times 10^{-2}\end{array}$ & Lab & 3 \\
\hline Sample C-11 & $\begin{array}{l}4 \\
8\end{array}$ & $\begin{array}{l}1.4 \times 10^{-2} \\
5.3 \times 10^{-3}\end{array}$ & & \\
\hline Sample C-12 & $\begin{array}{l}4 \\
8\end{array}$ & $\begin{array}{l}2.0 \times 10^{-2} \\
1.8 \times 10^{-2}\end{array}$ & & \\
\hline Sample C-14 & $\begin{array}{l}4 \\
8\end{array}$ & $\begin{array}{l}5.0 \times 10^{-3} \\
1.8 \times 10^{-3}\end{array}$ & & \\
\hline
\end{tabular}




\section{REGION VI}

REFERENCES

1. Manger, E. G.. 1963, Porosity and BuIk Density of Sedimentary Racks: U. S. Geological Survey Bulletin 1144-E, $55 \mathrm{p}$.

2. Marine, I. Wendell, 1963, Geohydrology of Burled Triassic Basin at Savannah River elant, South Carolina: in Underground waste Management and Artificial Recharge, 2nd International Symposium, New orleans, Ia., American Assoclation of Petroleum Geologigts. v. 1, PP. 4BIr 504.

3. Wolf: R. G.. 1970, Field and Laboratory Determination of the Hydraulic Diffusivity of a Confining Bed: Water Resources Research, v. 6, no. 1, pp. 194-203.

4. Vecchiolli, J., 1967, Directional Hydrolic Behavior of a Fractured Shale Aquifer in New Jersey, In Hyarology of Fraotured Rocks: Assoc. Int. D'Hyd. Sci., v. I, p. 318-326. 
BIBLIOGRAPHIC REFERENCES

American Geological Institute, 1972, Glossary of Geology, Gary, M., McAfee, R., Wolf, C.L., edit., Washington, D.C.

Archie, G. E., 1950, Introduction to petrophysics of reservoir rocks: Am. Assoc. Petrol. Geol., Bull, V 34, n. 5, p. 943-961.

Aronson, J. L., \& Hower, J., 1976, Mechanism of burial netamorphism of argillaceous sediments: 2 Radiogenic Argon Evidence; Geol. Soc. of Am., Bull. V. 87, p. 738-744.

Atwater, J., 1970, Implication of plate tectonics for the Cenozoic tectonic evolution of western North America, Geol. Soc. of Ain., Bull. 81, p. 3513-3536.

Berry, Fred A. F., 1959, Hydrodynamics and geochemistry of the Jurassic Cretaceous systems in the San Juan Basin, Northwestern New Mexico and Southwest Colorado, Ph.D. thesis, Stanford Univ.

Clark, T. H. \& Stearn, C. W., 1968, Geological Evolution of North America, 2nd Ea., Ronald Press Co. Publ.

Curmings, J. C., Touring, R. M., \& Brabb, E. E., 1962, Geology of the northern Santa Cruz Mountains; Calif. Div. of Mines and Geol., Bull. 181, p. 179-220.

Dickinson, W. R., 1971, Plate tectonic models for orogeny at continental margins, Nature, V. 232 , p. 41-42. 
du Rouchet, 1978, A tentative geomechanical theory of oil migration, Bull. Cent. Rech., Explor., Prod. ELF Aquitaine, Vol. 2, n. 2, p. 337-373.

Eardley, A. J., 1962, Structural geology of North America, Haxper and Row Publ., New York, N.Y., 743 p.

Gill, J. R., Merriwether, E. A., and Cobban, W. A., 1970, Stratigraphy and nomenclature of some Upper Cretaceous and Lower Tertiary rocks in South Central Wyoming, U. S. Geol. Surv. Prof. Pap. 667, 53 p.

Golder Associates, 1977, Development of site suitability criteria for a high level waste repository. A report to Lawrence Livermore Laboratory, UCRL-13793.

Hackel, 0., 1966, Summary of the geology of the Great Vailey: Calif. Div, of Mines and Geol., Bull. 190, p. 217-238.

Harman, C. G., and Fraulini, F., 1940, Properties of kaolin as function of particle size: Am. Ceram. Soc. Jour. v. 23 , p. 252-259.

Hower, J., Es?inger, E. V., Hower, M. E.., and Perry, E. A., 1976, Mechanism of burial metamorphism of argillaceous sediments: 1 Mineralogical and chemical eviolence: Geol. Soc. of Am. Bull. v 87, p. 725-737.

King, P. B., 1951, The Tectonics of Middle North America, East of the Cordilleran System, Princeton Univ. Press, New Jersey, $203 \mathrm{p}$. 
Kirby, J. M., 1943, Upper Cretaceous stratigraphy of the west side of the Sacramento Valley, South of Willows, Glen County, California, Am. Assoc. Petr. Geol., Bull. v. 27 , p. $270-305$.

Lee, W. T., 1927, Correlation $0^{\circ}$ geologic formations between east central colorado, central Wyoming, and southern Montana, U.S. Geol, Surv. Prof, Pap. 149, 80 p.

Levorsen, A. I., 1967, Geology of Petroleun, 2nd Ed., W. H. Freeman \& Co. Publ., San Francisco, 724 p.

Magara, K., 1973, Compaction and fluid migration in Cretaceous shales of western Canada: Geol. Surv. of Canada, Pap. $72,18,64$ p.

Maher, J. C., Carter, R. D., and Gantz, R. J., 1975, Petroleum geology of naval petroleum reserve No. 1, Elk Hills, Kein County, Califnrnia: J.s. Geol. Surv. Prof. Pap. 912, $109 \mathrm{p}$.

Maxwe11, D. T., and Hower, 1967, High grade diagenesis and low grade metamorphism of illite in the Precambrian Belt Series: Am. Mineralogist, v. 52, p. 843-857.

Maxwell, J. C., 1962, Origin of slaty and fracture cleavage in the Delaware Water Gap area, New Jersey and Pennsylvania: in Petrologic Studies (Buddington Volume), Geol. Soc. of Am. , p. 281-311.

Mielenz, R. C., and King, M. E., 1955, Physical chemical properties and engineering performances of clays: Calif. Div. of Mines and Geol. Bull. 169: Clays and Clay Technology: p. 196-254. 
Hintz, L. W., 1977, Historical Geology: The Science of a Dynamic Earth; Merrill Publ. Co., Columbus, Ohio, 588 g.

Murray, G. E., 1961, Geology of the Atlantic and Gulf Coastal Provinces of North America, Harper Bros., New York, N.Y., 692 pp.

Osborne, H. W., 1953, Symposium on fractured reservoirs. Discussion: Am. Assoc. Petr. Geol. Bull. v. 37, p. 318.

Page, B. M., 1966, Geology of the C-ast Ranges of California: Calif. Div. of Mines Geol. Bull, 190, p. 255-276.

Poole, F. G., and Sandberg, C. A., 1977, Silurian and Devonian paleography: in Paleozoic Paleogeography, soc. Econ. Paleont. and Mines, Stewart, J.H., Stevens, C. H., ana Fritsche, M. E., Ed. Pacific Coast Paleogeography Symposium 1, p. 39-85

Powers, H. C., 1967, Fluid release mechanisms in compacting marine mud rocks and their importance in oil exploration: Am. Assoc. Petr. Geol., Vol. 51, p. 1240-1253.

Rubey, W. W., and Hubbert, M. B., 1959, Role of fluid pressure in mechanics of overthrust faulting: Am. Assoc. Petr. Geol., Bull. v. 70, n. 2, p. 167-184.

Ruedemann, P., 1939, Geology of the south central lowlands and Ouachita Province: in Geology of North America, Ruedemann, P. and Belk, E., Edit., Verlay von Gebrldier Borntraegen, Berlin, p. 463-518. 
Samuels, S. G., 1950, The effect of base exchange on the engineering properties of soils. Figure in llielenz and King (1955) op. cit.

Schuchert, C., 1943, Stratigraphy of the Eastern and Central United States; John Filey and Sons, Inc. Publ., New York, N.Y., 1013 p.

Seyfert, C. K. and Sirkin, I. A., 1973, Earth history and plate tectonics, Harper and Row Publ., New York, N.Y.

Smith, J. E., 1971, The dynamics of shale compaction and evolution of pore fiuid pressures, Mathem. Geol., vol. 3, no. 3 , p. $239-263$.

Smith, J. E., 1973, Shale compaction, Soc. of Econ. Petr. Eng. , v. 255, p. 11-24.

Snow, T. D., 1968: Rock fracture spacings, openings. and porosities: Jour. of Soil Mech., Foundation Divisions Proceeding. Am. Soc. Civ. Eng., V. 94, p. 73-91.

Stewart, J. H., and Suczek, C. A., 1977, Cambrian and latest Erecambrian palr jgeography: Paleozoic Paleogeography; Pacific Coast Paleogeography Symposium, n. 7, Soc. Econ. Pal. and Mines, Stewart, J. H., Stevens, C. H., and Fritsche, H. E., Edit., p. 1-19.

Tourtelot, M. A., 1962, Preliminary Investigation of the geologic setting of the Pierre shales, Great Plains region; U. S. Geol. Surv., Prof. Pap. 390, 74 p. 
Towe, K. M., 1962, Diagenesis of clay minerals as a possible source of cement in sedimentary rocks:

Jour, of seâ. Petré sgy, v. 32, p. 26-28.

Weaver, C. E., 1959, The clay petrology of sediments:

in Clay and Clay Minerals, v. 6, p. 154-187.

Weaver, C. E., and pollard, E., 1975, The chemistry of clay minerals, Elsevier scient. Publ. Co., New York, N.Y., 213 p.

Webster, D. S., Proctor, J. F., and Marine, I. W., 1970, Two-well tracer test in fractured crystalling rock. U.S. Geol. Surv., Wat. Supp. Pap. 1544-I.

Yeh, H. W., and Savin, S. M., 1977, Mechanism of burial metamorphism of argillaceulus sediments: 3-0-Isotope evidence: Geol. Soc. of Am. Bu11. 88, p. 1321-1330.

NOTICE

This report was prepared as an account of work sponsored by an agency of the United States Government. Neither the United States Government nor any agency thereof, or any of their employees, makes any warranty, expressed or imilied, or assumes any legal liability or responsibility for any third party's use, or the results of such use, of any information apparatus, product or process disclosed in this report, or represents that its use by such third party would not infringe privately owned rights.

Reference to a company or product name does not imply approval or recommendation of the product by the University of California or any U.S. Government agency to the exclusion of others that may be suitable. 